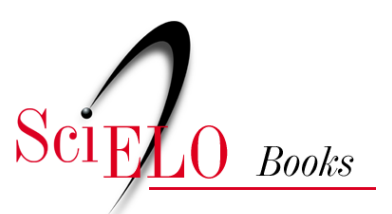

\title{
Construção social da aprendizagem em saúde mental e saúde da família
}

\author{
Rozemere Cardoso de Souza \\ Josenaide Engracia dos Santos
}

SOUZA, RC., and SANTOS, JE., orgs. Construção social da aprendizagem em saúde mental e saúde da família [online]. Ilhéus, BA: Editus, 2014, 216 p. ISBN 978-85-7455-447-1. Available from SciELO Books <http://books.scielo.org $>$.

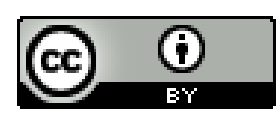

All the contents of this work, except where otherwise noted, is licensed under a Creative Commons Attribution 4.0 International license.

Todo o conteúdo deste trabalho, exceto quando houver ressalva, é publicado sob a licença Creative Commons Atribição 4.0.

Todo el contenido de esta obra, excepto donde se indique lo contrario, está bajo licencia de la licencia Creative Commons Reconocimento 4.0. 


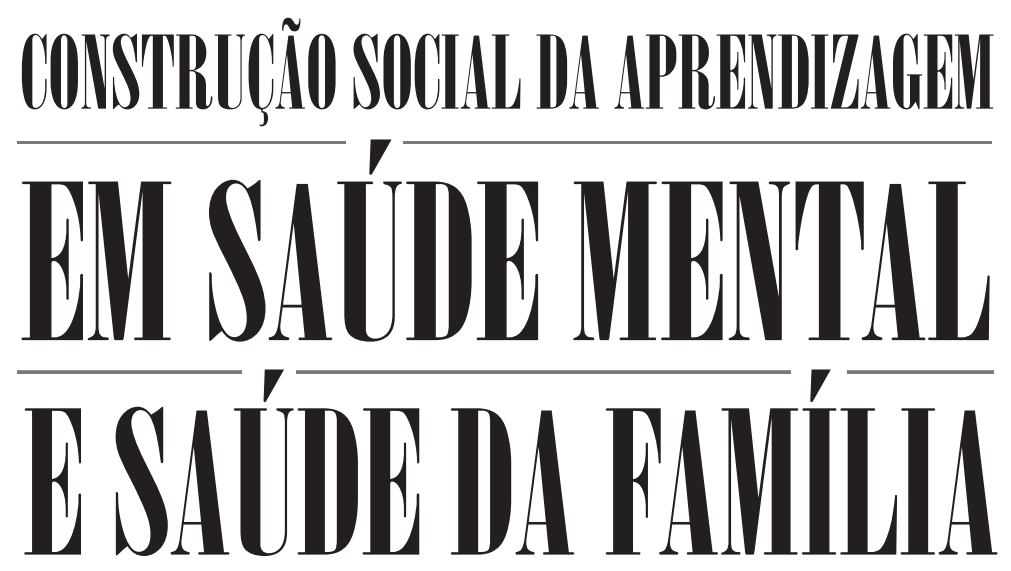




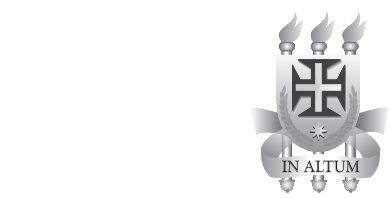

Universidade Estadual de Santa Cruz

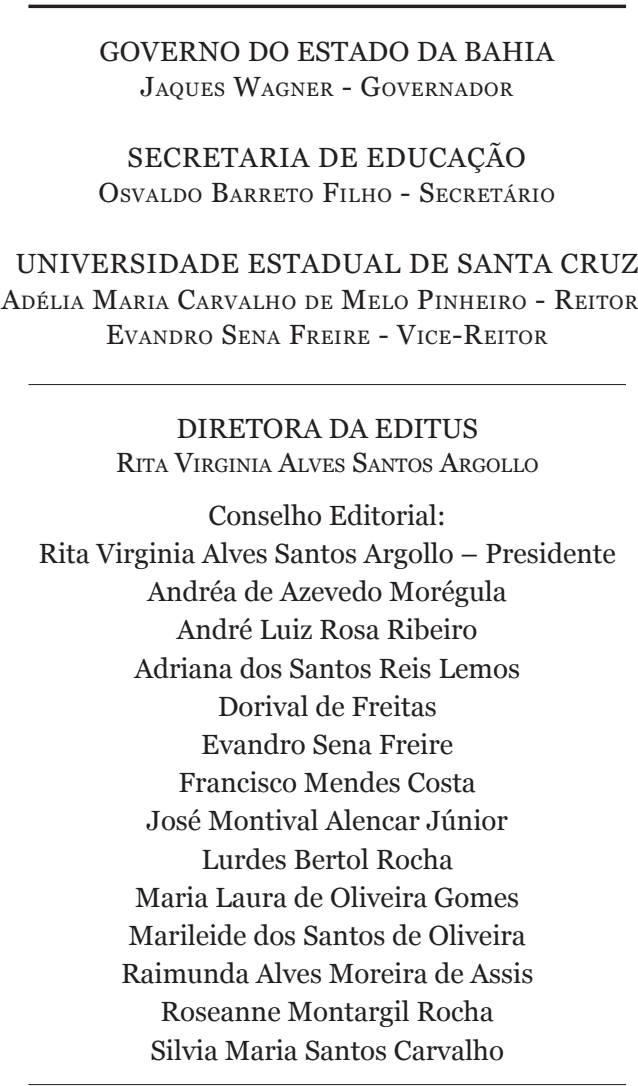




\section{Rozemere Carrdoso de Souza Josenaide Engracia dos Santos

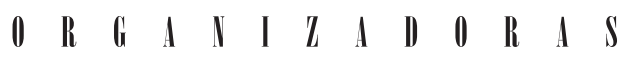

\section{COISTRICİ̃O SOCLLL DI IPREIDILLGEEII}

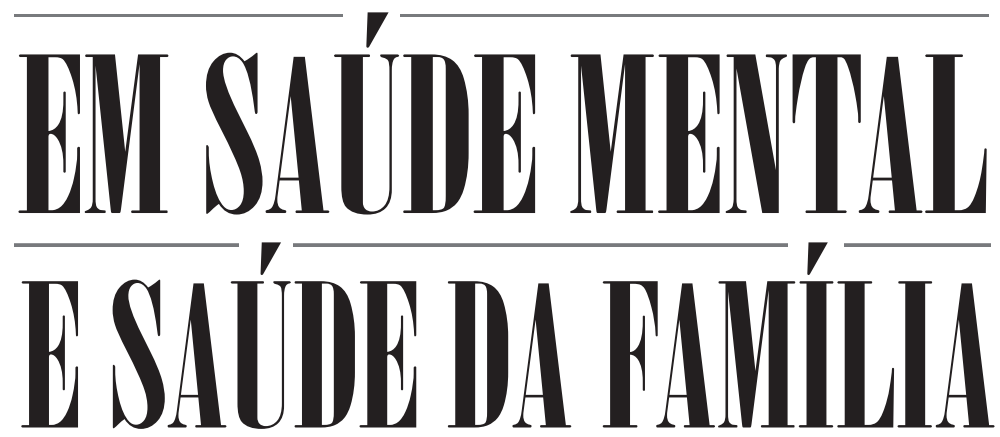

Débora Cristiane Silva Flores Lino - Erika Antunes Vasconcellos George Amaral Santos • João Mendes de Lima Júnior Laura Regia Oliveira Cordeiro • Luís Fernando Tófoli

Nairan Morais Caldas • Viviane dos Santos Souza

Apoio financeiro:

\section{fapesb}

Fundação de Amparo

à Pesquisa do Estado da Bahia

\section{Illiélls- Piallitil}

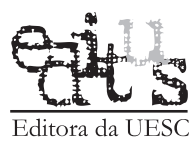

2011 


\section{Direitos desta edição reservados à} EDITUS - EDITORA DA UESC

A reprodução não autorizada desta publicação, por qualquer meio, seja total ou parcial, constitui violação da Lei no ${ }^{0}$ 9.610/98.

Depósito legal na Biblioteca Nacional, conforme Lei no ${ }^{0}$ 10.994, de 14 de dezembro de 2004.

\section{PROJETO GRÁFICO E CAPA \\ Marcel Santos}

FINALIZAÇÃO

Alencar Júnior

REVISÃO

Genebaldo Pinto Ribeiro

Paulo Roberto Alves dos Santos

Roberto Santos de Carvalho

Dados Internacionais de Catalogação na Publicação (CIP)

C756 Construção social da aprendizagem em saúde mental e
saúde da família / Rozemere Cardoso de Souza,
Josenaide Engracia dos Santos, organizadoras ;
Débora Cristiane Silva Flores Lino ... [et al.]. - Ilhéus,
BA : Editus, 2014.
216 p.
Inclui referências.
ISBN: 978-85-7455-350-4
1. Psicologia social. 2. Serviços de saúde mental.
3. Família - Saúde e higiene. 4. Aprendizagem. 5.
Ensino. 6. Enfermagem Psiquiátrica. I. Souza, Rozemere
Cardoso de. II. Santos, Josenaide Engracia dos. III. Lino,
Débora Cristiane Silva Flores.
CDD 302

\section{EDITUS - EDITORA DA UESC}

Universidade Estadual de Santa Cruz

Rodovia Jorge Amado, km 16 - 45662-90o - Ilhéus, Bahia, Brasil

Tel.: (73) 3680-5028

www.uesc.br/editora

editus@uesc.br

EDITORA FILIADA À

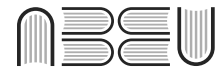

Associação Brasileira

das Editoras Universitárias 


\section{Alltores}

\section{Débora Cristiane Silva Flores Lino}

Psicóloga. Mestranda em Enfermagem e Saúde pela Universidade Estadual do Sudoeste da Bahia (Uesb), Especialista em Psicologia Social e em Saúde Mental pela Universidade Estadual de Santa Cruz (Uesc), Ilhéus, Bahia. Membro do Grupo de Pesquisa em Saúde Mental da Uesc.

\section{Erika Antunes Vasconcellos}

Psicóloga. Doutora em Ciências Médicas na área da Saúde Mental pela Faculdade de Ciências Médicas da Universidade Estadual de Campinas (FCM/Unicamp). Professora adjunta da Uesc, Ilhéus, Bahia. Líder do Grupo de Pesquisa em Saúde Mental da Uesc.

\section{George Amaral Santos}

Enfermeiro. Mestrando em Saúde Coletiva pelo Instituto de Saúde Coletiva da Universidade Federal da Bahia (ISC/ UFBA), Salvador, Bahia. Especialista em Saúde Coletiva com área de concentração em Saúde Mental. Membro do Grupo de Pesquisa em Saúde Mental da Uesc e do Grupo de Estudos sobre a Universidade Brasileira ISC/UFBA.

\section{João Mendes de Lima Júnior}

Psicólogo. Mestre em Letras, com interface em Linguística e Psicanálise. Professor assistente da Universidade Federal do Recôncavo da Bahia (UFRB), Santo Antônio de Jesus, Bahia.

\section{Josenaide Engracia dos Santos}

Terapeuta Ocupacional. Psicóloga. Doutora em Ciências Sociais pela UFBA. Professora da Universidade de Brasília (UNB), Brasília, Distrito Federal. Professora Colaboradora do Núcleo de Saúde Mental do Programa de Residência 
Multiprofissional em Saúde da Universidade do Estado da Bahia (Uneb), Salvador, Bahia. Membro do Grupo de Pesquisa em Saúde Mental da Uesc.

\section{Laura Regia Oliveira Cordeiro}

Médica. Ex-bolsista do Programa de Iniciação Científica da Uesc vinculado à Fundação de Amparo à Pesquisa do Estado da Bahia (Fapesb). Membro do Grupo de Pesquisa em Saúde Mental da Uesc.

\section{Luís Fernando Tófoli}

Médico Psiquiatra. Professor adjunto do Curso de Medicina e do Programa de Pós-Graduação em Saúde da Família, do campus de Sobral, da Universidade Federal do Ceará.

\section{Nairan Morais Caldas}

Enfermeira. Mestre em Enfermagem pela UFBA. Especialista em Enfermagem Psiquiátrica pela Escola de Enfermagem de Ribeirão Preto da Universidade de São Paulo (EERP/USP). Professora assistente da Uesc, Ilhéus, Bahia. Membro do Grupo de Pesquisa em Saúde Mental da Uesc.

\section{Rozemere Cardoso de Souza}

Enfermeira. Doutora em Enfermagem Psiquiátrica pela EERP/USP. Professora titular da Uesc, Ilhéus, Bahia. Líder do Grupo de Pesquisa em Saúde Mental da Uesc.

\section{Viviane dos Santos Souza}

Enfermeira. Mestre em Enfermagem e Saúde pela Uesb. Especialista em Saúde Mental pela Uesc. Professora assistente da Uesc. Membro do Grupo de Pesquisa em Saúde Mental da Uesc e do Grupo de Estudos e Pesquisa em Saúde Mental: Loucos por Cidadania da Uesb. 


\section{lgpiadecimentos}

A Deus, pela inspiração e sabedoria na trajetória do compartilhamento de saberes, de práticas, de afetos e do desejo de avançar frente às adversidades do cotidiano.

Às Secretarias Municipais de Saúde e Instituições de Ensino Superior (IES) públicas dos municípios de Ilhéus, Salvador, Jequié, Vitória da Conquista e Feira de Santana, Bahia, pela oportunidade de desenvolver o estudo nos respectivos contextos de trabalho da Estratégia de Saúde da Família e do ensino de graduação dos cursos de Enfermagem e Medicina.

Às Equipes de Saúde da Família, pela confiança em compartilhar aprendizados do cotidiano de trabalho e de "si mesmos", na luta por uma atenção à saúde mais digna às populações assistidas e, também, por melhores condições de vida e de trabalho no setor.

Aos docentes das Instituições de Ensino Superior (IES) pela confiança e descobertas sobre as práticas de ensino que rompem com o habitual e inovam cenários, saberes e práticas no campo da saúde mental.

À Universidade Estadual de Santa Cruz (Uesc) e à Fundação de Amparo à Pesquisa do Estado da Bahia (Fapesb), pelo apoio e fomento à pesquisa de origem desta obra.

A todos os outros, colegas, amigos, estudantes, pessoas do cotidiano com quem construímos a possibilidade permanente de aprender e de ser melhor. 


\section{Prefíácio}

\section{Luís Ferninndo Tóóli}

Após refletir por algum tempo sobre o convite feito para prefaciar Construção social da aprendizagem em saúde mental e saúde da famúlia, decidi que a melhor maneira de abrir a obra seria contar um episódio que, apesar de à primeira vista ter pouco a ver com o universo da saúde mental na saúde da família, pode revelar, insuspeitadamente, o maior desafio que é posto dentro deste campo, como eu o entendo.

A história não é minha - é de uma amiga há muito tempo envolvida nos movimentos populares, mas é verdadeira. Ela aconteceu lá pelos idos do início da década de 1980, quando éramos um país em ebulição diante das novas possibilidades que o fim iminente do período do regime autoritário trazia - e que, entre outras inovações, trouxe a conquista do Sistema Único de Saúde.

Conta-se que em visitas feitas pelo educador Paulo Freire ao estado do Ceará, ele se encontrou com frequência com moradores de localidades com altos índices de analfabetismo e dificuldades para o exercício de sua cidadania. Esses encontros eram organizados dentro do modelo freireano conhecido como círculos de cultura. Em um desses círculos, ele foi recebido com certa reverência pelos educandos; afinal de contas, ali chegava um renomado professor que, apesar de nordestino, como eles, era recém-chegado do 
exílio e o inspirador do tal círculo de cultura do qual eles participavam.

Paulo Freire não se fez de rogado e, diante daquela deferência toda, explicou que assim como havia coisas que ele sabia e fazia que eles não sabiam e nem faziam, os membros da comunidade também tinham conhecimentos e práticas que ele não dominava. $\mathrm{O}$ círculo seguiu seu ritmo, e, não depois de muito tempo, o grupo passou a discutir situações do cotidiano recente da comunidade. Alguém, então, fez menção a uma morte que havia acontecido por conta da queda de um "quebrador". Freire (2002, p. 3) interveio: "Eu não disse que tinha coisas que vocês sabiam e eu não? Eu não sei o que é um 'quebrador'. Vocês vão ter que ensinar isso para mim".

E então os educandos ensinaram que "quebrador" era o termo usado para uma escora que suporta a parede de um poço em construção, e que eram frequentes as mortes de cavadores de poço quando esta estrutura cedia, soterrando os trabalhadores.

Paulo Freire, nessa pequena passagem, encarnou, na prática, uma série de máximas sobre o processo de ensino que ele veio a cristalizar, no primeiro capítulo da obra Pedagogia da autonomia em 1996 (FREIRE, 2002, p. 3). Dentre elas, destacam-se: "ensinar exige respeito aos saberes dos educandos", "ensinar exige a corporeificação das palavras pelo exemplo", "ensinar exige risco, aceitação do novo e rejeição a qualquer forma de discriminação".

Ao longo desse capítulo, todas as frases que definem o ato de ensinar, segundo Paulo Freire, estão ligadas, de alguma forma, ao conteúdo ou ao escopo de 
Construção social da aprendizagem em saúde mental e saúde da família. Elas incluem, além das citadas, a valorização da pesquisa, do rigor metodológico, do pensamento crítico, da ética e da estética (ou, como Freire gostava de dizer, "decência e boniteza" (2002, p. 20)) e da ligação entre teoria e prática como apoios fundamentais para o ato de educar.

Por fim, a nona frase de Freire sobre o ensinar - que é, provavelmente, a menos explícita delas - merece ser olhada com mais cuidado dentro do tema que será explorado pelo livro organizado por Rozemere Cardoso de Souza e Josenaide Engracia dos Santos: "Ensinar exige o reconhecimento e a assunção da identidade cultural" (2002, p. 18). Como assim, assunção da identidade cultural? E o que isso tem a ver com saúde mental na atenção primária?

Podemos compreender que o trabalho em saúde configura uma subcultura, ou seja, um universo de códigos e símbolos específicos que são compartilhados somente entre as pessoas que trabalham com saúde. Dentro dessa subcultura existem diversas outras. A saúde mental e a saúde da família são dois campos com características, valores, missões e cotidianos muito peculiares. Alguns desses elementos são bastante sobreponíveis. Como exemplo, podemos citar a importância, para ambas, do conceito de comunidade e da herança histórica advinda da reforma sanitária. Outros pontos, no entanto, são bastante distintos, especialmente aqueles que tocam o trabalho cotidiano nos serviços de saúde mental e nas Equipes de Saúde da Família. Há, portanto, identidades culturais que se apresentam e se ocultam nesse processo. 
É frequente que os profissionais de saúde mental se coloquem e sejam vistos como detentores de um conhecimento específico (e, por vezes, hermético) do qual os profissionais da saúde da família não desfrutariam. É muito tentador, por isso, que profissionais de apoio matricial, núcleos de apoio à saúde da família e outros "mentaleiros" se coloquem no lugar dos 'sabidos'. Relembrar a frase de Paulo Freire sobre identidade cultural é uma das formas de escapar desta tendência quase que natural nas relações entre "especialistas" e "generalistas".

Assim como Paulo Freire fez no círculo de cultura, é necessário estar ciente de que há diversas coisas que o profissional de saúde mental não sabe e que precisará aprender com os profissionais da atenção primária. Aqui, claramente, não se trata de um processo de aprendizagem de mão única, mas, por excelência, de uma troca entre universos que se encontram.

Para isso, portanto, é absolutamente essencial reconhecer e, ao mesmo tempo, assumir a identidade cultural (no caso, os códigos e vicissitudes da saúde mental e da saúde da família) de cada parte envolvi$\mathrm{da}-\mathrm{a}$ sua e a do outro. Apenas na posição de respeito com seu próprio lugar e com o lugar do outro é que as trocas podem se tornar produtivas, renovadoras, transformadoras.

Acredito que este livro tem muito a contribuir neste sentido. Mais do que um texto acadêmico sobre as dificuldades da interlocução entre esses dois universos, ele propõe bases didáticas para buscar e encontrar saídas factíveis para os dilemas que se apresentam neste campo. 
Celebrando, portanto, a força da metáfora como elemento constituinte do processo de ensino-aprendizagem - aliás, um tema que nos é trazido pelo último capítulo de Construção social da aprendizagem em saúde mental e saúde da família - quero encerrar, lembrando que o encontro entre profissionais de saúde mental e da saúde da família não precisa ser visto como uma luta, uma batalha.

Existem desafios, é evidente, mas para superá-los, precisamos estar juntos em uníssono, e não em conflito. Muito melhor que a imagem da peleja é a metáfora da dança a dois. De início, cada lado dessa dança - com seu gingado, suas características corporais, sua história - precisará de um tempo para se acostumar com o jeito do parceiro-dançante. Aos poucos, se houver um componente importantíssimo nesse desafio, que é o prazer da experiência da troca - e que, muitas vezes, precisa ser conquistado - os corpos se entendem e geram a harmonia da dança em um só ritmo. É na busca desse ritmo que damos, recebemos e podemos construir saberes fronteiriços e transformadores. Não percamos o ritmo da dança, portanto.

Chegou a hora de começar a ler o livro.

\section{Referência}

FREIRE, P. Pedagogia da autonomia. Saberes necessários à prática educativa. 25. ed. São Paulo: Paz e Terra, 2002. 


\section{Silmínirio}

INTRODUÇÃO - Construção social do processo ensino/aprendizagem em saúde mental

Rozemere Cardoso de Souza

Josenaide Engracia dos Santos ............................... 17

CAPÍTULO 1 - Concepções de saúde mental de equipes de saúde da família

Josenaide Engracia dos Santos

Rozemere Cardoso de Souza

Erika Antunes Vasconcellos

CAPÍTULO 2 - Cotidiano de equipes de saúde da família: perturbações por uso de substâncias psicoativas

Josenaide Engracia dos Santos

Rozemere Cardoso de Souza

CAPÍTULO 3 - Recursos existentes, limitações e os desafios para a promoção do cuidado em saúde mental e saúde da família Josenaide Engracia dos Santos Erika Antunes Vasconcellos

CAPÍTULO 4 - Aprendizagem em saúde mental e saúde da família: o contexto das instituições de ensino superior João Mendes de Lima Júnior Nairan Morais Caldas

Débora Cristiane Silva Flores Lino 83 
CAPÍTULO 5 - Demandas de aprendizagem em saúde mental e saúde da família

George Amaral Santos

Rozemere Cardoso de Souza

CAPÍTULO 6 - Estratégias metodológicas para a construção da aprendizagem em saúde mental

Viviane dos Santos Souza

George Amaral Santos

Laura Regia Oliveira Cordeiro

CAPÍTULO 7 - Experiências de ensino/ aprendizagem como produto da pesquisa em saúde mental e saúde da família

Rozemere Cardoso de Souza

Josenaide Engracia dos Santos

Viviane dos Santos Souza

Nairan Morais Caldas 181 

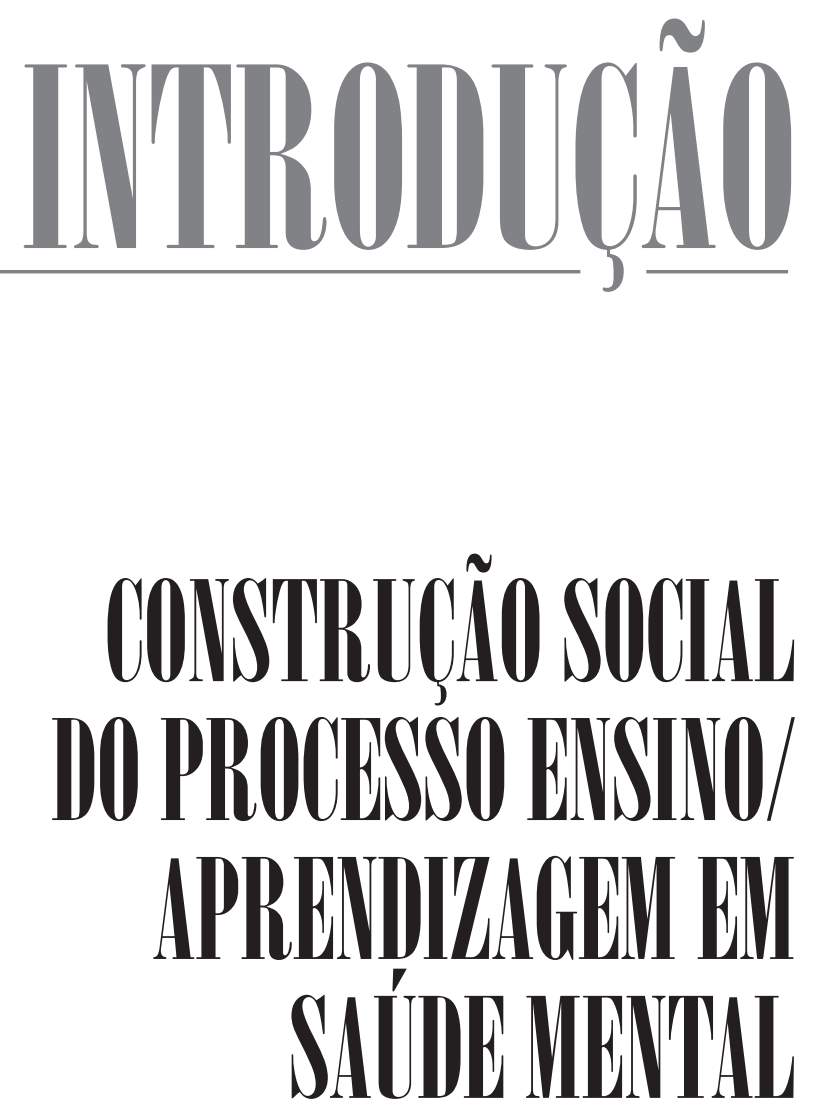

Rozemere Cirloso de Sonza Josenaide Engracia dos Sintos 


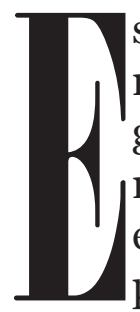

ste trabalho fundamenta-se no construcionismo social, conforme abordagem na Psicologia. Pensar o ensino-aprendizagem em saúde mental, a partir dessa perspectiva, é entender esse processo não como um fenômeno já dado, pronto para exercer suas funções, mas como uma construção que se dá nas trocas sociais em contextos e tempos situados. Um processo de compartilhamento de saberes e de práticas sociais, vistos em sua pluralidade, e que indaga acerca dos sentidos e de suas implicações para a efetivação de mudanças do cuidado em saúde mental (GERGEN, 1985). É pensar o cotidiano como produtor de conhecimento, nem mais nem menos importante que o conhecimento produzido pela ciência (GRANDESSO, 2000). É, ainda, comprometer-se com o sujeito - profissional, estudante, usuário de serviço ou comunidade.

Partindo-se do pressuposto de que todos possuem um saber, cabe ao "educador" adotar uma "postura do não saber" e produzir diálogos ricos de sentidos em direção à produção de vida e vida com qualidade. Ressaltamos que assumir uma postura de não saber, não significa desqualificar sua formação, mas reconhecer seu saber como um saber local e de caráter provisório, que é desafiado pelo saber do outro num processo de interação (GRANDESSO, 2000).

Para Glasersfeld (1996, p. 80), “o conhecimento é construção"! Podemos falar do conhecimento relativo às nossas experiências, mas nunca com relação a algo que se supõe que exista além do nosso contexto experiencial. 
Toda construção social tem uma história e responde a uma demanda social; portanto práticas inovadoras de ensino/aprendizagem em saúde mental exigem um tipo de olhar que se volta para os cenários que compõem a rede de serviços substitutivos ao hospital psiquiátrico. E, principalmente, para além desses serviços, todos os cenários de ocupação da vida em sociedade, com o propósito de compartilhar as descobertas, os desafios, as possibilidades, os projetos, as dificuldades e as facilidades dessa caminhada.

Debruçar o olhar sobre esse processo de mudança significa ver como se dão as relações entre os diversos atores sociais do ensino/aprendizagem, como também identificar as construções da fala que indicam permanências da cultura manicomial e aquelas que significam rupturas desse modo de pensar e agir. Diante disso, ou a partir disso, incitar a reflexão contínua sobre os contextos vividos, a fim de ter esse ato como um meio de transformar a prática, numa busca por desconstruir as permanências e realizar mudanças no ensino/aprendizagem em saúde mental.

Nesse sentido, um ato importante decide acerca do ponto de partida. Para nós, esse início começou na ocupação do nosso lugar enquanto educadores e educandos na construção do novo em saúde mental. O lugar da educação, embora fundamental para a produção do desenvolvimento e da autonomia de todo cidadão, para servir de fator de proteção à saúde mental, porém não se trata, aqui, de ter sido o caminho melhor ou o mais certo. Aliás, no construcionismo social se desconstroem ideias como essas, e a relatividade dos eventos e das explicações passa a 
ocupar o cenário da produção do conhecimento. Em relação a esse pressuposto, Grandesso (2000, p. 89) ressalta que

o construcionismo social não propõe qualquer critério de verdade por meio do método [...]. A ênfase do construcionismo é colocada sobre a construção do significado pelas pessoas em interação.

Assemelha-se a um convite para uma dança, uma festa ou forma de vida, em que as práticas sociais e possibilidades são consideradas em relação às alternativas desses cenários.

Nesse sentido, a escolha que fizemos é produto do contexto de nossas relações, e, também, da resposta a um convite à responsabilidade. Responsabilidade que queremos compartilhar com o leitor, tendo o desejo de contribuir com o seu cotidiano profissional, e, ainda, de convidá-lo a pensar que o ensino-aprendizagem em saúde mental envolve posicionamentos e diálogos de diferentes atores sociais ligados à construção do novo. No dizer de Evaristo (2000), trata-se de adotar uma postura de não delegar aos outros ações que estão dentro de nós, no cotidiano da produção de saúde mental na comunidade. Nessa trajetória, ressaltamos a complexidade e a importância que teve para nós o intercâmbio entre pessoas de diferentes formações. Assim, concordamos com Spink (2010), para quem as pesquisas ficam mais ricas quando trabalhamos em grupo e, sobretudo, numa perspectiva transdisciplinar e atribuímos esse pressuposto também ao processo ensino/aprendizagem. 
Quanto à produção desse trabalho, a princípio se dirigia aos trabalhadores que compõem as equipes da Estratégia de Saúde da Família (ESF) e aos professores de cinco universidades públicas, em cinco municípios, inclusive a capital do estado da Bahia. Havia uma inquietação por conhecer como ocorria o ensino/ aprendizagem em saúde mental com ênfase na ESF, nos cursos de graduação em Enfermagem e Medicina das universidades, por serem esses de formação para composição de equipes mínimas da referida estratégia. Outra inquietação refere-se aos saberes e às práticas sobre saúde mental que estavam em construção no cotidiano do trabalho das equipes da ESF. Associado a isto havia, ainda, o interesse em dialogar com tais equipes, com o intuito de produzir conhecimento acerca das necessidades e estratégias de aprendizagem na área de saúde mental.

Essas inquietações motivaram a realização de um projeto de pesquisa, financiado pela Fundação de Amparo à Pesquisa do Estado da Bahia (Fapesb), no edital temático de Pesquisas Prioritárias para o Sistema Único de Saúde (PPSUS), no ano de 2006, e desenvolvido no período de março de 2007 a janeiro de 2010.

No projeto de título semelhante a esta obra existiam territórios da ESF para serem explorados nos municípios do estado da Bahia, contendo universidades públicas com cursos de graduação em Enfermagem e Medicina. Uma equipe de saúde da família, por município, foi escolhida para produção de diálogos, tendo como critério o maior número de alcoolistas registrados no Sistema de Informação da Atenção Básica (Siab) do município, uma vez que 
não existiam dados sobre morbidade psiquiátrica no referido sistema.

Participaram da pesquisa médicos, enfermeiros, agentes comunitários de saúde, técnicos de enfermagem e outros membros de equipes da ESF que atuavam nos municípios de Ilhéus, Itabuna, Jequié, Vitória da Conquista, Feira de Santana e Salvador. Em dois desses municípios, o critério de escolha - maior número de alcoolistas - definiu a participação de profissionais que atuavam na área rural.

As trocas desenvolvidas com esses atores sociais foram extremamente valiosas em cada lugar onde ocorreu a produção de diálogos, seja uma Unidade de Saúde da Família da área rural ou urbana dos municípios, por meio de grupos focais, seja o campus de uma universidade pública do interior ou capital do estado, através de entrevistas semiestruturadas com os docentes. Compartilhar parte dessas construções é, pois, o desafio que colocamos a esta obra.

Assim, o leitor poderá perceber como é desafiador olhar para o cotidiano e conferir a riqueza do conhecimento que é produzido frente às múltiplas realidades vividas, com ênfase na saúde e na doença mental. Constatará o quanto desses saberes e práticas fabricadas pela Estratégia de Saúde da Família têm a ver com o que queremos construir de novo. A leitura desta obra ampliará o olhar para ver como a saúde e a doença mental estão imbricadas em todos os aspectos da vida dos profissionais que atuam nessa Estratégia e as razões por que muitos deles pedem "socorro" quando se trata de saúde mental. O leitor será convidado a refletir sobre os recursos da comunidade 
com potencial de uso para o cuidado em saúde mental no território, e como a ideia do não saber, neste caso, significando nada saber sobre a saúde mental, limita os conhecimentos e as ações de saúde mental dos profissionais. Além disso, verá que o cuidado envolve respeito quanto ao que esses profissionais produzem ou são capazes de produzir de conhecimento no cotidiano. Esse respeito e as ideias apontadas por eles como estratégias de ensino/aprendizagem em saúde mental, somadas a tantas outras construções aqui produzidas, poderão significar um caminho de (re) orientação para o suporte instrumental ofertado às equipes da ESF.

Em relação ao Ensino Superior, o leitor verá indícios de uma mudança, especialmente, na relação do professor com os estudantes, e desses com a pessoa em sofrimento psíquico. Nesse processo de mudança, subsistem práticas de ensino que destoam da tendência atual da política de saúde mental no mundo e outras práticas em que são utilizados ou inventados cenários substitutivos ao hospital psiquiátrico, inclusive, a partir do envolvimento de estudantes em projetos de pesquisa e de extensão universitária. As facilidades e dificuldades dessa trajetória dentro e fora da instituição de ensino superior também foram discutidas. Nas dificuldades, o leitor conhecerá os desafios expostos ao docente quando se trata de ensinar e aprender sobre novas práticas de atenção em saúde mental, especialmente, sobre a inserção da saúde mental na ESF. Nesse contexto, os projetos de extensão associados às metodologias participativas nas atividades curriculares possibilitam a criação de diálogos que podem motivar 
a aproximação dos estudantes do universo da saúde mental, produzindo desconstrução de preconceitos.

Como toda construção social é, também, produtora de posicionamentos, coube-nos mais um acréscimo a esta obra - narrar e refletir sobre as experiências de ensino/aprendizagem em saúde mental que foram desenvolvidas a partir da pesquisa. Ou seja, do atendimento às demandas geradas por parte de seus participantes, por parte de outros atores sociais e, ainda, por parte de nós mesmos - pesquisadores - os quais mais uma vez exercitávamos o ato de "tomar para si" a responsabilidade de compartilhar conhecimentos, sem "delegar a alguém fora de nós" tal responsabilidade. Espera-se que elas sirvam de estímulo ao leitor para novas construções.

Assim, o leitor tem em mãos uma produção de diversos sentidos em torno da inserção da saúde mental na Estratégia de Saúde da Família, por meio da qual poderá compreender melhor aspectos que envolvem essa temática. O leitor não ficará surpreso caso sinta-se convidado ou estimulado a se implicar ou ampliar suas relações com o cotidiano e a produzir diálogos conosco, movimentando-se para (re) escrever novos sentidos e práticas sociais de inserção da saúde mental na comunidade. Para isso, lembramos a fala de Grandesso (2000, p. 31) quando diz que "as histórias nunca estão acabadas, estando sempre abertas para serem reconstruídas". É exatamente isso que esperamos com a leitura desta obra. Ela será ainda mais valiosa a partir do diálogo com o leitor, com tudo que ele quiser compartilhar ou produzir de novas configurações ao que está escrito. 


\section{Referências}

EVARISTO, P. Gestão da psiquiatria na comunidade. UNOPAR Científica Ciências Biológicas e da Saúde, Londrina, v. 2, n. 1, p. 27-34, out. 2000.

GERGEN, K.J. The social constructionist movement in modern psychology. American Psychologist, Washington, DC, v. 40, no. 3, p. 266-275, Mar. 1985.

GLASERSFELD, E. A construção do conhecimento. In: SCHNITMAN, D. F. Novos paradigmas, cultura e subjetividade. Tradução J. H. Rodrigues. Porto Alegre: Artes Médicas, 1996.

GRANDESSO, M. Sobre a reconstrução do significado: uma análise epistemológica e hermenêutica da prática clínica. São Paulo: Casa do Psicólogo, 2000.

SPINK, M. J. Linguagem e produção de sentidos no cotidiano. Rio de Janeiro: Centro Edelstein de Pesquisas Sociais, 2010. 

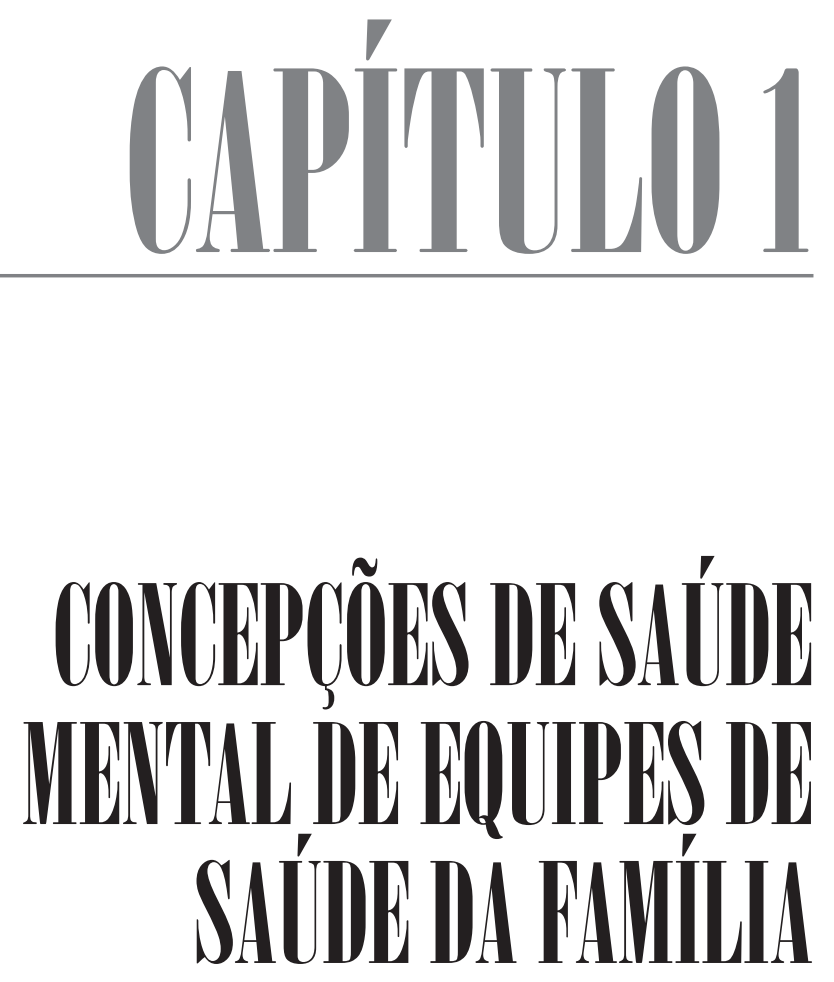

Josentide Engriaciai dos Sintos Rozemere Ciarloso de Sourzia Eriki Intunes Vasconcellos 


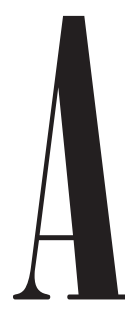

presentamos, de forma abrangente, como equipes da Estratégia de Saúde da Família (ESF) retratam as concepções de saúde mental, norteando as relações de trabalho, as relações interpessoais e as práticas de saúde. Assim, desenvolvemos uma análise das múltiplas concepções de saúde mental, das experiências, dos principais problemas enfrentados e implicações dessas concepções para a promoção da saúde das populações assistidas por essa Estratégia.

Propomo-nos, ainda, a incitar discussões e reflexões a respeito do cuidado, tomando por base as concepções sobre saúde mental. Ressaltamos que os cuidados também passam por essas concepções, ou seja, as ideias e explicações dadas para o sofrimento mental que estão implícitas nas formas de lidar com ele, no cotidiano da atenção primária à saúde. Chamou nossa atenção, em particular, na pesquisa, os modos como as equipes manejavam o sofrimento mental no cotidiano, ou seja, as tomadas de decisões sobre como lidar com usuários que apresentam sofrimento mental não proveniente de um embasamento técnico-científico, mas de saberes e de práticas respaldadas por experiências cotidianas.

Diferentemente da posição dos especialistas em saúde mental, que têm suas condutas definidas por técnicas, as equipes da ESF falam do cuidado em saúde mental de usuários mediante queixas, reclamações e ações intuitivas e/ou coletivas do cotidiano. A compreensão de como essas equipes cuidam dos usuários com sofrimento mental é importante para se entender as estratégias de acolhimento nesses casos que chegam à atenção primária. 
Segundo a Conferência Internacional sobre Cuidados Primários em Saúde (Opas/OMS, 1978), reunida em Alma-Ata, a atenção primária refere-se aos

$$
\begin{aligned}
& \text { cuidados essenciais de saúde, cientificamente } \\
& \text { sustentados e que usa tecnologias e métodos } \\
& \text { socialmente aceitáveis, feitos de forma univer- } \\
& \text { sal para indivíduos e famílias e com um custo } \\
& \text { adequado à comunidade e ao país [...] É parte } \\
& \text { integralizada do sistema de saúde do país [...] O } \\
& \text { primeiro nível de contato dos indivíduos, famí- } \\
& \text { lias e comunidades com o sistema nacional de } \\
& \text { saúde, trazendo os cuidados de saúde tão próxi- } \\
& \text { mos quanto possível de onde as pessoas vivem } \\
& \text { e trabalham, constituindo-se no primeiro ele- } \\
& \text { mento do processo contínuo de atenção à saúde } \\
& \text { (DECLARAÇÃO DE ALMA-ATA, 1978, p. 2). }
\end{aligned}
$$

Em nossa pesquisa, constatamos que dificuldades no plano técnico na abordagem de portadores de transtorno mental repercutem negativamente na autoconfiança das equipes. Este fator impacta no manejo com os usuários e na disposição para serem resolutivos. Nessa direção, assinalaremos o sentido da saúde mental para as ESF e, mais adiante, sobre as iniciativas voltadas para acolher situações de sofrimento mental que estão sendo utilizadas por essas equipes, mediante intervenções baseadas em experiências e na boa vontade dos profissionais.

\section{O cuidado da saúde mental e a estratégia de saúde da família}

Historicamente, o atendimento à saúde da população brasileira sempre se caracterizou por seu aspecto 
curativo e imediatista, hospitalocêntrico, em que as enfermidades são priorizadas e encaminhadas, de forma vertical, campanhista e autoritária.

A implantação do Sistema Único de Saúde (SUS) em nosso país, a partir do conceito de saúde como um direito da população e dever do Estado, presente na Constituição Federal de 1988 e, posteriormente, regulamentado através das Leis Federais 8080/90 (BRASIL, 1990a) e 8142/90 (BRASIL, 1990b), trouxe um novo direcionamento, consolidado através dos princípios doutrinários e organizativos do SUS: universalidade, equidade, integralidade, regionalização, hierarquização, descentralização administrativa e participação popular. Tais princípios são materializados, principalmente, na atenção primária.

Segundo Starfield (2002), a atenção primária é uma abordagem que forma a base e determina o trabalho de todos os outros níveis do sistema de saúde. É a atenção que organiza e racionaliza o uso de todos os recursos, tanto básicos como especializados, direcionados para a promoção, manutenção e melhora da saúde. O Ministério da Saúde propõe como política nacional de atenção primária à saúde, a Estratégia da Saúde da Família (MENDES, 2002).

O Programa de Saúde da Família (PSF), implantado pelo Ministério da Saúde, em 1994, como uma estratégia para a consolidação do SUS, tem-se revelado um instrumento para a modificação dos paradigmas vigentes na atenção à saúde. $\mathrm{O}$ trabalho da ESF é baseado nos princípios do SUS. Esses princípios, segundo o Ministério da Saúde (BRASIL, 1997), buscam, em essência, desenvolver processos de trabalho baseados 
nos conceitos de prevenção, promoção e vigilância da saúde, de forma a atuar precocemente nos momentos iniciais de desenvolvimento das enfermidades, assim como sobre os riscos sanitários e ambientais, por sua vez, geradores de agravos aos indivíduos, garantindo melhores níveis de saúde e qualidade de vida para todos. A Estratégia de Saúde da Família (ESF) inaugurou um modelo inovador de cuidado à saúde, comprometido com a integralidade de assistência que abarca o universo, também, da saúde mental.

Ao investigar as concepções de saúde mental junto às equipes da ESF, nos remetemos a Kleinman (1978), que desenvolveu o conceito de health care system. Esse conceito procura articular, de forma sistêmica, os diferentes elementos ligados à doença e seus cuidados como: experiência dos sintomas, modelos específicos de conduta do doente, decisões concernentes a tratamentos alternativos, práticas terapêuticas e avaliação de resultados terapêuticos. O surgimento de uma doença mental, nessa abordagem, é visto como uma circunstância em que o padrão rotineiro de interação é quebrado e a situação se converte em um problema com o qual os indivíduos têm que lidar.

Nossa pesquisa indicou que as equipes de saúde da família transitam no que Kleinman (1978) denominou três arenas (ou subsistemas) sociais, dentro das quais a doença é experimentada e reagida: popular, profissional e folk. A arena profissional é constituída pela medicina científica, aspecto identificado nas falas dos profissionais de saúde da família quando trazem a necessidade de um especialista: 
- Mas tem a necessidade da psiquiatria do idoso que não é a (psiquiatria) para tratar a grande loucura. Precisa de um especialista (GRUPO 4, 2008, p. 1-13).

- Mas acho que na equipe poderia introduzir um assistente social, psicólogo, terapeuta que seriam figuras importantíssimas (GRUPO 5, 2009, p. 1-11).

O setor folk, segundo Kleinman (1978), é composto pelos especialistas não profissionais de cura, como curadores, rezadores, erveiros, conforme podemos observar:

- Na minha área tem uma igreja que faz cura interior e a gente manda vários pacientes. A cura interior diz que enquanto não cura o que está dentro o externo também não vai curar (GRUPO 4, 2008, p. 1-13).

- Vamos fazer um culto lá na praça (GRUPO 1, 2008, p. 1-21).

O setor popular, segundo Kleinman (1978), compreende não só o contexto familiar da doença - leigo -, mas inclui também redes sociais e atividades comunitárias. A arena popular foi pouco citada pelas equipes investigadas; contudo, para o autor, é justamente nela que a maior parte das questões ligadas a interpretações, tratamentos e cuidados com a doença são resolvidas.

Quando se faz referência ao cuidado, atribui-se ao termo um sentido já consagrado no senso comum, como um conjunto de procedimentos tecnicamente orientados para o bom êxito de um tratamento. 
Contudo, o cuidado também pode ser discutido na perspectiva da hermenêutica filosófica que está relacionada. Segundo Gadamer (2007), há uma nova forma de construir/compreender, tendo por base processos interpretativo-compreensivos, favorecendo o entendimento, a apropriação de uma situação, ou de aspectos dela, que antes não estavam claros e que, por alguma razão, se tornaram problemáticos, ou seja, que merecem ser repensados.

Assim, muitos aspectos relacionados às práticas de saúde podem ser estudados no contexto do trabalho da ESF. Aqui, os conteúdos emergentes dos grupos focais permitiram reunir a construção dos sentidos produzidos por profissionais de saúde da família acerca da saúde mental nas seguintes categorias temáticas: do sujeito e do cuidado em saúde mental.

\section{Sentidos do sujeito acerca da saúde mental}

A pesquisa procurou buscar nos conteúdos emergentes das equipes de saúde da família investigadas o processo, o movimento e o(s) sentido(s) sobre o tema saúde mental. Diversos aspectos das narrativas estavam relacionados ao que Spink (2002) nomeia de práticas discursivas, que são atividades cognitivas ligadas ao conhecimento produzido nas interações das pessoas no cotidiano.

Conforme Davies e Harré (1990), as práticas discursivas são as diferentes maneiras em que pessoas, ativamente, produzem realidades psicológicas e sociais. A referência desses autores possibilitou considerar os grupos focais com equipes da ESF como prática 
discursiva, ou seja, entendê-los como ação (interação) situada e contextualizada, por meio da qual se produzem sentidos e se constroem realidade(s).

Por exemplo, quando um participante diz que saúde mental significa:

- Você estar em equilíbrio com todos esses sentimentos. Se você estiver com todos esses sentimentos aí em equilíbrio e não em um limite, você tem uma saúde mental boa (GRUPO 1, 2008, p. 1-21).

percebemos que os conceitos próprios sobre o sofrimento mental das equipes da ESF são ressignificados a partir do lugar que elas ocupam, dos sistemas simbólicos, de sua cultura. Isso motiva a produção de múltiplos sentidos sobre o tema.

- Saúde mental é bem-estar porque, eu acho assim, quando a gente está bem consigo mesma, a pessoa está bem consigo mesma, ela vai transmitir para a comunidade e para as demais pessoas que estão ao seu derredor (GRUPO 1, 2008, p. 1-21).

Nesse contexto da fala, é preciso estar atento aos processos que fazem a mediação entre as explicações e a forma de lidar com o sofrimento específico para que possamos compreender a dinâmica das relações que compõem este quadro.

No contexto dos cuidados primários, os diagnósticos mais comuns são a depressão, a ansiedade e as perturbações pelo abuso de substâncias. Relatam alguns componentes das equipes da ESF: 
- Além da hipertensão, diabetes, o alcoolismo, drogas, o crack é o maior problema aqui, a gente não sabe o que fazer (GRUPO 7 , 2009, p. 1-10).

- Um dos problemas que a gente vê normalmente no atendimento é a depressão. Mas depressão em geral, ansiedade e alguns casos de esquizofrenia, alguns casos psicóticos. Tem pacientes que fazem uso de medicação controlada, mas mais freqüente é depressão, transtornos do sono. É gente usando remédio pra dormir (GRUPO 2, 2008, p. 1-20).

- Tem um problema que é a festa aqui no A., tráfico de drogas (GRUPO 6, 2008, p. 1-10).

- Bebe de segunda à segunda e acaba perdendo ali o sentido da vida, e a família não tem o que fazer (GRUPO 3, 2008, p. 1-15).

- Para você ter uma ideia, tem uma criança aqui que a arma é mais pesada do que ela. Ela chega a ficar torta. Uma criança com 10 anos arregimentada pelo tráfico e ficam fazendo o papel de vigia. É impressionante. E isso não tem a ver com saúde mental? O que fazer? (GRUPO 6, 2008, p. 1-10)

Esses problemas estão presentes isoladamente ou em conjunto com uma ou mais afecções físicas, bem como se relacionam com variáveis sociodemográficas, como a comunidade de baixa renda, precária inserção no mercado de trabalho e falta de oportunidades, principalmente para a criança e o adolescente. A interpretação de que a saúde mental está relacionada à estrutura familiar foi constatada em relatos como: 
- Eu moro numa comunidade que saúde mental, onde a gente trabalha, a gente vê, é um desequilíbrio total, né?! A gente olha assim, não tem uma família estruturada, então pai bebe, filho bebe, mãe bebe (GRUPO 1 , 2008, p. 1-21).

- Saúde mental tem a ver com violência contra a mulher, violência contra a criança, violência familiar. Toda a questão. Condições mesmo do dia a dia que são fonte de estresse que, de alguma maneira, afeta a saúde mental sem se configurar uma doença mental, psiquiátrica (GRUPO 4, 2008, p. 1-13).

Os fragmentos de discursos apresentados acima, por exemplo, indicam que quando a violência é dirigida contra membros da família, a mãe, em especial, caracteriza situação particularmente problemática. Atitudes de desobediência com relação à mãe podem ser expressão de graves distúrbios, e essa avaliação está relacionada com a importância da família como o cerne moral da vida social (SOUZA; CARVALHO, 2003). Vejamos:

- Se a gente for buscar lá atrás, porque acho que a construção da família influencia nisso tudo. Você tem adolescente que tem filhos cedo e não tem estrutura emocional nem financeira para manter. Esses filhos são maltratados e sofrem violências de todas as maneiras desde criança e, quando crescer, vai ser um adulto violento. Então, eu acho que a preocupação com a família, com a situação da família, com a gravidez precoce, tudo isso é uma prevenção à violência que vem no 
futuro, em decorrência dessas crianças que são maltratadas (GRUPO 2, 2008, p. 1-20).

- Se a gente for pensar por esse ângulo, a questão de saúde mental independe de ter ou não as questões financeiras. Por quê? Porque está ali no meio da estrutura familiar. Se uma mãe grita com o filho, o filho vai aprender o quê? A gritar também. Ele vai parar para escutar alguém? Não vai. A vida dele vai ser gritar [...]. Então, eu acho que o problema está na família, independente de ter ou não condições financeiras (GRUPO 2, 2008, p. 1-20).

Os problemas de saúde mental dizem respeito, principalmente, à família associada à vivência de problemas no cotidiano, em especial, de relacionamento familiar ou conjugal.

Sobre a relação com o dinheiro, os trechos a seguir exemplificam outra concepção que explica a saúde mental:

- Eu acho que tem a ver com o lado social e também tem a ver com o momento. O dinheiro está ligado a tudo. O dinheiro está enlouquecendo todo mundo, e é verdade: às vezes quem tem muito fica doido (GRUPO 5, 2009, p. 1-11).

Bourdieu (2007) amplia a noção de capital e faz, assim, com que possamos compreender as trocas simbólicas ocorridas em outros campos, guardando algum tipo de analogia com a economia, na medida em que é definido, de forma genérica, como um recurso (estrutura estruturante) que rende lucros para quem o possui. 
O sentido da saúde mental nos relatos remete a um mundo já dado e, também, socialmente construído nos intercâmbios entre as pessoas, envolvendo um passado e cotidiano, dentre outros aspectos, de abandono, de violência e de dificuldades para criar os filhos sem os meios necessários:

- Aquele indivíduo que pensa: Como é que vou conseguir comprar amanhã o leite das minhas crianças? Como é que vou dar uma vida digna para meus filhos? Como vou fazer com que esses meninos frequentem a escola se estou desempregado? (GRUPO 5, 2009, p. 1-11)

- Eu penso que para se ter uma saúde mental, tem que ter um emprego, tem que ter uma boa moradia, tem que pelo menos tentar ter uma vida equilibrada (GRUPO 1, 2008, p. 1-21).

- Dificuldades financeiras e desemprego trazem a violência, com as desigualdades sociais, e afetam diretamente na saúde mental dos indivíduos (GRUPO 5, 2009, p. 1-11).

- Aqui na comunidade nós temos muitos alcoolistas, drogas, desemprego, falta de educação, a pessoa que não conseguiu estudar para conseguir um bom emprego, aí, sobra para ela o desequilíbrio mental (GRUPO 7, 2009, p. 1-10).

- É muito pior para trabalhar com a comunidade. Já pensou uma mãe sem dinheiro para manter os filhos? (GRUPO 7, 2009, p. 1-10)

Nesses trechos, o que podemos identificar é que os sentidos de saúde mental empregados estão 
relacionados, segundo Rabelo, Alves e Souza (1999), à forma: de cultura das equipes de saúde da família, de envolvimento e de afetações pelas condições de vida, de acesso aos bens e serviços da população assistida e de organização dessas experiências enquanto situações que sentem "na pele".

- Como é que isto afeta a comunidade que a gente vive? Quantas e quantas vezes a gente fica, como é que posso dizer, impossibilitado da gente desenvolver nossas atividades (GRUPO 5, 2009, p. 1-11).

O material registra, também, que os sentidos produzidos estão inseridos em uma dinâmica de experiência de equipes da ESF na qual o político, o social e o cultural não são sentidos abstratos, mas dimensões vividas sem desprezar o conjunto das condições que interfere na vida.

Aqui, a queixa aparece relacionada aos aspectos individuais, tais como: personalidade (comportamentos, "gênio difícil"); diferenças individuais, que fazem com que algumas pessoas tolerem mais decepções ou frustrações do que outras; um "ponto fraco" que, quando atingido, leva ao adoecimento.

Esta explicação aparece em momentos de grande participação e remete à responsabilização pessoal pela própria mudança. Fenômeno individual relacionado ao comportamento (atitude): a doença mental é decorrente de características pessoais. Assim, ela tem a ver com os significados que as coisas têm para si mesmo: 
- Até porque eu vejo assim, que as pessoas estão normais agora e pergunto: Meu Deus, por que eu, quando me vejo numa situação que estou prestes a pirar, saio e faço outra coisa. Tem gente que não tem esse freio e deixa aquilo tomar conta, e aí não tem jeito (GRUPO 7, 2009, p. 1-10).

- As pessoas adoecem por coisas que acontecem na vida (GRUPO 7, 2009, p. 1-10).

- Saúde mental é uma atitude que a pessoa tem; é uma mudança de comportamento (GRUPO 4, 2008, p. 1-13).

Segundo Goffman (1983), o significado da identidade se constitui no processo de interação; ele surge e se modifica na medida em que pessoas estabelecem e negociam as suas incumbências imediatas e cotidianas.

A concepção de self presente é de que este é um objeto social que se estrutura com base na sociabilidade, ou seja, a partir das atitudes dos indivíduos uns com os outros em uma situação social. Uma interpretação relaciona essa concepção ao Interacionismo Simbólico, que repousa sobre três pressupostos: 1) Que os seres humanos agem sobre os objetos com base nos significados que os objetos têm para eles; 2) O significado surge no processo de interação social 3) Os significados são modificados através de um processo interpretativo que envolve indivíduos capazes de refletir sobre si mesmos, interagindo simbolicamente uns com os outros (BLUMER, 1966). Disso decorre o sentido de que a saúde mental depende do sujeito, que é, também, uma construção social. 
Como é questionado por uma profissional de saúde da família:

- Mas morrem filhos todos os dias, 99\% das mães amam seus filhos e porque umas adoecem e outras não? Algumas pessoas têm estrutura para suportar aquela perda, mas outras não (GRUPO 7, 2009, p. 1-10).

Cassel (1974) e Kaplan et al. (1977) afirmam que determinados acontecimentos na vida dos indivíduos atuam como estressores não específicos, aumentando, dessa forma, o risco de desenvolvimento de doenças, dentre as quais os distúrbios mentais.

O sentido da saúde mental é produzido a partir de diferentes compreensões e olhares das equipes da Estratégia de Saúde da Família (ESF) e ultrapassa a perspectiva centrada na doença mental, permeando todo o desenvolvimento do ser humano a partir de sua estrutura e dinâmica familiar. Quando, em suas narrativas sobre a saúde mental, as equipes retratam a desigualdade social, a família e a atitude individual, elas falam do que é inerente à existência, às interações sociais e nos lembram de que estamos em um mundo entregues a certas possibilidades e disposições.

A ideia de que problemas sociais ou econômicos guardam relação com o surgimento do adoecimento mental está associada à visão de que suas possibilidades de mudança, de promoção, de recuperação e proteção dessa enfermidade dependem, também, de uma mudança nesses aspectos sociais e econômicos que causam seus problemas, mas que não implica determinação. Nessa perspectiva, ela está associada 
à experiência vivida, que encontra seu sentido no cotidiano e que abre, de forma incerta e ambígua, certa direção para o futuro, ainda que seja promovida junto aos especialistas.

\section{O cuidado em saúde mental}

Os trabalhos que envolvem a temática da produção de cuidado das equipes de saúde da família parecem se inscrever, predominantemente, em vertentes biomédicas relacionadas a eventos, como hipertensão e diabetes, excluindo outras visões, como o sofrimento mental na atenção primária.

Observa-se que a pouca importância e a própria exclusão dessa discussão em torno da produção de cuidado em saúde da família voltada à saúde mental na atenção primária não correspondem à grande dificuldade encontrada na prática, que limita a ação dos profissionais no cotidiano das intervenções:

- Eu, na realidade, tenho medo, porque eu não sei como lidar com essas pessoas (GRUPO 1, 2008, p. 1-21).

- Eu tenho medo, eu não sei como lidar. Tenho medo, muito medo. Eu converso com ele, pergunto as coisas para ele. Ele diz que está bem, pergunto se está tomando o remédio, ele diz que está. Mas assim, vou, assim, sabe, insegura (GRUPO 1, 2008, p. 1-21).

- Minha inquietação é como vou solucionar aquele problema de saúde mental, como vou me inserir naquela família para resolver o problema. Como pode ser as minhas 
colocações? Como intervir para resolver o problema? (GRUPO 5, 2009, p. 1-11)

- Como lidar com problemas mentais na atenção básica. Atribuições, como lidar com paciente, o que fazer (GRUPO 5, 2009, p. 1-11).

- Porque a equipe também é assim, é uma equipe só para dar conta de uma tarefa tão grande como essa (GRUPO 3, 2008, p. 1-15).

Alia-se a esse olhar sobre o cuidado em saúde mental a preponderância dessa vertente no discurso dos profissionais que, muitas vezes, restringem o acesso e fecham as possibilidades de perceberem o sujeito em sofrimento psíquico, nas suas dimensões sociais, culturais e psicológicas. Nesse sentido, lembramos que não podemos perder de vista que, na qualidade de portador de um problema a ser resolvido, qualquer indivíduo é, de fato, objeto de técnicos da saúde e requer cuidado.

A ideia de cuidado vem, justamente, tentar reconstruir uma atenção integral à saúde de indivíduos e comunidades, buscando recompor competências, relações e implicações ora fragmentadas, empobrecidas e desconexas. O cuidado também tem a ver com atitude e com a oferta de espaço para reconstrução de intersubjetividades, tal como podemos observar no seguinte relato de um profissional da ESF sobre uma usuária:

- Ela está muito desanimada, não quer almoçar, e eu fico levantando o ânimo dela (GRUPO 4, 2008,p. 1-13). 
É um exercício aberto à aprendizagem significativa, apoiada na tecnologia da leveza, mas sem deixar de ser uma intervenção em saúde:

- A gente, muitas vezes, faz um trabalho corpo a corpo. Digo a ele: - Você tem que fazer alguma atividade. Saia, caminhe, faça qualquer coisa. Ele diz: - O que eu vou fazer? Eu respondo: - Você vai achar. Ele está se acabando. Fico, assim, animando (GRUPO 4, 2008, p. 1-13).

Mais que uma ação teleológica, a intervenção se apoia não tanto no estado de saúde visado de antemão, nem somente nas formas como se busca alcançá-lo, mas na experiência que une o conteúdo da primeira ao movimento da segunda. $O$ cuidado é essa atividade realizadora na qual caminho e chegada se engendram mutuamente, que abre espaço à reflexão e negociação sobre meios e fins da assistência à saúde mental sem determinar, a priori, aonde e como chegar com a assistência.

Os questionamentos das equipes de saúde da família são pautados nos sistemas de apoio ao atendimento integral do usuário que vai a busca da ESF. Exemplo:

- Primeiro lugar, a gente não sabe o que fazer com estes pacientes. Teve um paciente psiquiátrico que a gente tentou levar para o hospital e o hospital não aceitou. Tentamos e o hospital não atendeu. É isto que me incomoda bastante. É um paciente que tem outros problemas clínicos e o hospital geral não aceita porque é paciente psiquiátrico. Ele tem outras doenças e eles não vêem de forma integral (GRUPO 4, 2008, p. 1-13). 
- Foi encaminhada para o Caps e o Caps liberou, porque esse tratamento ela poderia fazer no PSF (GRUPO 4, 2008, p. 1-13).

Outra situação vinculada às concepções de saúde mental são as queixas inespecíficas de usuários da ESF que chegam aos profissionais:

- Por serem casos que, na verdade, não é a grande loucura do paciente psiquiátrico, a gente tem dificuldade de encaminhar. Eu como médico não me sinto preparado para acompanhar e tratar, é um paciente que não consigo identificar benefício medicamentoso, que não vou encaminhar para o Caps, pois ele não vai receber atendimento pelo fato do serviço estar voltado para pacientes mais graves (GRUPO 4, 2008, p. 1-13).

Segundo Fonseca (2007), as clientelas consideradas menos graves ainda não são objetos de investimentos e atenção até mesmo das políticas de saúde em geral. O que podemos perceber na fala é que parte significativa daqueles que pedem ajuda nos serviços de saúde por queixas somáticas inespecíficas apresenta uma dificuldade no manejo das manifestações de sofrimento, que não é a loucura clássica, o que dificulta o encaminhamento dos profissionais.

Uma das características presentes nos discursos analisados foi a necessidade de cuidado para a equipe da ESF, pois as dores e sofrimentos que atingem os usuários podem atormentar os profissionais:

- É muito sobrecarga e, aí, eu digo: - Não aperte minha cabeça. Não aperte minha 
mente não! Você fica sentindo impotência e qualquer ser humano, qualquer pessoa pode surtar (GRUPO 6, 2008, p. 1-10).

- Pelo dia a dia, pelo desempenho, a mente do ser humano é capaz de algo maravilhoso, mas ao mesmo tempo é frágil (GRUPO 6, 2008, p. 1-10).

- Para a gente começar a fazer um trabalho externo, é necessário um trabalho interno com o psicológico e equilíbrio da gente, pois a gente anda muito estressado, por conta de toda essa problemática que tem aqui. Eu preciso ser trabalhada primeiro, para trabalhar lá fora. $\mathrm{Eu}$, sinceramente, me sinto insegura de fazer atividades externas, pois eu tenho os mesmos traumas que eles. Eu não tenho equilíbrio porque sofro dos mesmos problemas que a comunidade. Eu não vou para lá mostrar uma coisa que eu não sou (GRUPO 5, 2009, p. 1-11).

- Um trabalho com todos os profissionais. Como é que a gente vai passar uma boa imagem da unidade, quando a unidade está capenga. Como é? A gente não pode passar uma coisa boa se não é? (GRUPO 5, 2009, p. 1-11)

- Às vezes, o agente comunitário fica mais doido do que a comunidade. Cada agente tem sua comunidade para tomar conta e cada uma tem uma coisa diferente e tem que ouvir um pouco de cada um, com diferentes necessidades de atenção. Tem que fazer uma preparação psicológica aqui, um balanço interno para poder lidar com isso (GRUPO 5, 2009, p. 1-11). 
As questões pessoais e profissionais em torno da saúde mental se misturam na prática diária e os membros das ESF se identificam com os problemas da comunidade, gerando também demanda para um cuidado voltado para a equipe.

Os agentes comunitários de saúde são os profissionais mais expostos aos dramas familiares dos usuários, pois residem na mesma área dos pacientes e uma das suas funções é a visita domiciliar. São indivíduos com intensa sobrecarga emocional, muitos deles entram em sofrimento psíquico, sem conseguir separar o pessoal do profissional:

- Eu tive no Juliano Moreira e o psiquiatra disse que qualquer um de nós pode, de repente, ter um surto, e isso me deixou um pouco preocupada. Meu Deus, meu Deus! Qualquer um de nós pode ficar assim, devido a muito stress e muitos problemas (GRUPO 6, 2008, p. 1-10).

Assim, cada um dos trechos das narrativas apresentadas revela a riqueza das múltiplas experiências das equipes de saúde da família, destacadas pela análise teórica que permite lançar um novo olhar sobre o assunto. 


\section{Referências}

BRASIL. Lei n. ${ }^{\circ}$ 8.080, 19 de setembro de 1990. Dispõe sobre as condições para a promoção, proteção e recuperação da saúde, a organização e o funcionamento dos serviços correspondentes e dá outras providências. Diário Oficial [da República Federativa do Brasil], Brasília, DF, n. 182, 20 set. 1990a. Seção 1. p. 18.055-18.059.

BRASIL. Lei n. ${ }^{\circ}$ 8.142, de 28 de dezembro de 1990. Dispõe sobre a participação da comunidade na gestão do Sistema Único de Saúde (SUS) e sobre as transferências intergovernamentais de recursos financeiros na área da saúde e dá outras providências. Diário Oficial [da República Federativa do Brasil], Brasília, DF, 31 dez. 1990b. Disponível em: <http://www.planalto.gov.br/ccivil_o3/leis/18142.htm>. Acesso em: $1^{0}$ out. 2013.

BOURDIEU, P. O poder simbólico. Tradução Fernando Tomaz, 10. ed. Rio de Janeiro: Bertrand Brasil, 2007.

BLUMER, H. Symbolic interactionism: perspective and method. New Jersey: Prentice Hall, 1966.

CASSEL, J. Psychosocial process and stress: theoretical formulation. International Journal of Health Services, [s.l.], v. 4, no. 3, p. 471-82, 1974.

DAVIES, B.; HARRÉ, R. Positioning: the discursive production of selves. Journal for the theory of Social Behavior, Malden, v. 20, no. 1, p. 43-63, Mar. 1990.

DECLARAÇÃO de Alma-Ata. URSS : Conferência internacional sobre cuidados primários de saúde Alma-Ata, 1978. 
FONSECA, M. L. G. Sofrimento difuso, transtornos mentais comuns e problemas de nervos: uma revisão bibliográfica a respeito das expressões de mal estar nas classes populares.2007. Dissertação (Mestrado em Saúde Pública)- Escola Nacional de Saúde Pública, Fundação Oswaldo Cruz, Rio de Janeiro, 2007.

GADAMER, Hans-Georg. Verdade e método. Tradução Flávio Paulo Meurer, 8. ed. Rio de Janeiro: Vozes, 2007.

GOFFMAN, E. A representação do eu na vida cotidiana. Tradução Maria Célia dos Santos Raposo, 2. ed. Petrópolis: Vozes, 1983.

GRUPO1. Projeto Construção Social da Aprendizagem acerca da Saúde Mental e Saúde da Família: grupo de discussão [maio 2008]. Moderadores: Rozemere Cardoso de Souza e Erika Antunes Vasconcellos. Jequié: Uesc: Fapesb, 2009, gravador digital. p. 1-21. Grupo de discussão produtor sobre a inserção da saúde mental na Estratégia de Saúde da Família.

GRUPO 2. Projeto Construção Social da Aprendizagem acerca da Saúde Mental e Saúde da Família: grupo de discussão [ago. 20o8]. Moderadores: Rozemere Cardoso de Souza e Erika Antunes Vasconcellos. Ilhéus: Uesc: Fapesb, 2009, gravador digital. p. 1-20.Grupo de discussão produtor sobre a inserção da saúde mental na Estratégia de Saúde da Família.

GRUPO 3. Projeto Construção Social da Aprendizagem acerca da Saúde Mental e Saúde da Família: grupo de discussão [abr. 2008]. Moderadores: Rozemere Cardoso de Souza e Erika Antunes Vasconcellos. Vitória da Conquista: Uesc: Fapesb, 2009, gravador digital. p. 1-15. Grupo de discussão produtor sobre a inserção da saúde mental na Estratégia de Saúde da Família. 
GRUPO 4. Projeto Construção Social da Aprendizagem acerca da Saúde Mental e Saúde da Família: grupo de discussão [maio 2008]. Moderadores: Josenaide Engracia dos Santos. Feira de Santana: Uesc: Fapesb, 2009, gravador digital. p. 1-13. Grupo de discussão produtor sobre a inserção da saúde mental na Estratégia de Saúde da Família.

GRUPO 5. Projeto Construção Social da Aprendizagem acerca da Saúde Mental e Saúde da Família: grupo de discussão [maio 2009]. Moderadores: Josenaide Engracia dos Santos. Salvador: Uesc: Fapesb, 2009, gravador digital. Grupo de discussão produtor sobre a inserção da saúde mental na Estratégia de Saúde da Família. p. 1-11.

GRUPO 6. Projeto Construção Social da Aprendizagem acerca da Saúde Mental e Saúde da Família: grupo de discussão [nov. 2008]. Moderadores: Josenaide Engracia dos Santos. Salvador: Uesc: Fapesb, 2009, gravador digital. p. 1-10. Grupo de discussão produtor sobre a inserção da saúde mental na Estratégia de Saúde da Família.

GRUPO 7. Projeto Construção Social da Aprendizagem acerca da Saúde Mental e Saúde da Família: grupo de discussão [abr. 2009]. Moderadores: Josenaide Engracia dos Santos. Ilhéus: Uesc: Fapesb, 2009, gravador digital. p. 1-10. Grupo de discussão produtor sobre a inserção da saúde mental na Estratégia de Saúde da Família.

KAPLAN, B. H.; CASSEL, J. C.; GORE, S. Social support and health. Medical Care, Washington, DC, v. 15, no. 5, p. 47-58, May 1977.

KLEINMAN, A. Concepts and Model for the Comparison of Medical Systems. Social Science and Medicine, [Atlanta], v. 12, p. 85-93, 1978. Bimestral. 
MENDES, E.V. A atenção primária à saúde no SUS. Fortaleza: Escola de Saúde Pública do Ceará, 2002.

MINISTÉRIO DA SAÚDE. Saúde da família: uma estratégia para reorientação do modelo assistencial. Brasília,DF: Ministério da Saúde, 1997. Disponível em: < http://bvsms.saude.gov.br/bvs/publicacoes/cdo9_16. pdf $>$. Acesso em: $1^{0}$ out. 2013.

RABELO, M. C. M.; ALVES, C. B.; SOUZA, I. M. A. Signos, significados e práticas relativos à doença mental. In: Rio de Janeiro: Fiocruz, 1999. (org.) Experiência de doença e narrativa.

SOUZA, R. A.; CARVALHO, A. M. Programa de Saúde da Família e Qualidade de Vida: um Olhar da Psicologia. Estudos de Psicologia, v. 8, n. 3, p. 515-523, 2003.

SPINK, M. J. P. (org.). Práticas discursivas e produção de sentidos no cotidiano: aproximações teóricas e metodológicas. 3. ed. São Paulo: Cortez, 2002.

STARFIELD, B. Atenção primária: equilíbrio entre necessidades de saúde, serviços e tecnologia. Tradução Fidelity Translations. Brasília, DF: Unesco: Ministério da Saúde, 2002. 

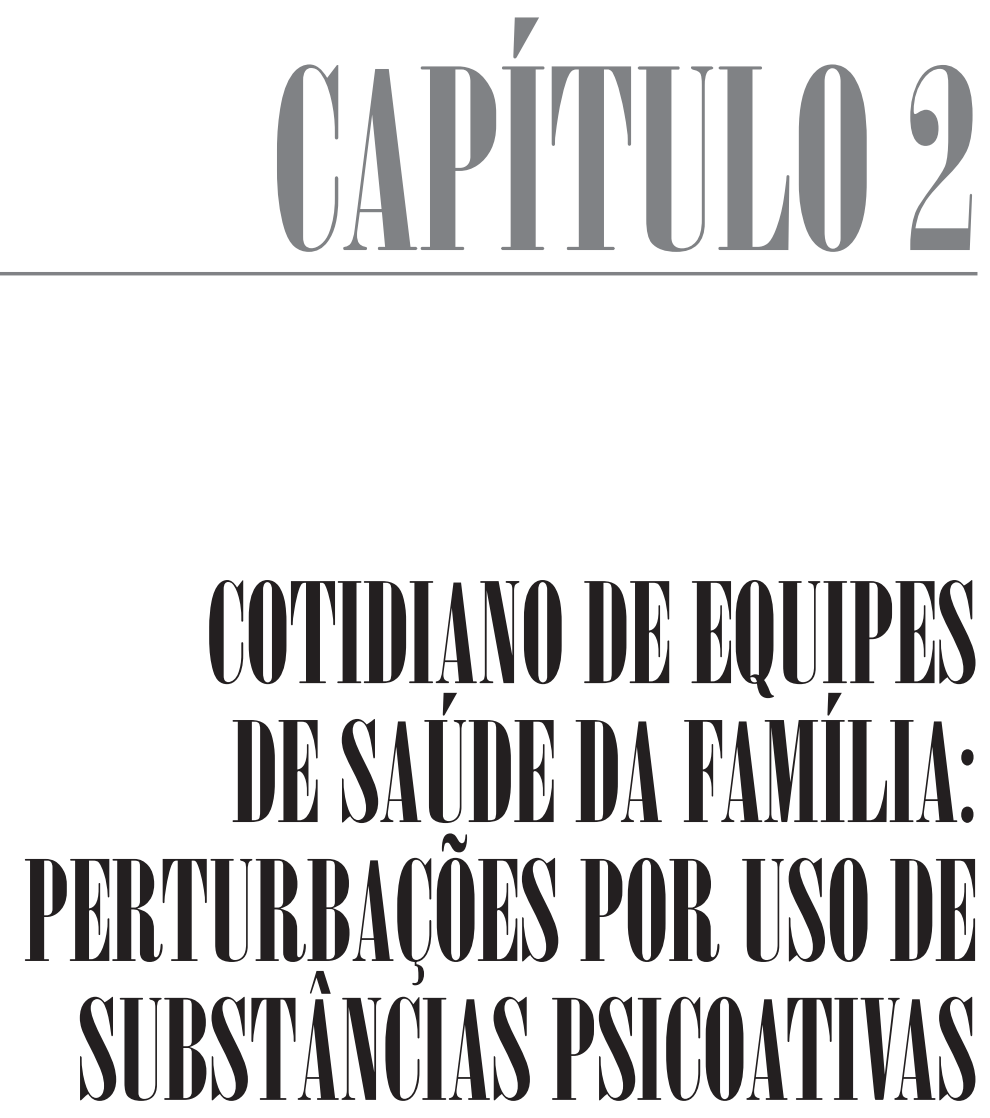

Josenaide Engraciaia dos Sientos Rozemere Carrdoso de Sonza 


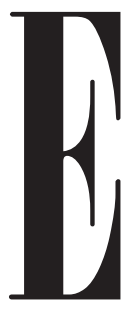

ste capítulo abordará o uso de substâncias psicoativas referidas pela equipe de saúde da família. A equipe opera com a abordagem familiar em integração com a comunidade, com intervenção oportuna e precoce, dando ênfase à promoção e à prevenção em saúde.

Nesse sentido, serão descritas variáveis sociodemográficas - renda, escolaridade, inserção no mercado de trabalho, rede de apoio social - e aspectos relacionados ao gênero feminino, que explicam, associam ou se relacionam com os transtornos por uso e abuso de álcool e outras drogas, bem como situações de violência urbana.

O tema das drogas entre a equipe de saúde da família torna-se uma questão de grande relevância, por conter imbricado, enquanto fato social, um fenômeno que afeta a moralidade da sociedade e se constitui como um problema de políticas públicas.

Segundo as equipes de saúde da família, a violência e o temor estão presentes no cotidiano das pessoas que vivenciam o desconforto de presenciarem, com alguma regularidade, o uso de drogas: “- Tem um problema que afeta aqui no A., o tráfico de drogas” (GRUPO 6, 2008, p.1-10). Os grupos de crianças e jovens enfrentam dificuldades referentes à escassez de políticas públicas retratada na falta de lazer, cursos, oficinas, escolas, o que gera ociosidade, tornando-os vulneráveis ao investimento do tráfico de drogas: "- Só os jovens que não têm trabalho e que não têm com que se ocupar partem para o mundo das drogas" (GRUPO 4, 2008, p. 1-13). 
O fascínio exercido pelas drogas e pelo "crime", tido como promessa de ganho fácil, num contexto marcado pela pobreza e em grande medida pelo desemprego, é uma ameaça real, como percebemos no seguinte relato: "- São muitos jovens envolvidos com drogas. Em minha rua só tem três pontos de drogas" (GRUPO 2,2008, p. 1-13). Isto abre caminho para outras influências, como a de traficantes, de acordo com as falas:

- Para você ter uma ideia, tem uma criança aqui que a arma é mais pesada do que ela. Ela chega ficar torta. Uma criança com 10 anos arregimentada pelo tráfico e ficam [sic] fazendo o papel de vigia. É impressionante (GRUPO 6, 2008, p.1-10).

- É tanta criança perdida, que acho que o único meio é planejamento familiar. Se não a gente vai alimentar o tráfico (GRUPO 6, 2008, p. 1-10).

O panorama dos espaços cotidianos da saúde da família é permeado de violência e drogas, como relata um profissional da equipe da ESF: "- O crack é o maior problema aqui, e a gente não sabe o que fazer" (GRUPO 7, 2009, p. 1-10). Outras pesquisas, como a do Centro Brasileiro de Informações sobre Drogas Psicotrópicas (Cebrid) (2007), já vêm alertando sobre o aumento do "uso na vida" de crack, pela população geral, desde o ano de 2001, bem como para os riscos desse fenômeno.

O não saber o que fazer, narrado por alguns profissionais, está, em parte, relacionado à dificuldade de manejo dos usuários, à escassez de informações sobre 
possibilidades de encaminhamentos e às necessidades de assistência às famílias. Além disso, os usuários de crack apresentam dificuldade de expressar demandas e de acessar ajuda, conforme observamos nos relatos:

- Os jovens não participam (GRUPO 4, 2008, p. 1-13).

- No consultório [...] droga não vem (GRUPO 4,2008, p. 1-13).

- Drogas é um ponto importante na atenção em saúde mental (GRUPO 4, 2008, p. 1-13).

Outro aspecto evidenciado foi a violência: "- Temos um morro aqui no subúrbio que só podemos entrar com a permissão dos chefes. Nem a polícia entra. Foge ao nosso controle" (GRUPO 7, 2009, p.1-10). Sobre isso, Vasconcelos (2001) afirma que o medo da violência tolhe iniciativas de ação mais integradas à comunidade. Para esse autor (2001), a violência provoca um distanciamento do morador em relação ao local de seu viver cotidiano e ele passa a não ser mais outro com quem se busca relações igualitárias.

Cenas de agressão, desde aquelas praticadas pelos "bandidos", como também as brigas entre vizinhos ou casais, são permanentes segundo relatos. Para Vasconcelos (2001), a violência, mesmo com todas as explicações, continua sendo atitude que fere e torna ainda mais superficiais as relações entre os vários envolvidos no enfretamento dos problemas na comunidade. Além disso, quando associada às drogas implica em danos 
permanentes à vida, gerando impacto na morbimortalidade referida pelas equipes. Como exemplo, citamos o relato: "- Violência mata o tempo todo aqui. Tem um vizinho meu que era viciado e hoje está numa cadeira de rodas devido a tiro" (GRUPO 7, 2009, p. 1-10).

Os episódios relatados pelas equipes ilustram que a violência perpassa o cotidiano das camadas mais pobres. Para Velho (2003), os moradores estão sujeitos permanentemente a todos os tipos de arbitrariedade, desde a violência de bandidos, somados à falta de emprego e de moradia, dentre outras dificuldades que constituem a existência das comunidades.

O sentido de que problemas sociais ou econômicos guardam relação com os sintomas apresentados também emergiu na fala de um enfermeiro, que retoma o tema da droga ao se referir ao alcoolismo:

- Eu coloquei as famílias carentes, porque muitos recebem a bolsa família e os pais vão. Estão ali, parados. Compra um quilo de alimentos e o resto do dinheiro pega e vai beber. Passa a semana toda (GRUPO 3, 2008, p. 1-15).

O consumo do álcool e outras drogas agrava alguns problemas sociais, traz sofrimento para indivíduos e famílias:

[...] está envolvido com alto índice de alcoolismo, família inteira que são alcoólatras, a mãe é alcoólatra, o pai é alcoólatra, os filhos grandinhos já estão ficando também porque vê o pai e a mãe beber.

Através do alto índice de alcoolismo vem a prostituição, drogas, então, quer dizer, não 
tem uma faixa etária de idade (GRUPO 1, 2008, p. 1-21).

Uma pesquisa realizada pelo Instituto Nacional de Abuso de Álcool e Drogas, dos EUA, revelou que o uso excessivo de bebida estava presente em 68\% dos homicídios culposos, 62\% dos assaltos, $54 \%$ dos assassinatos e $44 \%$ dos roubos ocorridos (NEUBERG; SMITH; ASHER, 2003). Em relação à violência doméstica, a mesma pesquisa evidenciou que 2/3 dos casos de espancamento de crianças ocorrem quando os pais agressores estão embriagados, o que também vale para as agressões entre marido e mulher. Observamos tal aspecto também em nosso levantamento:

Uma paciente da microárea que foi esfaqueada. Nós fizemos a visita para fazer curativo. E quando chegamos lá, a gente ficou sabendo que quem esfaqueou ela foi o marido (GRUPO 6, 2008, p. 1-10).

Especialmente no que concerne ao álcool, nele está presente um processo de estigmatização:

Aí já é tratado com preconceito, acha que o alcoolismo não é uma doença. Aí começa a reclamar, chamar de vagabundo, aquela coisa, entendeu? Nisso a pessoa se sente inferior (GRUPO 3, 2008, p. 1-15).

Segundo Neuberg, Smith e Asher (2003), devemos considerar a prática da estigmatização como manifestação comportamental de um processo cognitivo em que o indivíduo é marcado como possuidor de 
uma característica negativa e passa a ser definido em termos deste atributo.

Nesse contexto, a atenção da equipe de saúde da família não consegue atender à demanda, porque a saúde mental continua segregada aos serviços especializados, como os Centros de Atenção Psicossocial (Caps), os quais não têm exercido o papel de "dar suporte e supervisionar a atenção à saúde mental na rede básica, PSF (Programa de Saúde da Família), PACS (Programa de Agentes Comunitários de Saúde)" (BRASIL, 2004, p. 13). Logo, as equipes da ESF sentem o impacto dessa desarticulação: "- Acho que essa questão da referência com o Caps, essa relação, interface entre o PSF e o Caps poderia ser melhorada" (GRUPO 4, 2008, p.1-13).

Paralelo a isso, quando os Caps supervisionam as ações de saúde mental na atenção primária muitas vezes não conseguem disponibilizar recursos factíveis para atuarem na prevenção do adoecimento mental, na promoção da saúde e no uso abusivo de álcool e outras drogas. No entanto, a equipe mantém estratégias de suporte, ainda que as considere frágeis, como podemos observar:

- Eu, como médico, acredito muito em remédio, mas tinha uma frase de uma professora minha, que me marcou muito, que dizia assim: 'É ingênuo o tratamento sem remédio e é cruel tratar sem psicoterapia, sem nenhum tipo de apoio'. E eu acho que isso faz muita falta. Muitas vezes consegue tratar com medicação. Só com medicação e muitas vezes melhoram, mas a gente vê que poderia fazer melhor. 
- Um professor fez uma palestra sobre droga, mas não atingiu toda área (GRUPO 4, 2008, p.1-13).

-Nós chamamos a família para participar da discussão sobre drogas. Ai vem o pai, a mãe, o irmão e o tio que estão passando pelos problemas. Até as esposas vão, mas os jovens não vão (GRUPO 4, 2008, p. 1-13).

Segundo Dimenstein et al. (2009), é importante que sejam estabelecidas estratégias de ação contextualizadas, com articulação entre a saúde mental e a atenção básica.

Corroborando com Flora (2008), os resultados da pesquisa indicam que as equipes não conseguem responder aos complexos desafios da saúde mental e, especificamente, ao uso abusivo de álcool e outras drogas. A pesquisa demonstra, ainda, que a inserção da atenção e da prevenção em álcool e outras drogas na Estratégia de Saúde da Família está vinculada à necessidade de qualificação dos profissionais em relação a como identificar casos precocemente e sobre o manejo da situação. Por isso a necessidade de estabelecer um processo de educação permanente que possa representar aberturas para um trabalho efetivo de prevenção e promoção da saúde e da qualidade de vida.

\section{Referências}

BRASIL. Ministério da Saúde. Secretaria de Atenção à Saúde. Departamento de Ações Programáticas Estratégicas. Saúde mental no SUS: os centros de atenção psicossocial. Brasília, DF: Ministério da Saúde, 2004. 
CENTRO BRASILEIRO DE INFORMAÇÕES SOBRE DROGAS PSICOTRÓPICAS (Cebrid). II Levantamento domiciliar sobre o uso de drogas psicotrópicas no Brasil: estudo envolvendo as 108 maiores cidades do país. São Paulo: CEBRID: Unifesp, 2007.

DIMENSTEIN, M. et al. O apoio matricial em Unidades de Saúde da Família: experimentando inovações em saúde mental. Saúde e Sociedade, São Paulo, v. 18, n. 1, p. 6374, jan./mar. 2009.

NEUBERG, S. L.; SMITH, D. M.; ASHER, T. Why people stigmatize: toward a biocultural framework. In: HEARTHERTON, T. F. et al. The social psychology of stigma. New York: The Guilford Press, 2003.

GRUPO 1. Projeto Construção Social da Aprendizagem acerca da Saúde Mental e Saúde da Família: grupo de discussão [maio 2008]. Moderadores: Rozemere Cardoso de Souza e Erika Antunes Vasconcellos. Jequié: Uesc: Fapesb, 2009, gravador digital. p. 1-21. Grupo de discussão produtor sobre a inserção da saúde mental na Estratégia de Saúde da Família.

GRUPO 2. Projeto Construção Social da Aprendizagem acerca da Saúde Mental e Saúde da Família: grupo de discussão [ago. 2008]. Moderadores: Rozemere Cardoso de Souza e Erika Antunes Vasconcellos. Ilhéus: Uesc: Fapesb, 2009, gravador digital. p. 1-20. Grupo de discussão produtor sobre a inserção da saúde mental na Estratégia de Saúde da Família.

GRUPO 3. Projeto Construção Social da Aprendizagem acerca da Saúde Mental e Saúde da Família: grupo de discussão [abr. 2008]. Moderadores: Rozemere Cardoso de Souza e Erika Antunes Vasconcellos. Vitória 
da Conquista: Uesc: Fapesb, 2009, gravador digital. p. 1-15. Grupo de discussão produtor sobre a inserção da saúde mental na Estratégia de Saúde da Família.

GRUPO 4. Projeto Construção Social da Aprendizagem acerca da Saúde Mental e Saúde da Família: grupo de discussão [maio 2008]. Moderadores: Josenaide Engracia dos Santos. Feira de Santana: Uesc: Fapesb, 2009, gravador digital. p. 1-13. Grupo de discussão produtor sobre a inserção da saúde mental na Estratégia de Saúde da Família.

GRUPO 6. Projeto Construção Social da Aprendizagem acerca da Saúde Mental e Saúde da Família: grupo de discussão [nov. 2008]. Moderadores: Josenaide Engracia dos Santos. Salvador: Uesc; Fapesb, 2009, gravador digital. p. 1-10. Grupo de discussão produtor sobre a inserção da saúde mental na Estratégia de Saúde da Família.

GRUPO 7. Projeto Construção Social da Aprendizagem acerca da Saúde Mental e Saúde da Família: grupo de discussão [abr. 2009]. Moderadores: Josenaide Engracia dos Santos. Ilhéus: Uesc: Fapesb, 2009, gravador digital. p. 1-10. Grupo de discussão produtor sobre a inserção da saúde mental na Estratégia de Saúde da Família.

FLORA, F. A. M. A crise na saúde mental. Revista de Psiquiatria Clínica. São Paulo, v. 35, n. 1, p. 33-34, 2008. Bimestral.

VASCONCELOS, E.M. Educação popular e a atenção a saúde da família. São Paulo: Hucitec, 2001.

VELHO, G. Projeto metamorfose: antropologia das sociedades complexas. Rio de Janeiro: Jorge Zahar, 2003. 


\section{บADIIUN?}

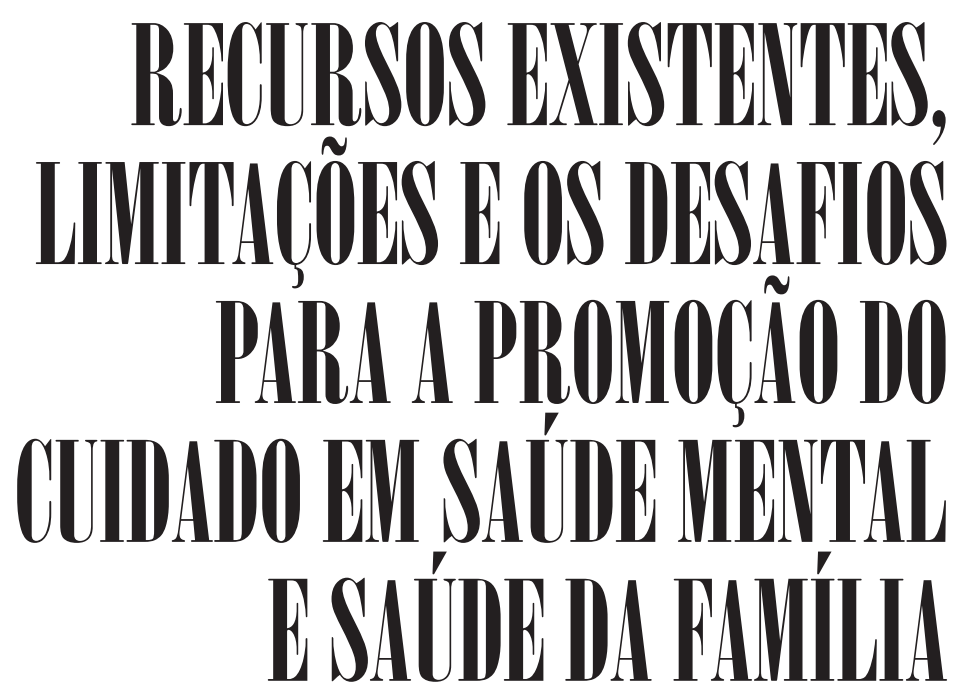

Josenaide Engracitia dos Sientos Briki Intunes Vasconcellos 
I

este capítulo, resumiremos os itinerários relatados pelas equipes de saúde da família e redes sociais envolvidas. Notamos, na pesquisa, que as narrativas são parecidas e mostram uma realidade uniforme na busca por cuidado. Os recursos da comunidade assistida pela equipe de saúde da família remetem à questão da integralidade e podem ser explicados por movimentos direcionados para que os usuários possam ter à sua disponibilidade um "cardápio" de ofertas de serviços nas redes formais e informais de saúde.

O objetivo de acessar os recursos do cuidado em saúde mental é desenvolver ações de mobilização de dispositivos comunitários, buscando construir espaços de reabilitação psicossocial, como oficinas, destacando-se a relevância da articulação intersetorial (conselhos tutelares, associações de bairro, grupos de autoajuda), a partir do campo de sociabilidades secundárias e do campo de seus cuidadores, como: recursos ambientais, espaços de lazer, organizações não governamentais (ONG) e igrejas.

Quando falamos de recursos utilizados e/ou com potencial de uso pelos profissionais da saúde da família, em especial, os agentes comunitários, remetemonos às múltiplas ações e recursos que estão mais próximos das pessoas e que constroem contatos e alianças, possibilitando melhora ou, então, estabilidade de quadros de sofrimento psíquico da comunidade.

Os recursos da comunidade utilizados por equipes da ESF para promoção de cuidado em saúde mental estão relacionados à rede social. Segundo Molina (2005), as redes sociais são compostas de fenômenos 
localizados tanto na esfera microssocial, relacionadas às interações entre os sujeitos, quanto na esfera macrossocial, na qual as redes são configuradas a partir das relações mais estruturadas em que estão imersas, como, por exemplo, as instituições - igrejas, áreas de lazer etc.

Um dos aspectos sociais relatados que interfere na saúde integral da comunidade é o lazer, conforme Martins, Santiago e Carvalho (2009). Não apenas se revela importante para a saúde física, como para o lúdico e para o desenvolvimento de práticas de socialização. Observamos, na pesquisa, que muitas áreas das equipes de saúde da família não dispõem de atividades e de equipamentos para este fim. Em um dos depoimentos, uma equipe fala da dificuldade: - São poucas as estratégias na comunidade. Olha o bairro aí fora, não tem espaço para área de lazer (GRUPO 6, 2008, p. 1-10).

A equipe percebe a necessidade de diversão como forma de integração na comunidade, para melhor qualidade de vida, um recurso importante na formação de alianças dentro da comunidade, o que pode favorecer a solidariedade.

A interação do indivíduo com sua rede social favorece a promoção da saúde. O apoio social se descreve pela oferta de informações e/ou auxílio material que produz mudanças positivas na qualidade de vida a grupos ou pessoas. Como refere Valla (1999, p. 10):

Um envolvimento comunitário pode ser um fator psicossocial significante na melhoria da 
confiança pessoal, da satisfação com a vida e da capacidade de enfrentar problemas. A participação social pode reforçar o sistema de defesa do corpo e diminuir a suscetibilidade à doença.

A importância das igrejas, enquanto estratégia informal de cuidado, é percebida nas falas como uma rede de apoio:

- Na minha área, tem uma igreja que faz cura interior e a gente manda vários pacientes. A cura interior diz que enquanto não cura o que está dentro, o externo também não vai curar (GRUPO 4, 2008, p. 1-13).

- Que em vez da gente ficar na igreja falando só ali, vamos fazer um culto lá na praça. Vamos buscar as caixas de som e falar (GRUPO 1, 2008, p. 1-21).

Os agentes comunitários utilizam a igreja como dispositivo de suporte de ajuda por entender que ela traz algum tipo de confiança e fortalece o vínculo para realização de atividades cotidianas. As igrejas se configuram, também, como rede de apoio por emprestarem seus espaços para a realização de grupos da unidade e aproximarem ainda mais a comunidade dos serviços de saúde. A utilização da igreja tem a ver com as crenças sobre os processos de adoecimento, mas representa as limitações das práticas tradicionais de atenção à saúde.

No contexto em que se desenvolveu a pesquisa com equipes de saúde da família do estado da Bahia, 
as redes de relações que se constroem no interior da área têm um peso significativo na vida de seus moradores. Daí, a necessidade de utilização das redes sociais (e a religião faz parte delas).

As atividades desenvolvidas no cotidiano são realidades construídas nas interações entre as pessoas dotadas de sentidos. A religião é um recurso muito utilizado pela comunidade e a equipe potencializa o recurso, na medida em que possa beneficiar a comunidade: - A religião tem ajudado muito, assim, lá naquela localidade, tão longe de tudo, de apoio, de tudo, a religião tem ajudado muito (GRUPO 3, 2008, 1-15).

Consoante Alves e Souza (1994), as concepções da doença, os recursos destinados para lidar com ela cotidianamente, bem como a escolha de tratamento emergem a partir de um complexo processo que envolve tanto a adesão dos sujeitos a certos modelos interpretativos, quanto as interações que se dão no interior das redes de relações dos indivíduos, que podem convergir ou não com esses repertórios interpretativos.

Outro dispositivo de uso no atendimento a situações de sofrimento mental, inserido no contexto da ESF, foi a terapia comunitária. Podemos considerá-la, sob a perspectiva de Mehry (2002), como tecnologia leve ou tecnologia de não equipamento ou de trabalho vivo.

Segundo depoimento da equipe, os profissionais foram capacitados para: tratar das preocupações com o cotidiano; expressar as emoções; a construção de redes sociais solidárias; a valorização do saber e da competência das pessoas; a corresponsabilidade e o resgate da capacidade de cura da comunidade. 
- O treinamento de terapia comunitária é uma estratégia. E agora, depois desse curso, me sinto mais capacitada para lidar com essas depressões leves, trabalhar com estes pacientes na terapia comunitária. Eu acredito que, pela proposta da terapia comunitária, podemos ter bons resultados com isto. Não é uma terapia que trata a doença, mas trata o sofrimento e o sentimento, trata o sintoma (GRUPO 4, 2008, p. 1-13).

Barreto (2005) conceitua a terapia comunitária como um procedimento terapêutico de caráter preventivo em saúde mental, pautado na atenção primária em saúde. Este é um processo que visa com que as pessoas partilhem entre si suas ansiedades, angústias, frustrações, sofrimentos e promovam a troca mútua de seus recursos e descobertas.

O acolhimento, outro dispositivo para o cuidado de saúde mental na ESF, conforme Neves e Rollo (2006), é o ato ou efeito de acolher. Expressa, em suas várias definições, uma ação de aproximação, um "estar com" e "perto de", ou seja, uma atitude de inclusão:

- Ela está muito desanimada, não quer almoçar, e eu fico levantando o ânimo dela.

Digo: - A senhora está forte e sua mente está boa. A senhora tem que levantar.

E ela diz: - Eu não vou sair mais desta cama. Aí eu digo: - Não, a senhora vai sair. Tudo é o pensamento e sua mente é forte. A senhora está boa.

Ela fica muito mais animadinha e diz: - L., diz que não vou ficar na cama, que vou andar. A gente precisa fazer isso (GRUPO 4, 2008, p. 1-13). 
Nesse trecho, portanto, percebem-se os atos da escuta, da produção de conversas e de vínculos - ações terapêuticas ou com potencial para este fim, mas que nem sempre são reconhecidas como possuidoras desse valor. Vejamos:

- Primeira coisa a fazer: nós temos que ter um bom relacionamento com a comunidade para que a comunidade se sinta à vontade e possa se manifestar, (para) que possamos compreender e perceber os problemas que eles têm e deixar espaço para que eles falem (GRUPO 5, 2009, p. 1-11).

\section{Outro recurso são as experiências socioculturais tecidas no cotidiano das comunidades:}

- Tem ações na comunidade que a gente utiliza as datas comemorativas para promover a saúde mental (GRUPO 4, 2008, p. 1-13).

- As datas festivas são importantes para a comunidade para tratar temas de saúde, como Dias das Mães, idosos, crianças, Dia da Saúde, lazer e atividade física. A gente usa centros comunitários (GRUPO 4, 2008, p. 1-13).

- Eu acho que dá (para cuidar da saúde mental), pois a gente já faz reunião, visita, palestra e tem a ver com promoção (desse cuidar) (GRUPO 7, 2009, p. 1-10).

- Faz palestras nas escolas, reuniões, e o trabalho é feito porque a gente não está esperando por ninguém. Vamos para associações, escolas, e quando vemos uma criança 
mais agitada conversamos com a professora (GRUPO 7, 2009, p. 1-10).

A escola é um dispositivo importante de provisão de atenção especial e as equipes de saúde da família têm feito a articulação com o ambiente escolar para reduzir situações de sofrimento:

- Eu queria só observar. O ano passado, eu estive, assim, muito presente no trabalho, na escola municipal que nós temos aqui e a diretora falou que estava assustada, porque a maioria das crianças estavam desenvolvendo algum distúrbio mental (GRUPO 5, 2009, p. 1-11).

Sobre o recurso das visitas domiciliares, com especial atenção para os casos/casas que constituem situações de maior vulnerabilidade, exemplificam-se as falas e interações sociais:

- Agente comunitário que vai, que bebe a água, que toma um cafezinho, um leite. $\mathrm{O}$ sol tinindo... E tem uma (pessoa) mesmo, dona M. que quer que você tome um leite quente toda vez que chega lá. Ela obriga a tomar um copo de leite. Por quê? (Porque o agente) é amigo, é você quem ouve (GRUPO 6, 2008, p. 1-10).

- Procurei entrar na casa que é uma sujeira, um lixo, e saber dele como ele vive, se alimenta. Ele disse que se alimenta com o filho na casa da família do irmão e mãe (GRUPO 6, 2008, p. 1-10).

Outra narrativa descreveu a articulação dos Centros de Atenção Psicossocial (Caps) com equipes 
da rede básica de saúde em seu território. Para essas equipes, o apoio recebido foi fundamental para o desenvolvimento do trabalho, conforme depoimentos abaixo:

- Tem esta orientação que é o pessoal do CAPS que dá à gente. Orientação que é prazerosa para a gente e para a comunidade. Fazemos visitas para convencer a família a tirar de dentro de casa o paciente (GRUPO 7, 2009, p. 1-10).

Sim, no caso, nós começamos (o cuidado com a saúde mental) com o pessoal do Caps (GRUPO 7, 2009, p. 1-10).

O Ministério da Saúde (BRASIL, 2004) define como um dos objetivos da integração do Caps com equipes da atenção básica a realização de apoio matricial, isto é, fornecer-lhes orientação e supervisão, atender conjuntamente situações mais complexas, realizar visitas domiciliares e atender casos complexos, por solicitação das equipes.

Um dos recursos de cuidados aprendido no cotidiano na comunidade são as habilidades para agir de modo criativo, principalmente através das conversas, exemplificadas na frase: - Recursos nenhum. Só a lábia, só a conversa (GRUPO 4, 2008, p. 1-13).

O recurso da conversa é construído a partir de um saber prático. Segundo Ayres (2004), esse saber tem caráter contingente, ou seja, lida com a eventualidade, com a incerteza, com os acontecimentos e experiências humanas, não lida com aspectos perenes, causais e universais, não é um saber que produz 
objetos, artefatos ou instrumentos. Por isso o grupo não considera tão importante o recurso, já que o conceito de êxito técnico está estreitamente ligado ao conceito de sucesso prático. Esse se volta para o valor que a ação de saúde tem para sujeitos e populações, engloba um conjunto de implicações simbólicas, relacionais e materiais das intervenções e recomendações de saúde na vida cotidiana dos sujeitos.

Para Ayres (2004) é um saber nem sempre cumulativo e que pode emergir de experiências, de interesses comuns ou divergentes, de tensões e de possibilidades de interação. Nesse sentido, não há menos verdade nesse saber, mas, menos certeza e determinação. Trata-se de construção da busca sobre a compreensão da vida, das experiências e escolhas diante das diversas contingências confrontadas no cotidiano:

- Agente comunitário que vai, que bebe a água, que toma um cafezinho. É amigo, é quem ouve (GRUPO 6, 2008, p. 1-10).

As experiências vividas pela equipe em seu cotidiano renovam sua compreensão e repercutem nas propostas que desenvolvem:

- A gente vai fazendo e aprende a fazer as coisas nas práticas, erra nas práticas, e a partir das vivências que nós tivemos, a gente sistematiza no dia a dia (GRUPO 5, 2009, p. 1-11).

É preciso que os profissionais da equipe prestem atenção para o conhecimento prático da vida cotidiana, pois conforme Souza (1999) é a nossa relação primordial com o mundo que fundamenta qualquer 
conhecimento. Identificamos o que esse autor refere no que ouvimos no relato cotidiano das equipes de saúde da família investigadas, nos trechos de conversas citados, que dão sentidos aos movimentos, dentre eles, a conversa terapêutica, a ida às escolas e o uso de festas culturais.

Ainda consoante Souza (1999), é no mundo que se vive e se constitui o solo para toda atividade de conhecimento e Schutz (1979) afirma que o conhecimento do senso comum, apesar de suas insuficiências, basta para que nós nos entendamos com o próximo, os objetos culturais e as instituições: a realidade social. A nosso ver, as múltiplas versões dessa realidade.

As limitações dos recursos de cuidado em saúde mental no território da ESF poderão surgir em espaços onde ocorrem as suas potencialidades. Exemplo: a igreja pode ser um itinerário terapêutico, assim, como pode ser também um lugar de adoecimento:

- Muita igreja evangélica acaba fazendo tipo uma lavagem cerebral. Deixa a pessoa mais doida. Aí, se ele não é forte de mente, ele acaba ficando com problema mental (GRUPO 3 , 2008, 1-15).

A sobrecarga profissional é outra situação relatada pela equipe de saúde da família que limita a produção de cuidado em saúde mental:

- Se ficar uma criança sem pesar, eu tenho que dizer o porquê eu não pesei. Pode ter uma vaca que não me deixou passar, ou um cachorro. Então, e aí? Eu tenho tempo? Eu tenho que ter espaço. A minha cabeça tem 
que estar preparada pra isso. Será que eu tenho condições? Ou então colocando mais problemas para mim também vou me tornar doente. É isso que eu quero saber. Senão, eu vou ficar mais doida que os doidos (GRUPO 3, 2008, p. 1-15)

- A gente é tipo um pneu de socorro. Tudo, mesmo sem entender, a gente tem que ir lá, tem que enfrentar (GRUPO 3, 2008, p. 1-15).

- [O processo de trabalho] estressa quem trabalha, estressa quem cuida, estressa o doente (GRUPO 3, 2008, p. 1-15).

- Eu estou estressada, vou levar o quê pra ela? Se ela perceber que eu estou com a minha fisionomia ruim. Então, você está ali morrendo, mas você tem que mostrar uma boa aparência para a pessoa. Tem dia que eu não estou aguentando, que eu estou assim (GRUPO 3, 2008, p. 1-15).

\section{O conflito aparece, principalmente, na dinâmica da prática cotidiana:}

- Hoje, eu tenho 154 problemas diferentes que acompanho e cada um tem uma história diferente para contar (GRUPO 6, 2008, p. 1-10).

- Às vezes, o agente comunitário fica mais doido do que a comunidade. Cada agente tem sua comunidade para tomar conta e cada uma tem uma coisa diferente e tem que ouvir um pouco de cada um, com diferentes necessidades de atenção, e a gente quer ajudar, como um que conta que o marido traiu e o outro diz 
que a mulher (traiu) e diz que vai matar ela e a gente ouve todo tipo de coisa (GRUPO 5, 2009, p. 1-11).

Agentes Comunitários de Saúde (ACS) são os profissionais mais expostos aos dramas familiares dos usuários, já que sua principal função é a visita domiciliar. São profissionais com intensa sobrecarga emocional. Muitos deles entram em sofrimento psíquico, sem conseguir separar o pessoal do profissional. Demanda de cuidado à equipe para posterior atenção à comunidade: - Acho que nós éramos pra ser tratados primeiro, para depois tratar o povo. É preciso cuidar da gente (GRUPO 6, 2008, p. 1-10).

A ineficácia do sistema de referência e contrarreferência é, também, relatado como impedimento na utilização dos equipamentos das redes nos territórios da ESF:

- Sim. A nossa grande dificuldade, na verdade, é referência. É como referenciar. Primeiro lugar, a gente não sabe o que fazer com estes pacientes... Ele tem outras doenças, outros problemas clínicos e eles não vêem de forma integral. Ele é um paciente psiquiátrico, mas tem outras doenças (GRUPO 4, 2008, p. 1-13).

- Aqui nós temos o Caps I, II e III. Cada um com sua área e "Ad" que é álcool e drogas, o "I" que é infantil, Caps I que é o apoio pedagógico. Nós temos na área autismo, hiperatividade que não é a grande loucura. São situações de sofrimento mental que a equipe não está preparada para atender e 
não tem para onde encaminhar (GRUPO 4, 2008, p. 1-13).

Na pesquisa, percebemos que os recursos utilizados fazem parte da rede. Conforme Bonet e Tavares (2006), rede é o mecanismo, o instrumento para descrever o mundo. Mundo feito pelos mediadores e suas agências; nos termos de Latour (2006), uma cadeia de ações em que cada participante deve ser tratado como mediador. As associações que se estabelecem nas redes não se fazem apenas com sujeitos, mas também com os chamados não humanos. Para Law (2002), se os seres humanos formam uma rede social, é porque eles interagem com outros indivíduos e com outros materiais. Ou seja, o campo do cuidado da saúde na ESF, como vimos, não se restringe à unidade de saúde, pois parte importante dos atores está localizada em campos de sociabilidade da sociedade civil (associações voluntárias, ONG) e na esfera privada, (as redes de sociabilidade primária - família, vizinhos, amigos), o que sinaliza a necessidade de maior investimento em estratégias de integralidade e intersetorialidade focadas na autonomia e na promoção da saúde, que possam produzir diferenças e gerar transformações no cuidado à saúde.

\section{Referências}

ALVES, P.; SOUZA, I. Escolha e avaliação de tratamento para problemas mentais: o itinerário terapêutico. In: ENCONTRO ANUAL DA ASSOCIAÇÃO NACIONAL DE PÓS-GRADUAÇÃO E PESQUISA EM CIÊNCIAS SOCIAIS (ANPOCS), 18., 1994, Caxambu. Anais... Caxambu: Anpocs, 1994. Mimeografado. 
RES, J. R. C. M. Care and reconstruction in healthcare practices. Interface. Comunicação, Saúde, Educação, Botucatu, v. 8, n. 14, p. 73-92, set. 2003- fev. 2004.

BARRETO, A. P. Terapia comunitária passo a passo. Fortaleza: Gráfica LCR, 2005.

BONET, O. A. R.; TAVARES, F. R. G. Redes em redes: dimensões intersticiais no sistema de cuidados a saúde. In: PINHEIRO, R.; MATTOS, R. A. Gestão em rede: práticas de avaliação, formação e participação na saúde. Rio de Janeiro: CESPESC, 2006.

BRASIL. Ministério da Saúde. Secretaria de Atenção a Saúde. Núcleo Técnico da Política Nacional de Humanização. Acolhimento nas práticas de produção de saúde. 2. ed. Brasília, DF: Ministério da Saúde2006. (Série B. Textos básicos em Saúde).

Departamento de Ações Programáticas Estratégicas. Saúde mental no SUS: os centros de atenção psicossocial. Brasília, DF: Ministério da Saúde, 2004.

GRUPO1. Projeto Construção Social da Aprendizagem acerca da Saúde Mental e Saúde da Família: grupo de discussão [maio 2008]. Moderadores: Rozemere Cardoso de Souza e Erika Antunes Vasconcellos. Jequié: Uesc: Fapesb, 2009, gravador digital. p 1-21. Grupo de discussão produtor sobre a inserção da saúde mental na Estratégia de Saúde da Família.

GRUPO 3. Projeto Construção Social da Aprendizagem acerca da Saúde Mental e Saúde da Família: grupo de discussão [abr. 2008]. Moderadores: Rozemere Cardoso de Souza e Erika Antunes Vasconcellos. Vitória da Conquista: Uesc: Fapesb, 2009, gravador digital. p. 
1-15. Grupo de discussão produtor sobre a inserção da saúde mental na Estratégia de Saúde da Família.

GRUPO 4. Projeto Construção Social da Aprendizagem acerca da Saúde Mental e Saúde da Família: grupo de discussão [maio 2008]. Moderadores: Josenaide Engracia dos Santos. Feira de Santana: Uesc: Fapesb, 2009, gravador digital. p. 1-13. Grupo de discussão produtor sobre a inserção da saúde mental na Estratégia de Saúde da Família.

GRUPO 5. Projeto Construção Social da Aprendizagem acerca da Saúde Mental e Saúde da Família: grupo de discussão [maio 2009]. Moderadores: Josenaide Engracia dos Santos. Salvador: Uesc: Fapesb, 2009, gravador digital. p. 1-11. Grupo de discussão produtor sobre a inserção da saúde mental na Estratégia de Saúde da Família.

GRUPO 6. Projeto Construção Social da Aprendizagem acerca da Saúde Mental e Saúde da Família: grupo de discussão [nov. 2008]. Moderadores: Josenaide Engracia dos Santos. Salvador: Uesc; Fapesb, 2009, gravador digital. p. 1-10. Grupo de discussão produtor sobre a inserção da saúde mental na Estratégia de Saúde da Família.

GRUPO 7. Projeto Construção Social da Aprendizagem acerca da Saúde Mental e Saúde da Família: grupo de discussão [abr. 2009]. Moderadores: Josenaide Engracia dos Santos. Ilhéus: Uesc: Fapesb, 2009, gravador digital. p. 1-10. Grupo de discussão produtor sobre a inserção da saúde mental na Estratégia de Saúde da Família.

LATOUR, B. Jamais fomos modernos. Rio de Janeiro: Ed 34, 2006. 
LAW, J. After ANT: complexity, naming and topology. In: LAW, J.; HASSARD, J. Actor network theory and after. Oxoford: Blackwell, 2002.

MARTINS, P. H.; SANTIAGO, M.; CARVALHO, R. A cidadania como afetividade: a luta pela autoconfiança. In: PINHEIRO, R.; MARTINS, N. H. P. (org). Avaliação em saúde na perspectiva do usuário: abordagem multicêntrica. Rio de Janeiro: CEPESC/IMS-UERJ; Recife: Editora Universitária; São Paulo: ABRASCO, 2009.

MERHY, E. E. Saúde: a cartografia do trabalho vivo. São Paulo: Hucitec, 2002.

MOLINA, J. L. El estudio de las redes personales: contribuciones,

métodos y perspectivas. Empiria, Barcelona, v. 10, p. 71106, jul./dic. 2005.

SCHUTZ, A. Fenomenologia e relações sociais. Rio de Janeiro: Zahar, 1979.

SOUZA, I. M. Na trama da doença: uma discussão sobre redes sociais e doença mental. In: RABELO, M. C.; ALVES, P. C.; SOUZA, I. M. Experiência de doença e narrativa. Rio de Janeiro: Fiocruz, 1999.

VALLA, V. V. Educação popular, saúde comunitária e apoio social numa conjuntura de globalização. Cadernos de Saúde Pública, Rio de Janeiro, v.15, p. 7-14, 1999. Suplemento 2. 

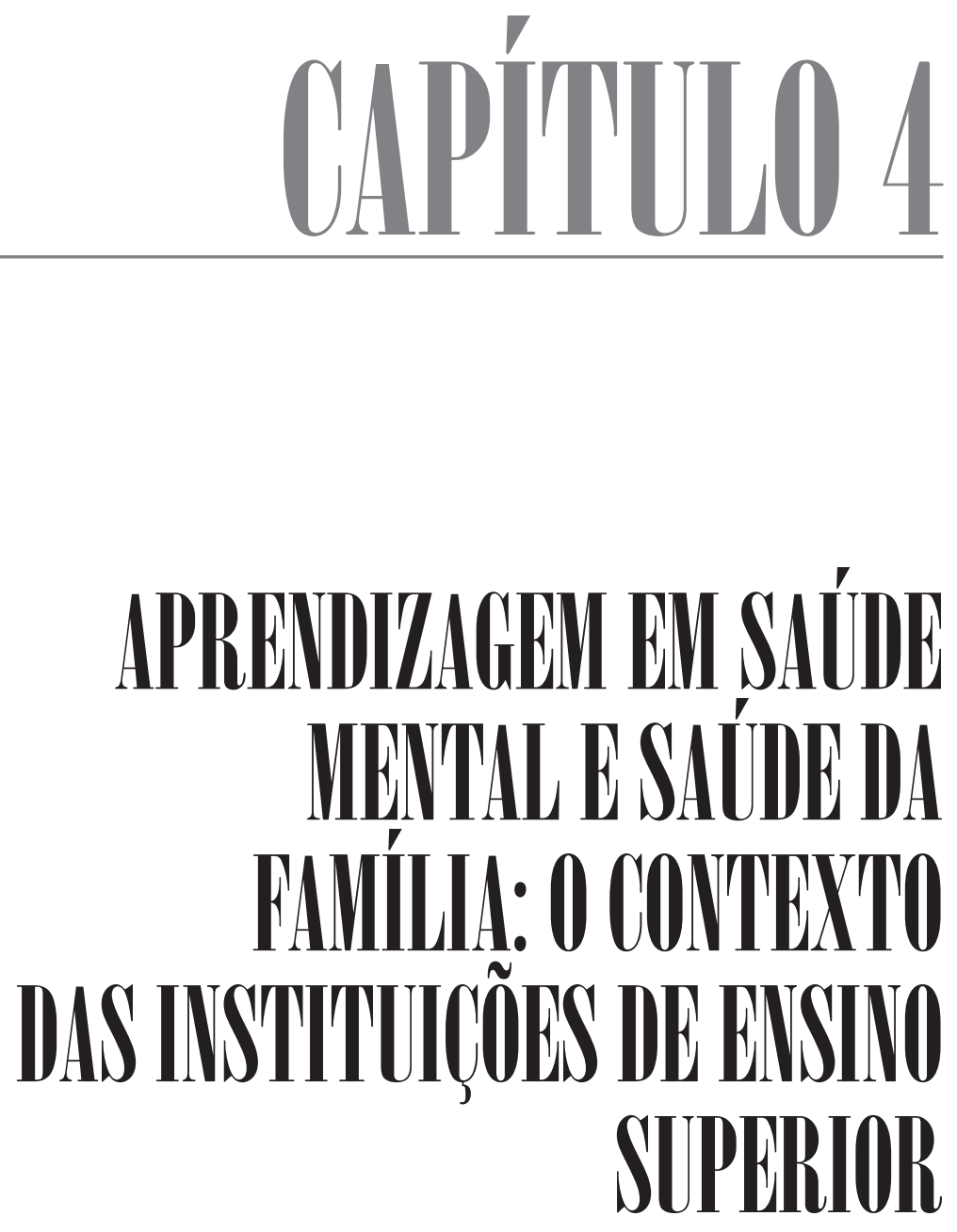

João Nendes de Limina Júnior Vairian Iloritis Caldass Déboria Cristiane Silva Flores Lino 
【

m dos grandes desafios para a sustentação das políticas públicas diz respeito à formação de profissionais com competências e habilidades para apropriação teórica e técnica, sem a qual é difícil avançar na consolidação de tais políticas. Este fato torna-se mais delicado quando os rumos da política são orientados por uma forte base conceitual-ideológica, como é o caso da saúde mental, cuja decisão quase sempre é perpassada pela ideologia que, não necessariamente, esteve estampada nos aportes teóricos.

Sem dúvida, a loucura, como uma construção social, esteve sempre tomada por ideologias decorrentes dos processos sociais em determinados contextos históricos. Isso significa dizer que, para além da necessidade de formar teórica e tecnicamente um profissional no campo da saúde mental, trata-se, antes de tudo, de desconstruir e construir ideologias sobre a loucura, considerando todos os sentidos que esse debate comporta.

O sentido é resultante de uma construção social decorrente das muitas interações entre o sujeito e seu contexto, pessoas e situações. Segundo Spink e Medrado (1999, p. 41), é por meio do sentido construído que as pessoas "constroem os termos a partir dos quais compreendem e lidam com as situações e [os] fenômenos a sua volta". O sentido construído passa a ser o elemento que norteia a interpretação, por um lado, e a ação, por outro.

Como se não bastassem os desafios inerentes ao processo de aprendizagem em saúde mental, nas últimas décadas, as universidades brasileiras vêm sofrendo uma pressão externa no sentido de dar primazia à 
formação de profissionais numa lógica em que os determinantes são ditados pelas necessidades do mercado de trabalho (SANTOS, 2005). Isso implica em comprometimento à produção de conhecimento em determinadas áreas que não são do interesse do mercado.

Nessa lógica, a saúde mental na perspectiva da reforma da atenção psiquiátrica - antimanicomial, desinstitucionalizada - certamente corresponde a uma das áreas de menor investimento de recursos e de menos interesse para o mercado, dando a temática um caráter periférico dentro dos currículos brasileiros.

Questiona-se, pois, como abordar o problema considerando a dimensão ideológica que o debate encerra e, por outro lado, como descolar a saúde mental da condição periférica à qual foi submetida nos currículos acadêmicos, trazendo-a para o centro da formação, uma vez que pode ser considerada um dos grandes eixos transversais da saúde, conforme afirma Lima Júnior et al. (2010).

Sabendo da delicadeza e da sensibilidade que o tema exige, algumas ações conjuntas do Ministério da Saúde e do Ministério da Educação tentam construir políticas reparadoras para as lacunas, no tocante à formação e à ampliação do número de trabalhadores para saúde mental. Um exemplo é o Programa de Educação pelo Trabalho para a Saúde/Saúde Mental, Crack, Álcool e Outras Drogas (PET-Saúde/Saúde Mental Crack). São necessários recursos humanos capazes de superar o paradigma da tutela do louco e da loucura, o que exige, cada vez mais, da formação dos trabalhadores (BRASIL, 2005). 
O relatório da Coordenação Nacional de Saúde Mental, Álcool e Outras Drogas dedica um capítulo inteiro sobre o tema (BRASIL, 2011), apresentando ações estruturantes como a ampliação do aporte financeiro para educação permanente, a criação de residências multiprofissionais em saúde mental, ampliação do número de PET-Saúde/Saúde Mental Crack.

Atualmente, há uma crescente preocupação na diversificação da produção de conhecimento em saúde mental, historicamente concentrada em dois eixos temáticos: ensaios farmacológicos e ensaios diagnósticos (BRASIL apud CAMPOS; FURTADO, 2006). Com a ampliação dessa produção, tanto no que diz respeito ao volume de publicações quanto no que tange aos objetos estudados, alguns estudos analisam a formação de profissionais ou de categorias específicas como o caso da Enfermagem, Medicina e Psicologia.

Estudo realizado por Lucchese (2007) com docentes que ministram disciplinas de Enfermagem voltadas ao campo da saúde mental revela que, embora se verifique algum esforço no sentido de mudança do cenário, os profissionais da enfermagem - importantes articuladores do processo da reforma psiquiátrica - ainda reproduzem os velhos paradigmas da saúde mental, identificado através das metodologias utilizadas e de alguns discursos.

Considerando que não se trata de uma situação isolada numa determinada região do país, há indícios, identificados por estudos realizados no Brasil, convergindo para a identificação dessa fragilidade (SOUZA; MATIAS; GOMES, 2007; OLIVEIRA; ALESSI, 2003). 
Ceccin e Feuerwerke (2004) nos remetem a uma dimensão bastante singular quando se trata da formação de profissionais que, posteriormente, exercerão suas funções numa proposta como a do SUS. São requeridas condições na constituição do currículo que estejam muito além da composição formal da relação transmissão/aquisição. Assim, espera-se que as academias estejam sensibilizadas para o seguinte:

[...] projeto educativo que extrapola a educação para o domínio técnico-científico da profissão e se estende pelos aspectos estruturantes de relações e de práticas em todos os componentes de interesse ou relevância social que contribuam à elevação da qualidade de saúde da população (CECCIM; FEUERWERKE, 2004, p. 42).

No que tange às singularidades da formação em saúde mental - a necessidade de contemplação de aspectos sensíveis como a escuta qualificada, a clínica na perspectiva ampliada, o acolhimento, o encontro respeitoso, a necessidade de empoderamento do usuário, a urgência do protagonismo dos sujeitos portadores de sofrimento mental, sendo o próprio cuidado enquanto "episteme" e "práxis" - constata-se certo empobrecimento na formação dos profissionais. Empobrecimento que não só afeta a saúde mental como toda a formação em saúde, pois a clínica do vínculo e a responsabilização de cuidados não são objetos relevantes de estudos nas faculdades da área (LOBOSQUE, 2007).

Embora se verifiquem, ainda, muitos obstáculos a serem superados, é inegável os esforços das universidades brasileiras para reformulações dos currículos 
convergentes para a formação comprometida com o Sistema Único de Saúde (SUS). Em saúde mental, pode-se verificar tal avanço a partir das novas diretrizes curriculares postas para a formação de profissionais de algumas áreas relevantes para a consolidação da reforma da atenção psiquiátrica, tais como: Enfermagem, de acordo com a Resolução CNE/CES N. ${ }^{\circ} 3$, de 7 de novembro de 2001 (BRASIL, 2001), e Psicologia, conforme a Resolução CNE/CES N. ${ }^{\circ} 8$, de 7 de maio de 2004 (BRASIL, 2004).

É nesse cenário polissêmico de permanências e rupturas, de acordos e desenlaces, de avanços e retrocessos, vanguardas e anacronismos que se desenha o processo de formação em saúde mental no Brasil. Provavelmente, o que há de comum em tudo isso é a constatação de que, em primeiro lugar, o objeto da saúde mental é complexo por natureza e é assim que deve ser abordado. Em segundo lugar, qualquer visão parcial tende a produzir uma deformação, uma vez que "toda simplificação de um problema acarreta necessariamente sua falsificação", como disse Lobosque (2007, p. 42), significando que o campo da saúde mental estará posto sempre num certo território de tensionamento.

Nesse sentido, o presente capítulo discorrerá sobre um dos desafios da reforma da atenção psiquiátrica, que é a formação dos profissionais de saúde para atuação no âmbito da saúde mental e da Estratégia de Saúde da Família. Assim, buscará refletir sobre o contexto das instituições de ensino superior, especialmente, o da formação de médicos e de enfermeiros, buscando perceber as práticas discursivas referentes ao objeto em questão. 
O referencial teórico baseia-se na compreensão teórica do construcionismo social, perspectiva que considera que as práticas discursivas são socialmente construídas, sempre contextualizadas dentro de uma cultura, capazes de promover a possibilidade de reconstrução de realidades e práticas, num movimento dinâmico, vivo, mutável, sendo base para uma contínua compreensão dos discursos como algo social e historicamente determinado.

\section{A saúde mental no contexto da formação de profissionais da medicina e da enfermagem nas universidades públicas da bahia}

O debate que se segue faz um recorte dos dados coletados com docentes de várias áreas e que ministram disciplinas ou componentes curriculares nos quais abordavam a temática da saúde mental. Os sujeitos dessa amostra, nove ao todo, são docentes das universidades públicas baianas estaduais (Uneb, Uefs e Uesb) e de uma universidade federal (UFBA), que atenderam ao critério mínimo de atuar há mais de um ano com essa temática. Os elementos discursivos destacados para fins de análise foram: a aprendizagem e suas implicações para a reforma da atenção psiquiátrica; a existência de ações interdisciplinares no âmbito das instituições de ensino; projetos de pesquisas e de extensão em saúde mental; tecnologias de ensino/ aprendizagem; práticas discursivas sobre saúde mental e saúde da família.

Buscando compreender a diversidade das práticas discursivas dos sujeitos entrevistados sobre o 
tema em tela, procuramos não dicotomizar as diferentes concepções, tendo o cuidado, ainda, de não criar um crivo de verdade ou de sentido único. Isso apenas produziria uma cristalização semântica e em nada auxiliaria a compreensão dos múltiplos sentidos - polissemia - e da dinâmica de cenários complexos do campo da saúde mental.

Embora as entrevistas tenham sido realizadas individualmente, partiu-se do pressuposto de que o sentido seja um atributo socialmente construído (SPINK, 2003). Trata-se de uma tentativa de explicitação dos processos pelos quais as pessoas explicam e dão sentido ao que fazem. Isso difere em muito da tentativa de encontrar convergência que permita criar um parâmetro generalizável de verdade a ser posto como norma.

Dessa forma, considerando a diversidade de contextos e de cenários tanto das políticas públicas quanto das universidades brasileiras, a análise decorrerá da identificação de permanências e rupturas entre as similaridades e singularidades que caracterizam a diversidade da produção de sentidos nesta pesquisa.

Em geral, o contexto e os sujeitos dessa produção caracterizam-se por apresentarem: a) diversidade na formação profissional dos docentes (médicos(as), enfermeiros(as), psicólogos(as) e assistentes sociais) responsáveis pelas disciplinas de saúde mental nos cursos de Enfermagem e Medicina. Ao lado desse fato, verificamos ainda a existência de profissionais com formação em distintas abordagens teóricas, tais como: Psicanálise, Homeopatia, Psicologia Social e da Saúde (psicólogos); b) diferentes pontos de vista 
sobre o processo e o sucesso da reforma da atenção psiquiátrica. As perspectivas variam desde a convicção do sucesso até os que concordam com a reforma da atenção psiquiátrica, mas com a desconfiança de que não acontecerão grandes avanços; c) um cenário político-pedagógico (nas universidades públicas baianas) bastante heterogêneo; há matrizes curriculares tradicionais que organizam os conteúdos em disciplinas, reproduzindo o modelo da fragmentação da aprendizagem; no caso da saúde mental, ela é vista de modo repicado como temática diluída em uma ou duas disciplinas. Contudo, há também universidades que têm os currículos organizados em ciclos de aprendizagem onde a saúde mental é vista numa lógica de integralidade no diálogo com várias outras demandas em saúde. Verificamos a existência de diferenças significativas também no tocante à metodologia dos cursos. Há desenhos metodológicos em que as aulas são tradicionais ou expositivas, sendo que em outros cursos as metodologias são participativas e problematizadoras. Os docentes das universidades com metodologias ativas tenderam a compreender a reforma da atenção psiquiátrica com a incorporação da saúde mental na saúde da família de modo mais confiante; d) cursos com organização modular de conteúdos em que há uma maior articulação dos temas referentes à saúde mental com o conjunto da formação, ou seja, produz-se menos fragmentação entre os conteúdos. Uma constatação comum foi que, com a necessidade de formação generalista, os cursos não possuem disciplinas específicas para saúde mental. A temática comumente é dissolvida em disciplinas tais como: Psicologia Médica, Psicologia Aplicada à Saúde, 
disciplinas afins para a residência médica, ou em módulos transversais em alguns cursos.

\section{A aprendizagem e suas implicações para a reforma psiquiátrica}

O sucesso de uma política pública requer um conjunto de pessoas com competências e habilidades que, transformadas em práxis, tornem viável a concretização e a consolidação do novo modelo que surge. Isso é ainda mais evidente quando se trata de questões de caráter paradigmático. Nesse sentido, a formação dos novos profissionais deve ser considerada como um dos aspectos decisivos no processo. De acordo com Krausz (1997, p. 152), as instituições formadoras têm uma cota de implicação para o sucesso da política de saúde uma vez que,

no caso específico da Saúde Pública, a Universidade tem um papel crucial na formação de recursos humanos; papel este que tem sido objeto de muitas discussões e debates em virtude da importância que esses recursos humanos representam, não apenas nas ações de saúde propriamente ditas, como também na própria definição da política de saúde a ser seguida. Daí decorre a necessidade de rever constantemente os programas de formação de recursos humanos para a Saúde Pública, com o intuito de oferecer um preparo adequado aos papéis que estes irão exercer nos diferentes escalões institucionais.

A relevância da formação de recursos para a saúde mental é um aspecto reconhecido pelo próprio 
Ministério da Saúde que considera ser esse um dos grandes desafios à consolidação da reforma psiquiátrica (BRASIL, 2005).

Os entrevistados aqui também reconhecem que as diretrizes que determinam a formação profissional correspondem a um fator decisivo para o sucesso da reforma da atenção psiquiátrica:

- Aqui, nós estamos formando os profissionais que vão se formar e depende da universidade e da gente, dos profissionais que estão aqui, formar essa nova mentalidade (ENTREVISTADO 3, 2009, p. 1-5).

Nesse aspecto, o projeto pedagógico da instituição acaba sendo um dispositivo estratégico para garantir o pacto com a formação de mão de obra qualificada, bem como a formação de profissionais comprometidos com a sustentação da política de reforma da atenção psiquiátrica. Ou seja, não basta apenas instrumentalizar teoricamente, trata-se de enfatizar o compromisso com a política pública vigente. Assim, ocorre um processo dialético em que a universidade se transforma e vai também transformando seu jeito de fazer.

- Com essa mudança de paradigma, a gente diz assim, questionando o serviço, porque o profissional nosso, o profissional que a gente está formando já que a gente é uma instituição de ensino superior que forma pessoas que vai trabalhar na rede de saúde mental (ENTREVISTADO 7, 2008, p. 1-5).

O processo de formação passa a assumir uma condição sine qua non para a reforma da atenção 
psiquiátrica, o que traz consigo a existência de uma relação de implicação entre a instituição e, consequentemente, a formação dos profissionais e as políticas públicas. Alguns dos entrevistados acreditam que esta compreensão deve ser vista como condicionante para o sucesso nas políticas de saúde mental.

Uma aliança necessária, quase que devia ser até um [...] Uma condição, para que a gente não corra o risco de acontecer aquilo que eu falei (fazer referência ao que foi dito) [...] e assim [...] Uma condição, essa articulação da universidade (com quem?) (ENTREVISTADO 2, 2008, p. 1-10).

A lógica da "aliança" sintetiza bem a necessidade da articulação entre a formação profissional e as políticas públicas em saúde mental. Criar um laço, articular, atrelar, aliar a formação com as necessidades das políticas públicas. Essa é uma importante estratégia para, definitivamente, mudar uma cultura que, historicamente, se configurou nas academias brasileiras caracterizadas por certo descompasso entre a formação profissional e as demandas dos setores públicos.

\section{Ações interdisciplinares no âmbito das instituições de ensino}

O cenário dos modelos e estratégias institucionais dos sujeitos entrevistados apresenta uma realidade bastante heterogênea. Se há certo consenso no que tange ao reconhecimento da importância da formação profissional como fator decisivo para o sucesso das 
políticas de saúde mental, por outro lado, no que diz respeito ao modo como isso se processa na prática, verifica-se a existência de uma significativa diversidade. Existem instituições nas quais a formação em saúde mental se dá de modo ainda fragmentado em momentos esporádicos, em disciplinas que não dialogam entre si; mas há também algumas que conseguem inserir articuladamente a temática da saúde mental, criando um elo entre diferentes disciplinas ou módulos.

A discussão sobre saúde mental ainda é feita em algumas universidades de modo fragmentado. Além disso, o ensino ocorre apenas em disciplinas estritamente voltadas ao núcleo de saber, ou seja, a discussão não atravessa ou transversaliza o contexto da formação profissional, ficando limitada às disciplinas clássicas, tais como: Enfermagem Psiquiátrica, Saúde Mental e Psicopatologia.

Não [há] outras disciplinas em Enfermagem que possam abordar a questão. A discussão é incluída em disciplinas afins. E a gente também não tem feito de uma forma articulada (ENTREVISTADO 7, 2009, p. 1-15).

Já existem movimentos no sentido de articular ou agregar a saúde mental ao conjunto de várias disciplinas, ou mesmo de ações voltadas a outros dispositivos que garantam o diálogo com a saúde mental. Diga-se de passagem, que essa modalidade de arranjo institucional prevaleceu entre os entrevistados. A maioria das instituições esboça sinais dessa interface.

Verificamos, ainda, que algumas experiências interdisciplinares abrem a possibilidade de inclusão 
para a participação de discentes de cursos que, historicamente, se implicam de maneira discreta no campo da saúde mental. Tal possibilidade traz um ganho não somente pelo quantitativo de profissionais de diferentes áreas, mas principalmente por novos olhares sobre o objeto da saúde mental, impactando as práticas de cuidado, elevando o deslocamento do debate da perspectiva estrita do transtorno mental:

Inclusive, esse pessoal de lá e de outros departamentos que trabalham também com essa área estão se inserindo nesse projeto que são [...] as tecnologias assistidas a idosos portadores de Parkinson. [...] Inclusive de alunos do curso de Fisioterapia, de Educação Física (ENTREVISTADO 1, 2008, p. 1-11).

No contexto das instituições que possuem estratégias de articulação e interdisciplinaridade na saúde mental, verificam-se dois cenários: a) há instituições que têm em seu projeto pedagógico o compromisso assumido com a garantia da interface entre as várias áreas do conhecimento; b) entretanto, em outras entrevistas, fica evidenciado que essas ações não correspondem, necessariamente, a metas institucionais postas no projeto político-pedagógico, mas decorrem do esforço e dedicação de alguns atores/atrizes implicados diretamente com a discussão.

Cenário "a”

- Claro. A interface [...] é porque a saúde mental na verdade, agora com essa nova legislação curricular a partir da LDB, que é a Lei de Diretrizes e Bases, a gente está tendo 


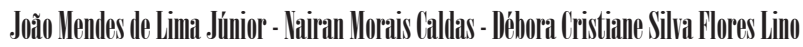

todo o [...] projeto político pedagógico (ENTREVISTADO 6, 2008, p. 1-10).

Cenário "b"

- Olha, tenho algumas ideias, mas nada fechado ainda, principalmente porque, como eu digo pra vocês, a primeira disciplina de Psicologia [...] Ela é bem básica e ela é para dar noções básicas mesmo do que é, e aí eu preciso trabalhar a idéia do amadurecimento dos alunos, para ver se eles estão prontos para isso então, o que eu pensei foi, caso essa disciplina seja realmente desmontada para o semestre que eu estou propondo que eles já começam a ter contato com o paciente, então ai é possível criar uma parceria para esses professores que estão acompanhando essa prática (ENTREVISTADO 3, 2008, p. 1-5).

Em todo caso, dada a complexidade do objeto da saúde mental, a interdisciplinaridade acaba sendo, ao mesmo tempo, causa e consequência. Cabe às instituições de ensino o reconhecimento das interfaces desse objeto e, em função delas, criar condições para que, efetivamente, sejam construídas estratégias para que a formação profissional consiga ser sensível ao ponto de alcançar a característica sutil desse objeto. Contudo, a partir das entrevistas produzidas, verificamos que o debate sobre saúde mental mostra francos sinais de caminhar rumo a uma compreensão interdisciplinar e continua centrado nas práticas de saúde. Não se verificou qualquer registro de ação ou mesmo esboço de intenção para um diálogo interdisciplinar com áreas de campos de afinidade, como as humanidades ou as ciências sociais. Isso também é revelador 
do zeitgeist atual. A partir de evidências como essas, podemos repensar os passos futuros para a organização da interdisciplinaridade no processo de formação profissional para o campo da saúde mental.

\section{Projetos de pesquisa e de extensão em saúde mental}

No âmbito dos pilares da pesquisa e da extensão em saúde mental, nas instituições de ensino universitário, acontece um fenômeno que revela certa fragmentação em relação à articulação entre ensino, pesquisa e extensão. Dos sujeitos entrevistados, apenas dois dizem que a instituição não possui atividades acadêmicas dessa natureza. Todos os demais dizem que a instituição realiza pesquisa e extensão em saúde mental. Do conjunto das respostas, verifica-se em apenas uma a relação entre os três pilares da universidade:

- Mas assim, sempre buscando integrar ensino, pesquisa, extensão dentro da disciplina, sempre enfocando a construção do conhecimento [...] (ENTREVISTADO 7, 2008, p. 1-15).

Quando se investigaram as temáticas ou os objetos de estudos dos demais sujeitos, constatou-se a diversidade no que diz respeito ao interesse e, também, que os objetos trabalhados na pesquisa ou na extensão estão de certo modo descolados das disciplinas. Ou seja, são demandas paralelas aos conteúdos ministrados e, em algumas situações, correspondem a uma sequência do tema estudado na pós-graduação 
pelo próprio sujeito, uma espécie de prolongamento de suas temáticas de estudo, dialogando ou não com os conteúdos ministrados nas disciplinas:

- Sim, pesquisa em Representações Sociais em saúde mental em comunidades de baixa renda (ENTREVISTADO 8, 2008, p. 1-8).

- Tem projeto de pesquisa com Parkinson. Pesquisa grande, interinstitucional (ENTREVISTADO 7, 2008, p. 1-15).

- Temos dois: catadores de lixo e violência entre adolescentes. Catadores de lixo a gente vai identificar os riscos trabalhista deles e também os riscos emocionais, então eu estou trabalhando na área de saúde mental com eles [...] (ENTREVISTADO 5, 2009, p. 1-9).

- Estamos trabalhando com atividade de pré-atendimento ao estresse na emergência e em pré-atendimento a nível de SAMU. Então a gente está trabalhando com aluno bolsista do CNPq e a gente está fazendo um trabalho com profissionais de saúde, né? Cuidando do cuidador. A questão dos técnicos no processo de pré-atendimento. Porque toda situação de emergência ela é movimentadora de estresse [...] (ENTREVISTADO 6, 2008, p. 1-10).

Um aspecto importante demonstrado pelas entrevistas é que parte dessas pesquisas e atividades de extensão é financiada pelos órgãos de fomento das instituições, tais como o Conselho Nacional de Desenvolvimento Científico e Tecnológico (CNPq) e a Fundação de Amparo à Pesquisa do Estado da Bahia (Fapesb).

Sabemos que os investimentos destinados à pesquisa em saúde mental, oriundos dos órgãos de 
fomento e diretamente do próprio Governo Federal, vêm crescendo significativamente ${ }^{1}$. Além disso, é crescente também o investimento em programas como o Programa de Educação pelo Trabalho para a Saúde (PET-Saúde) que passou a ser considerado pelo Ministério da Saúde como dispositivo fundamental para fomentar as ações articuladas entre a pesquisa e a extensão nas Instituições de Ensino Superior. Gradativamente, os editais passam a financiar também estudos voltados à problemática do álcool e outras drogas como sendo demanda em saúde mental. Estima-se que o conjunto dos editais, somente oriundos dos órgãos do Governo Federal lançados entre 2008 e 2011, compute mais de $\mathrm{R} \$ 20.000 .000$, o que trará um fôlego financeiro importante para ações centradas no processo de formação de novos profissionais para o campo da saúde mental no Brasil.

\section{Tecnologias de ensino/aprendizagem}

Os recursos adotados como estratégias metodológicas e tecnológicas para garantir o processo ensino-aprendizagem em saúde mental nas práticas pedagógicas dos docentes entrevistados mostraram-se da maior heterogeneidade. Este foi o item observado nas entrevistas com maior diversidade e criatividade. As estratégias variaram desde as aulas mais tradicionais

${ }^{1}$ Edital MCT/CNPq/CT-Saúde/MS/SCTIE/DECIT N. ${ }^{\circ}$ 33/2008; Edital CNPq N. ${ }^{\circ} 41 / 2010$;

Edital No 027/2010/GSIPR/SENAD/MS/MEC 
- tais como as expositivas -, contemplando estratégias como problematização, discussão de caso clínico, oficinas e outras.

Devido à pluralidade dessas estratégias tecnológicas, achamos por bem não organizá-las em categorias para que possamos efetivamente dar conta da riqueza revelada pelas entrevistas. Conforme Pinheiro (1999), a entrevista, enquanto uma produção de sentidos, lida com uma realidade polissêmica; isso traz uma consequência ética para a interpretação de uma pesquisa, compelindo esse processo a não se fechar apenas para o que há de regular nos dados. Desse modo, de acordo com Spink e Medrado (1999, p. 48),

o foco dos estudos que adotam esse conceito deixa de ser, assim, apenas a regularidade, o inviável, o consenso e passa a incluir também a própria variabilidade e polissemia.

Além disso, a diversidade de respostas aqui obtidas está diretamente relacionada à realidade institucional de cada entrevistado, reforçando a tese central do construcionismo social que considera que as práticas discursivas estão diretamente relacionadas à problemática dos contextos de sentido, em que se deve considerar a "cristalização de discursos institucionais, as posições socialmente disponíveis" (SPINK; MEDRADO, 1999, p. 51), entre outros.

Como dito acima, a realidade institucional das universidades estudadas aqui mostrou-se bastante diversificada, a partir dos conteúdos expressados nas entrevistas dos docentes. 
Cenário "a":

Das metodologias tradicionais

- Então, a metodologia mais é leitura de textos direcionados, debate, elaboração de textos em cima desses conhecimentos específicos [...] (ENTREVISTADO 8, 2008, p. 1-8).

- A gente trabalha a parte teórica, conteúdos teóricos, inicialmente, a gente aborda desde a questão dos aspectos históricos da psiquiatria e fala um pouco sobre essa mudança no modelo de tratamento que é a reforma psiquiátrica, aborda os principais transtornos mentais, ações de enfermagem (ENTREVISTADO 4, 2008, p.1-2).

Cenário "b":

Das tecnologias de ensino-aprendizagem que se baseiam na metodologia da problematização.

[...] a gente trabalha muito com a questão da problematização, de estar atuando mesmo como facilitador do processo de aprendizagem, embora também a gente tenha a metodologia que está sendo também construída na verdade [...] (ENTREVISTADO 01, 2008, p. 1-11).

- Habilidade baseada em problemas e, especificamente, no módulo a gente usa, é... Não só as tutorias, né [...] Os tutoriais que é essa habilidade baseada em problema, como também as palestras (ENTREVISTADO 2, 2008, p. 1-10).

- A metodologia aqui é aprendizado baseado em problemas. Então, os problemas do paciente são: a vida dele e dentro desta limitação, é que temos, como alunos de curso de uma faculdade pública, o professores, né? Dentro da nossa realidade, tendo conhecimento da 
limitação do paciente, perceber até aonde o paciente pode ir, nos colocarmos mais de uma forma muito mais enfática de que normativa (ENTREVISTADO 5, 2009, p. 1-9).

No conjunto das respostas que sinalizam a realização do trabalho com base na problematização, verificamos variações interessantes partindo de diferentes modos de compreensão semântica do sentido e do conceito daquilo que vem a ser o questionado:

- A problematização é a comunicação voltada para o processo, onde os alunos estão também construindo conhecimento (ENTREVISTADO 1, 2009, p. 1-11).

- Eu acho que tem que ser a crítica social dos conteúdos, que é um dos tipos de [...] tendências que eu utilizo, onde você tenta passar os conteúdos para os alunos, né? Tudo aquilo que foi produzido não vai ser jogado fora e, a partir daí, você entra com a problematizadora, né? Com a pedagogia mais, mais, mais construtivista, né? Onde o aluno trabalha na produção, na construção do seu conhecimento, onde a gente tem aulas teóricas, né? Dialogadas e temos as práticas do campo (ENTREVISTADO 6, 2008, p. 1-10).

Há práticas que estão em constante processo de recriação, dialogando com diversos recursos e que, por conta desta diversidade, eles não seriam facilmente localizados num único recorte metodológico. Tratase de situações em que se verifica um amplo repertório de maneiras de pensar ou conceber a prática, de modo a permitir o trânsito por diferentes possibilidades de 
ofertas, propostas e estratégias formando um verdadeiro corolário de soluções, dentre elas, destacamos:

a) A dinâmica entre os semestres:

- Em cada semestre que a gente passa, a gente está implementando uma nova forma de, não é nem de transmitir, é de construir, de produzir esse conhecimento [...] (ENTREVISTADO 7, 2008, p. 1-15).

b) A concepção metodológica e a filosofia pedagógica que impactam a práxis:

- A gente trabalha numa linha mais construtivista, numa linha mais problematizadora do que a gente trabalhava antigamente. Então, a nossa metodologia hoje é mais focada no processo de problematização e não naquele ensino, na reprodução, na remastigação do saber (ENTREVISTADO 7, 2008, p. 1-15).

\section{c) A estruturação da disciplina pautada no tripé da universidade:}

- Mas assim, sempre buscando integrar ensino, pesquisa, extensão dentro da disciplina, sempre enfocando a construção do conhecimento não é? De você ensinar a pensar, não é? E não apenas é você transmitir aquilo que a literatura nos mostra, né? Dados da literatura (ENTREVISTADO 7, 2008, p. 1-15).

d) A criação de delineamentos didáticos:

- Então, a gente pegou todas as Portarias referentes à saúde mental, a Lei 10.216, e falou: - Vamos construir uma linha de tempo relacionada com a rede. Então, por exemplo, você pega a portaria que está falando do 
Caps. Então, o aluno na linha de tempo, ele vai localizar essa portaria e ele vai fazer uma articulação com a implementação do serviço. Então, a gente fez a construção desse painel integrado, desse que a gente chamou de linha de tempo, com todas as portarias e também associando as Residências Terapêuticas, o Ambulatório, o Hospital Geral (ENTREVISTADO 7, 2008, p. 1-15).

e) $\mathrm{O}$ desenvolvimento de habilidades como o controle social:

- Então, o objetivo nosso era que o aluno quando fosse apresentar isso em sala de aula e a gente está levando isso para fora dos muros da universidade. Isso que a gente construiu aqui, ele vai reproduzir isso lá fora. A gente pensou em marcar um dia na câmara de vereadores, um dia quem sabe, convidar os vereadores e a comunidade em geral, onde a gente pudesse estar debatendo esses conteúdos, lá. Então a gente trabalhou com esses seminários que a gente chamou linha de tempo, de painel integrado e tal. Num outro momento, a gente trabalhou com júri simulado, a questão da reforma psiquiátrica, discutindo a psiquiatria e a saúde mental (ENTREVISTADO 7, 2008, p. 1-15).

\section{f) O uso de outros atores e outros discursos como interlocutores:}

- Conseguimos até trazer um promotor público para a sala de aula (ENTREVISTADO 7, 2008, p. 1-15)

g) O uso de recursos que desenvolvam habilidades específicas: 
- Trabalhou a comunicação, trabalha com exposição dialogada também e com textos, essa parte de comunicação e relacionamento em que a gente trabalhou a comunicação como um processo e não aquela comunicação linear [...] Emissor, receptor (ENTREVISTADO 7, 2008, p. 1-15).

h) A utilização de recursos ou metodologia ativa como a intervenção em campo:

- A gente vai, os professores, né? Os professores vão lá com o agente comunitário, visitam a casa do usuário, da família. Leva o aluno, apresenta o aluno e aí o aluno desenvolve duas visitas, ou três, quantas forem necessárias para ajudar essa família a compreender e fazer alguma sorte de intervenção junto a família (ENTREVISTADO 7, 2008, p. 1-15).

A riqueza de relatos como esses mostra a vivacidade, a dinamicidade, a versatilidade e o caráter multifacetado da práxis pedagógica, além de considerar a complexidade que caracteriza o campo da saúde mental. Vê-se, aqui, a combinação entre um objeto que exige ser abordado de modo multilateral e a disposição e utilização de um verdadeiro arsenal de recursos para a sua devida apropriação.

\section{Práticas discursivas sobre saúde mental e re- forma psiquiátrica}

De modo semelhante ao que caracterizou o tópico anterior, as respostas obtidas aqui variaram bastante. $\mathrm{O}$ olhar dos entrevistados sobre a função 
exercida pela universidade no processo de reforma psiquiátrica mostrou-se, invariavelmente, polissêmico. Os discursos manifestados pelos entrevistados revelam a gênese e as circunstâncias do processo e a reforma da atenção psiquiátrica em si, bem como evidenciam aspectos da própria inserção das universidades que atuam no campo das políticas públicas.

Como defende Bezerra Júnior (1992), em se tratando da perspectiva histórica e semântica da reforma da atenção psiquiátrica pode-se considerar que sua trajetória não é linear; a compreensão por parte dos atores e das forças que a compõe não é homogênea e sua organicidade, enquanto movimento, não tem sido constante. Spink e Medrado (1999) afirmam que a compreensão dos sentidos do discurso exige atenção ao tempo vivido, ou seja, ao processo de ressignificação dos conteúdos a partir de processos de socialização em que a produção do sentido tem como foco o contexto em que é produzido.

Sabemos que o processo de reforma da atenção psiquiátrica na Bahia é retardatário, quando comparado com o mesmo movimento em outros contextos do Brasil ${ }^{2}$. Além disso, as experiências locais são demasiadamente díspares, com contextos e cenários bastante avançados, porém, aquém das realidades

${ }^{2}$ Ver o Relatório de Gestão 2007-2010 publicado pelo Ministério da Saúde, em 2011. Os Caps, na Bahia, só começam a ser implantados em 2002. Com mais afinco, somente na segunda metade da década o número de serviço consegue uma ampliação razoável, mas ainda abaixo do preconizado pelas metas do próprio Ministério (N. A.). 
que dizem respeito aos resultados da reforma da atenção psiquiátrica. Isso caracteriza a falta de linearidade e de homogeneidade do processo da reforma na Bahia. Vê-se tal panorama revelado nos discursos dos entrevistados. Há de se considerar, ainda, a diversidade de projetos pedagógicos nas universidades baianas nos quais é possível encontrar desde cursos com disciplinas fragmentadas até cursos com desenho metodológico modular. No geral, há consenso no sentido de conceber a universidade como um dispositivo importante no processo de reforma da atenção psiquiátrica.

Diante da diversidade de pontos de vista, organizamos os conteúdos emergentes dos entrevistados sobre o tópico em dois eixos: as contribuições da universidade para a reforma psiquiátrica e os sentidos da reforma psiquiátrica.

As contribuições da universidade para a reforma psiquiátrica

Na resposta a seguir, vê-se a consideração do compromisso social da universidade centrado no processo de formação de profissionais:

- A universidade, ela tem um compromisso social, que é a formação de profissionais que vão se inserir no mercado de trabalho. Se a universidade, ela não prepara com qualidade, né? [...]

- Esses futuros profissionais, quem é que vai preparar? Então, o que, que na verdade está sendo mais necessário? [...] 
-Acho que a universidade vai ser a incubadora para isso [...]

- É a função da universidade (ENTREVISTADO 3, 2008, p. 1-5).

Verificamos enunciados que atribuem a contribuição da universidade para o processo de reforma da atenção psiquiátrica centrado apenas na mudança dos conteúdos ministrados, dando a entender que isso, por si mesmo, poderia produzir o efeito de transformação das práticas:

- Eu acho que nós já estamos nesse processo de contribuir, quando a gente está discutindo a grade, readequando disciplinas e voltando muito para isso, por que veja: eles estão no começo do curso deles ainda, há todo um caminho a percorrer que, se a grade for voltada pra essa idéia de cuidar do ser humano com uma totalidade, eles vão sair profissionais com essa mentalidade. Então, mais do que ninguém, nós somos responsáveis por isso (ENTREVISTADO 3, 2008, p. 1-5).

No enunciado que se segue, nota-se um aspecto bastante particular; por um lado, o sujeito compreende a importância da universidade no processo da reforma, por outro, faz uma leitura crítica, tomando por base as dificuldades e a sobrecarga do trabalho docente, o que em parte obstaculizam uma contribuição maior. É interessante ver que isso não lhe impede de afirmar a importância da universidade nesse processo, considerando-a uma condição. 
- Acho que pode contribuir muito, mas só de pensar em contribuir eu me canso. Porque, assim, nós estamos num momento muito crítico da docência no estado, acho que deva ser uma aliança necessária, quase que devia ser até uma condição, uma condição, essa articulação da universidade (ENTREVISTADO 2, 2008, p.1-10).

Os sentidos da reforma psiquiátrica

Considerando que a reforma da atenção psiquiátrica se fundamenta numa construção social, os sentidos e significados atribuídos a esse processo acabam sendo a base da práxis, ou seja, balizam o modo como o sujeito age no campo da saúde mental.

Num estudo realizado por Nunes et al. (2008), detectou-se um conflito ou uma dispersão no que diz respeito aos significados atribuídos ao campo das práticas em saúde mental por atores das atividades fins nos serviços. Detectou-se a coexistência de, ao menos, três grandes modelos ou discursos: o centrado no modelo biomédico humanizado; o psicossocial com ênfase na instituição e, por fim, o discurso psicossocial com ênfase no território.

Pode-se observar, também, a existência de uma diversidade de sentidos no que diz respeito à avaliação da reforma da atenção psiquiátrica. Identificou-se certa convergência no sentido de que a reforma é necessária, inevitável, mas também que é fundamental avançar ainda mais para que efetivamente se consolide.

Apenas um docente, embora lecione disciplinas voltadas para o campo da saúde mental, referiu não 
conhecer a reforma psiquiátrica: - Olha, estou por fora. Então eu não posso falar nada, sinceramente (ENTREVISTADO 3, 2008, p. 1-5).

As demais entrevistas revelam docentes com uma clara e profunda compreensão do processo da reforma da atenção psiquiátrica em todos os sentidos, no que diz respeito ao cenário político, ideológico, clínico e organizacional. Interessante notar que, mesmo havendo concordância com a reforma, a maioria dos entrevistados consegue fazer uma leitura crítica dos avanços e das inconsistências da política de saúde mental no Brasil.

Sobre os novos dispositivos do campo da saúde mental, a avaliação construída pelos docentes considera até mesmo uma possível estagnação na continuidade de determinados fundamentos da reforma. Trata-se de uma "perspectiva crítica", com ponderações ao modelo de rede e de dispositivos concebido para a sustentação desse processo:

- A reforma psiquiátrica, eu vejo assim, que, enquanto projeto, ele é maravilhoso, mas está faltando alguns trabalhos a serem realizados né [...] Por exemplo: qual a função do NAPS e do Caps né [...] O que nós vamos fazer com os pacientes moradores (de rua)? Tudo bem [...] Nós temos os lares abrigados né [...] E a questão do hospital guia como é que fica, né [...] E a questão do paciente que ocupa leito psiquiátrico no hospital geral mas, se nós não temos uma saúde pública de qualidade, como é que essa equipe está preparada para atender o paciente psiquiátrico nessa instituição geral se ele ainda não está preparado para atender direito com qualidade o serviço? A 
reforma psiquiátrica para mim, ela tem um ponto muito positivo, quando ela trabalha o resgate da identidade do sujeito, mas ela se perdeu quando ela não soube dar a sua continuidade [...] ENTREVISTADO 8, 2008, p. 1-8).

O discurso seguinte apropria-se de um aspecto do conceito da reforma tecendo relações entre os aspectos constitutivos e as apostas no que diz respeito aos fundamentos da reforma psiquiátrica. Poderíamos identificar essas respostas como sendo caracterizadas pela preocupação com uma "perspectiva ideológico-política” da reforma. É o que se observa a seguir:

- Eu vejo que, de fato [...] reforma psiquiátrica mesmo, por que há trabalho acontecendo dentro dos hospitais, dentro da psiquiatria. Algumas reformas mesmo, no sentido de melhorar o atendimento dos usuários da psiquiatria, vamos dizer. Mas, o que eu entendo desse movimento e o que eu acredito é que é muito mais do que uma reforma, ele tem o nome de reforma, mas na verdade, é uma mudança mesmo, uma transformação. Pelo menos eu não acredito mais que dê para reformar a psiquiatria. Eu acredito que tem que se transformar a psiquiatria em saúde mental e isso, é claro, que a gente tem que aproveitar todas as contribuições. Até Pinel fez uma reforma psiquiátrica e a gente precisa também aproveitar tudo que foi construído da nossa história [...] Aproveitar o passado para estar construindo o presente, o futuro. Não é deixar o caminho [...] Então a nossa proposta nesse modelo, nessa nova perspectiva de trabalhar 
a saúde mental é trabalhar o sujeito, colocar a doença entre parênteses e trabalhar o sujeito [...] (ENTREVISTADO 1, 2008, p.1-11)

Entre os entrevistados, também foi evidenciada uma "perspectiva cidadã", visando à inserção social. Esta se volta para a relação entre a compreensão do sujeito portador de transtorno mental e as questões da cidadania:

- Olha, eu acho que a gente não tem nem o que discutir [...] Então, eu acho que a reforma psiquiátrica é a solução para o avanço da compreensão da pessoa com transtorno mental e no tratamento também, porque ela é quem está dando essa possibilidade de ver a pessoa com transtorno mental como cidadão, como cidadã e que deve estar inserida na sociedade e que deve se tratada como pessoa humana, inserida na sociedade (ENTREVISTADO 7, 2008, p. 1-15).

Concepções sobre saúde mental na Estratégia de Saúde da Família

Este tópico corresponde ao principal motivo deste estudo - a investigação sobre o processo de ensino-aprendizagem em saúde mental com foco na Estratégia de Saúde da Família (ESF). Trata-se de uma discussão capital, hoje, no cenário das políticas públicas em saúde mental, a grande meta da reinserção social só acontece efetivamente no território onde o sujeito vive o seu cotidiano. Não há dúvidas de que serviços especializados como os Caps são importantes nesse 
processo, mas há de se considerar que acabam produzindo certa "desterritorialização", visto que o sujeito precisa sair do seu habitat cotidiano (familiar, social, cultural e outros) para dirigir-se a um serviço que, na maioria das vezes, está fora do seu bairro.

Desde a reforma psiquiátrica italiana, já há toda uma discussão acumulada, considerada resolutiva e impactante, no sentido de intensificar as estratégias que garantam a atenção no território. No que concerne ao processo de reorientação das políticas públicas em saúde mental no Brasil, Lima Junior (2010, p. 230) afirma que

o ideal da reinserção psicossocial, um dos motores da Reforma Psiquiátrica brasileira, pressupõe que a reinserção se dará na comunidade da qual o sujeito faz parte. É lá, portanto, que deve ocorrer a radicalidade das ações de saúde mental, pautadas nos princípios da Reforma Psiquiátrica.

Para a incorporação, ampliação e consolidação de qualquer diretriz política, há a necessidade de encontrar respaldo e adesão no conjunto dos atores que serão responsáveis pela execução do processo. Em se tratando da incorporação da saúde mental na atenção básica, parece haver um conjunto de obstáculos que dificultam essa relação. Segundo Campos e Gama (2008, p. 223),

a falta de diretrizes, a falta de preparo técnico do profissional... fazem com que a demanda de saúde mental não encontre uma escuta qualificada e muitas vezes tratada apenas com medicação. 
Diante dessa constatação, torna-se necessária e urgente uma política de formação de profissionais para a ESF com competências e habilidades também em saúde mental, a fim de que a própria reforma da atenção psiquiátrica avance, uma vez que esse nível de complexidade do sistema tem a capilaridade necessária para a reinserção psicossocial tão desejada pelo movimento.

Os fragmentos descritos a seguir apresentam o que pensam os docentes responsáveis pela formação de novos profissionais no estado da Bahia. Saber sobre como pensam e quais os sentidos atribuídos tanto a sua práxis quanto à viabilidade dessa interlocução é imprescindível para o delineamento de uma futura diretriz política concernente à formação profissional. De modo unânime, todos os entrevistados acreditam ser fundamental a inserção da saúde mental na ESF.

No trecho descrito a seguir, de um entrevistado, a compreensão do que seja a saúde mental é genérica, sem referência ao atual paradigma; tem como pressuposto da reforma da atenção psiquiátrica a importância da saúde mental na atenção básica, isso para que não haja uma dicotomização entre a mente e o físico. Quando questionado sobre a reforma da atenção psiquiátrica, o entrevistado respondeu o seguinte:

- Eu acredito que seja uma coisa importante [...]. A gente ainda tem um modelo no Brasil que trabalha só com a questão da saúde física, não é? A gente vai num médico, ele não quer [saber] qual é o seu estado mental, ele só trata o seu corpo (ENTREVISTADO 3, 2008, p. 1-5). 
$\mathrm{Na}$ interlocução entre as saúdes mental e familiar existem alguns gargalos no que diz respeito ao acolhimento. Embora ainda pouco expressivos numericamente, existem estudos sinalizando a existência de demanda reprimida de atenção à saúde mental na atenção básica (DIMENSTEIN et al., 2005). Essa constatação pode ser ainda mais evidente quando se trata de necessidades de cuidados em clínica médica geral, demandados por portador de transtorno mental que, frequentemente, tem seu objetivo reprimido, mesmo que o motivo não seja a atenção especializada. Essa foi a interpretação do entrevistado, como descrito abaixo:

- A inserção do doente mental no PSF é por que o sujeito, ele tem que ver que ele tem direito de usar o serviço de saúde. Esse serviço de saúde não necessariamente tem que ser geral ou mental, é serviço de saúde. E se o PSF é um serviço de saúde público, ele não é um serviço de saúde especializado. Ele é um serviço de saúde generalizado, que a doença mental está implicada aí dentro. E eu sou a favor que ele use o PSF (ENTREVISTADO 8, 2008, p. 1-8).

Uma das possibilidades de se compreender a relação entre saúde mental e saúde da família parte da conjectura de que a atenção básica tem que ser a "porta de entrada" de toda a população, independente da demanda ou necessidade de saúde apresentada. Em geral, a procura por cuidados em saúde mental leva diretamente aos serviços ditos especializados, criando um descompasso entre a lógica da hierarquização e os 
níveis de complexidade da atenção. No discurso descrito abaixo há a compreensão de que a saúde mental também compõe o campo da saúde coletiva.

- E vejo que é essencial. Porque, assim como a saúde mental está totalmente dentro da saúde coletiva [...] Então, as pessoas estão ali no território de abrangência das unidades de saúde da família [...] Então, eu vejo que a porta de entrada, como qualquer outro sujeito, e a pessoa em sofrimento mental, que é diferente, e muitas vezes ele entra por outras necessidades de saúde, não por causa do seu sofrimento mental. Ele pode estar muito bem com a sua saúde mental e ter acesso a esses serviços (ENTREVISTADO 01, 2008, p. 1-11).

Embora concordante com o fato de que a saúde mental deve ter como porta de entrada a atenção básica, o trecho a seguir aponta um aspecto problemático dessa relação, qual seja: a pouca assimilação do discurso da saúde mental por parte dos profissionais da ESF:

- Eu acho que a atenção básica ainda não assimilou. Fora o serviço de saúde mental, que também tem a ver com a atenção básica, mas eu estou falando assim [...] Das unidades de PSF e os centros de saúde [...] Ainda não assimilou [...] Não assimilou, é [...] Ainda não incorporou a idéia, a noção de que a pessoa com transtorno mental tem que ser cuidada como a outra pessoa [...] mas eu acho fundamental, para mim é a porta [...] É o primeiro contato da família, primeiro a quem ele deve se dirigir, porque ele está inserido numa área [...] (ENTREVISTADO 7, 2008, p. 1-15). 
A entrada da saúde mental na ESF pode trazer ganhos para a própria equipe de saúde, isso é o que se verifica no discurso abaixo. Destaque-se o fato de que o entrevistado ressalta que a saúde mental não pode ser confundida com a intervenção especializada dos profissionais do campo "psi", ao invés disso deve haver uma série de "possibilidades de intervenção":

- Então, eu acho que a saúde mental na atenção básica tem esse papel, de ter um olhar para a equipe e para saúde mental da equipe, ou para municiar essa equipe de técnicas, de conhecimentos e de informação para lidar com o portador de saúde mental dentro da comunidade [...] Borbulha na minha cabeça milhões de possibilidades de intervenção e que nem uma delas seria a psicoterapia, por exemplo, entendeu? (ENTREVISTADO 2, 2008, p. 1-10)

A ampliação da demanda de trabalho foi apontada como um aspecto relevante para a incorporação da saúde mental na ESF. Embora inevitável, esse processo pode encontrar resistência se trouxer impacto e desgaste para os profissionais da atenção básica. De acordo com o discurso apresentado abaixo, a equipe da ESF seria incumbida de acolher a demanda dos transtornos leves e moderados, uma demanda epidemiologicamente bastante expressiva. Contudo, é o grande dispositivo preconizado pela reforma da atenção psiquiátrica, a reinserção psicossocial, baseada na construção de vínculos sociais solidários. Pode-se afirmar que a ESF é, de longe, o mais significativo dispositivo da rede, pois que pode tornar possível essa meta: 
- Eu acho que o PSF, eu estou até com pena da equipe da saúde da família, porque tudo termina caindo nas costas deles. Porque a proposta é um novo modelo, uma reorientação. Que nós sabemos que temos níveis de transtorno mental leve e moderado e a tendência nossa só especializar o que o profissional na área geral não dá conta. Então a princípio eu acho que o profissional da área de saúde da atenção básica pode ser qualificado, pode fazer o acolhimento e o encaminhamento do paciente mesmo porque se nós pensarmos uma boa equipe de saúde da família na sua atuação que sendo o profissional e a própria unidade ela é facilitadora dos vínculos sociais (ENTREVISTADO 05, 2009, p. 1-9).

\section{Considerações finais}

Longe da pretensão de oferecer uma visão última, imponderável ou inconteste, as conclusões aqui devem considerar um conjunto de situações. A realidade das políticas de saúde mental na Bahia deve ser considerada a partir da sua singularidade. $\mathrm{O}$ momento de início, o ritmo, a dinâmica, os resultados e o impacto da reforma da atenção psiquiátrica na Bahia possuem nuances que a torna diferente do modo como o processo tem acontecido em outros contextos do território brasileiro. Certamente, este cenário influencia muito o modo pelo qual os sujeitos entrevistados construíram suas respostas. Ademais, como o tema ainda é pouco investigado, estudos como esses são uma espécie de locomotiva; como tudo aquilo que se arrisca a criar campos de discursividade, está 
sujeito a fragilidades. Contudo, nada disso diminui o mérito dos achados apresentados aqui. Os registros colhidos apresentam um importante retrato da realidade da formação para o campo da saúde mental na Bahia, oferecendo uma perspectiva panorâmica desse cenário.

Em linhas gerais, fica a impressão de que estamos lidando com um objeto demasiadamente heterogêneo, por isso rico de experiências que em determinados momentos se complementam, mas que, em algumas situações, conflitam sutilmente. Disso decorre a importância e a singularidade da experiência baiana. Fica, ainda, a impressão de que esse parece ser um processo vivo, em ebulição, tenso como tem de ser todo movimento de mudança, dinâmico como precisa ser tudo aquilo que pretender fazer história.

Do percurso apresentado nesse capítulo se pode constatar:

-A necessidade de criação de dispositivos que possam permitir uma maior interlocução entre as instituições (de ensino e de serviço) com o propósito de facilitar a troca de experiências;

-A garantia da singularidade da experiência de ensino/aprendizagem em saúde mental como uma construção social diversa e polissêmica, criando metas comuns para isso;

- Não recuar diante dos obstáculos enfrentados na produção de diálogos entre, saúde mental e a atenção básica. 


\section{Referências}

BEZERRA JÚNIOR, B. De médico, de louco e de todo mundo um pouco. O campo psiquiátrico no Brasil nos anos oitenta. In: GUIMARÃES, R.; TAVARES, R. (org.) Saúde e sociedade no Brasil: anos 80. Rio de Janeiro: Relume Dumará: Editora da UFRJ, 1992.

BRASIL. Ministério da Educação. Secretaria de Educação Superior. CNE/CES. Resolução N.o 3, de 7 de novembro de 2001. Institui Diretrizes Curriculares Nacionais do Curso de Graduação em Enfermagem. Brasília, DF: MEC, [200-]. Disponível em: < http://portal.mec.gov. $\mathrm{br} / \mathrm{cne}$ /arquivos/pdf/CESo3.pdf > . Acesso em: 2 out. 2013 .

BRASIL. Ministério da Educação. Secretaria de Educação Superior. CNE/CES. Resolução N.o 8, de 7 de maio de 2004. Institui as Diretrizes Curriculares Nacionais para os cursos de graduação em Psicologia. Brasília, DF: MEC, [200-]. Disponível em: <http://portal.mec. gov.br/cne/arquivos/pdf/rceso8_04.pdf>. Acesso em: 2 out. 2013.

- Ministério da Saúde. Secretaria de Atenção à Saúde/DAPE. Coordenação Geral de Saúde Mental. Reforma psiquiátrica e política de saúde mental no Brasil. Documento apresentado à Conferência Regional de Reforma dos Serviços de Saúde Mental: 15 anos depois de Caracas. Brasília, DF: OPAS, 2005. Disponível em: <http://bvsms.saude.gov.br/bvs/publicacoes/relatorio15_anos_caracas.pdf>. Acesso em: 2 out. 2013.

BRASIL. Ministério da Saúde. Secretaria de Atenção à Saúde/DAPE. Coordenação Geral de Saúde Mental, Álcool e Outras Drogas. Saúde mental no SUS. As novas 
fronteiras da Reforma Psiquiátrica. Relatório de Gestão 2007-2010. Brasília, DF, 2011.106p. Disponível em: $<$ http://portal.saude.gov.br/portal/arquivos/pdf/gesta02007_2010.pdf>. Acesso em: 2 out. 2013.

CAMPOS, R. O.; GAMA, C. A. P. Saúde mental na Atenção Básica. In: CAMPOS, G. W. S.; GUERREIRO, A. V. P. (org). Manual de Práticas de Atenção Básica: saúde ampliada e compartilhada. São Paulo: Hucitec, 2008.

CECCIM, R. B.; FEUERWERKE, L. C. M. O quadrilátero da formação para a área da saúde: ensino, gestão, atenção e controle social. Physis. Revista de Saúde Coletiva, Rio de Janeiro, v. 14, n.1, p. 1, jan./jun. 2004. Disponível em: < http://www.scielo.br/scielo.php?script=sci_issuetoc\&pid $=0103-733120040001 \& \operatorname{lng}=\mathrm{pt} \& \mathrm{nrm}=$ iso $>$. Acesso em: 2 out. 2013.

DIMENSTEIN, M. et al. Demanda em saúde mental em unidade de saúde da família. Mental, Barbacena, v. 3, n. 5, p. 23-41, 2005.

\section{ENTREVISTADO 1. Projeto Construção Social da} Aprendizagem acerca da Saúde Mental e Saúde da Família: entrevista [abr. 2008]. Entrevistadora: Erika Antunes Vasconcellos. Ilhéus: Uesc; Fapesb, 2009, gravador digital. p. 1-11. Entrevista concedida ao Projeto Construção Social da Aprendizagem acerca da Saúde Mental e Saúde da Família.

\section{ENTREVISTADO 2. Projeto Construção Social da} Aprendizagem acerca da Saúde Mental e Saúde da Família: entrevista [abr. 2008]. Entrevistadora: Erika Antunes Vasconcellos. Ilhéus: Uesc; Fapesb, 2009, gravador digital. p. 1-10. Entrevista concedida ao Projeto Construção Social da Aprendizagem acerca da Saúde Mental e Saúde da Família. 
ENTREVISTADO 3. Projeto Construção Social da Aprendizagem acerca da Saúde Mental e Saúde da Família: entrevista [abr. 2008]. Entrevistadora: Erika Antunes Vasconcellos. Ilhéus: Uesc; Fapesb, 2009, gravador digital. p. 1-5. Entrevista concedida ao Projeto Construção Social da Aprendizagem acerca da Saúde Mental e Saúde da Família.

\section{ENTREVISTADO 4. Projeto Construção Social da} Aprendizagem acerca da Saúde Mental e Saúde da Família: entrevista [mar. 2008]. Entrevistadora: Erika Antunes Vasconcellos. Ilhéus: Uesc; Fapesb, 2009, gravador digital. p.1-4. Entrevista concedida ao Projeto Construção Social da Aprendizagem acerca da Saúde Mental e Saúde da Família.

\section{ENTREVISTADO 5. Projeto Construção Social da} Aprendizagem acerca da Saúde Mental e Saúde da Família: entrevista [fev. 2008]. Entrevistadora: Erika Antunes Vasconcellos. Ilhéus: Uesc; Fapesb, 2009, gravador digital. p. 1-9. Entrevista concedida ao Projeto Construção Social da Aprendizagem acerca da Saúde Mental e Saúde da Família.

\section{ENTREVISTADO 6. Projeto Construção Social da} Aprendizagem acerca da Saúde Mental e Saúde da Família: entrevista [jun. 2008]. Entrevistadora: Erika Antunes Vasconcellos. Ilhéus: Uesc; Fapesb, 2009, gravador digital. p. 1-10. Entrevista concedida ao Projeto Construção Social da Aprendizagem acerca da Saúde Mental e Saúde da Família.

\section{ENTREVISTADO 7. Projeto Construção Social da} Aprendizagem acerca da Saúde Mental e Saúde da Família: entrevista [abr. 2008]. Entrevistadora: Erika Antunes Vasconcellos. Ilhéus: Uesc; Fapesb, 2009, gravador digital. p. 1-15. Entrevista concedida ao Projeto Construção Social da Aprendizagem acerca da Saúde Mental e Saúde da Família. 
ENTREVISTADO 8. Projeto Construção Social da Aprendizagem acerca da Saúde Mental e Saúde da Família: entrevista [abr. 2008]. Entrevistadora: Erika Antunes Vasconcellos. Ilhéus: Uesc; Fapesb, 2009, gravador digital. p. 1-8. Entrevista concedida ao Projeto Construção Social da Aprendizagem acerca da Saúde Mental e Saúde da Família.

ENTREVISTADO 9. Projeto Construção Social da Aprendizagem acerca da Saúde Mental e Saúde da Família: entrevista [jun. 2008]. Entrevistadora: Erika Antunes Vasconcellos. Ilhéus: Uesc; Fapesb, 2009, gravador digital. p. 1-4. Entrevista concedida ao Projeto Construção Social da Aprendizagem acerca da Saúde Mental e Saúde da Família.

\section{ENTREVISTADO 10. Projeto Construção Social da} Aprendizagem acerca da Saúde Mental e Saúde da Família: entrevista [jul. 2008]. Entrevistadora: Erika Antunes Vasconcellos. Ilhéus: Uesc; Fapesb, 2009, gravador digital. p.1-11. Entrevista concedida ao Projeto Construção Social da Aprendizagem acerca da Saúde Mental e Saúde da Família.

FURTADO, J. P. Avaliação de programas e serviços. In: CAMPOS, G. W. S. et al. Tratado de Saúde Coletiva. São Paulo: Hucitec; Rio de Janeiro: Ed. Fiocruz, 2006.

KRAUSZ, R.R. Algumas reflexões sobre a formação de recursos humanos para a saúde pública. Revista de Saúde Pública, São Paulo, v. 11, n. 1, p.151-155, mar. 1997.

LIMA JÚNIOR, J. M.; MELO, S. C. F.; BRAGA, L. A. V.; DIAS, M. D. Saúde mental e saúde da família: implicações, limites e possibilidades. Cadernos de Saúde

Coletiva, v. 18, n. 2, p. 229-233, abr./jun. 2010. 
LOBOSQUE, A. M. Um desafio à formação: nem a perda da teoria, nem o medo da invenção. In: . (org.).

Caderno Saúde Mental, Belo Horizonte, v. 1, p. 33-44, 2007.

LUCCHESE, R. A enfermagem psiquiátrica e saúde mental: a necessária constituição de competências na formação e na prática do enfermeiro. Revista Eletrônica de Enfermagem, Goiânia, v. 9, n. 3, p. 883-885, 2007. Disponível em <http://www.fen.ufg.br/revista/v9/n3/ v9n3a28.htm>. Acesso em: 14 nov. 2012.

NUNES, M. et al. A dinâmica do cuidado em saúde mental: signos, significados e práticas de profissionais em um Centro de Assistência Psicossocial em Salvador, Bahia, Brasil. Cadernos Saúde Pública, Rio de Janeiro, v. 24, n. 1, p. 188-196, jan. 2008.

OLIVEIRA, A. G. B.; ALESSI, N. P. O trabalho de enfermagem em saúde mental: contradições e potencialidades atuais. Revista Latino-Americana de Enfermagem, Ribeirão Preto, v. 11, n. 3, p. 333-340, maio/jun. 2003.

PINHEIRO, O. G. Entrevista: uma prática discursiva. In: SPINK, M. J. (org). Práticas discursivas e produção de sentido no cotidiano: aproximações teóricas e metodológicas. São Paulo: Cortez Editora, 1999.

SANTOS, B. S. A universidade do século XXI: para uma reforma democrática e emancipatória da Universidade. São Paulo: Cortez Editora, 2005.

SOUZA, A. J. F. MATIAS, G. N.; GOMES, K. F. A. A saúde mental no Programa de Saúde da Família. Revista Brasileira de Enfermagem, Brasília, DF, v. 6o, n. 4, p. 391-395, jul./ago. 2007. 
SPINK, M. J. Psicologia Social e saúde: práticas, saberes e sentidos. Petrópolis: Editora Vozes, 2003.

SPINK, M. J.; MEDRADO, B. Produção de sentidos no cotidiano: uma abordagem teórico-metodológica para análise das práticas discursivas. In: SPINK, M. J. (org). Práticas discursivas e produção de sentido no cotidiano: aproximações teóricas e metodológicas. São Paulo: Cortez Editora, 1999. 

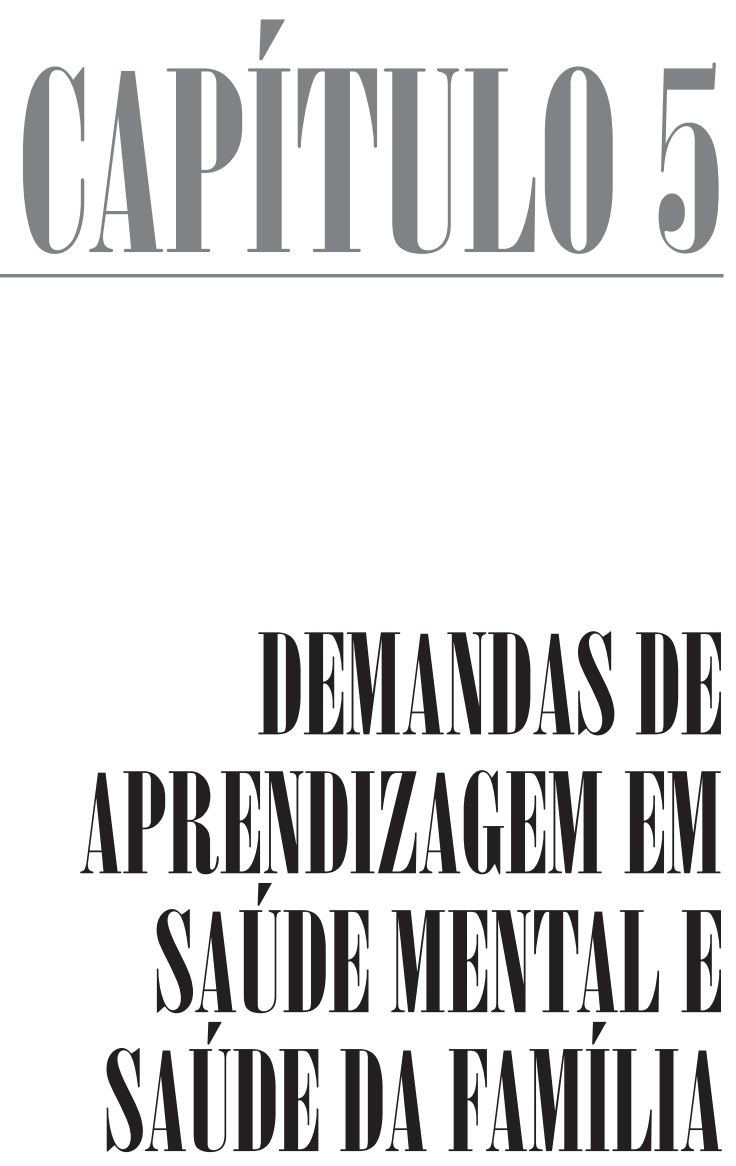

Georoge Amirlial Sintos Rozemere Cirrdoso de Souza 


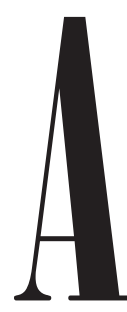

Estratégia de Saúde da Família (ESF) traz consigo o estímulo à atenção de base territorial e comunitária a partir dos encontros e vínculos com a população, da inserção da comunidade na equipe profissional e do foco na família (SOUZA, 2004). Também busca atender, de forma efetiva, a grande variedade de demandas que se apresentam no cotidiano, tendo em vista a máxima resolutividade possível.

Nesse caminhar, as equipes da ESF devem estar familiarizadas aos condicionantes de saúde do território e aptas a articular múltiplos conhecimentos na identificação de riscos e vulnerabilidade de grupos, famílias e indivíduos, essas condições são importantes para a criação de projetos terapêuticos singulares e resolutivos (CAMPOS, 2007).

Isto é de grande importância para a reforma da atenção psiquiátrica, na medida em que, potencialmente, busca a (res) significação da pessoa e da família que convive com transtornos mentais e a sua habitação nos espaços da comunidade, tendo suas demandas atendidas. Dessa forma, podem-se desenhar caminhos de integralidade na produção do cuidado, cujo objeto passa a ser "não mais a periculosidade e a doença, mas a existência-sofrimento dos pacientes e sua relação com o corpo social" (ROTELLI, 1990, p. 30).

Atrelado a isto, pode-se pensar que as demandas por aprendizagem em saúde mental também dizem respeito ao fato de que muitos profissionais tiveram, em sua formação, contato quase exclusivo com o hospital psiquiátrico e suas mazelas, um lugar de exclusão social e anulação de subjetividades e cidadania. Para 
além desse espaço, pouco se sabe sobre como cuidar das pessoas em sofrimento mental grave, de modo que a inversão desse modelo e a invenção de novas práticas - objetivos do processo de Reforma da Atenção Psiquiátrica - requerem transformações na formação acadêmica e profissional desses trabalhadores (NUNES; JUCÁ; VALENTIM, 2007; NASCIMENTO; BRAGA, 2004; SILVA, 2010).

O processo educativo é, pois, fundamental para a construção da reforma e deve contemplar necessidades e recursos locais a seu favor. Pode-se pensar, então, que dentro do cotidiano de trabalho, quando surge a indagação: “O que fazer?” pode-se ler em concomitância: "O que saber?”.

A partir da pesquisa com equipes de saúde da família no estado da Bahia, questionamos sobre quais demandas por aprendizagem em saúde mental surgem no cotidiano de sua atuação e quais as estratégias e tecnologias de produção pedagógica são esperadas por elas para a construção do conhecimento.

Assim, passamos a descrever necessidades e demandas de aprendizagem em saúde mental produzidas nos grupos focais realizados com equipes da ESF de cinco municípios do estado da Bahia.

Agruparam-se os repertórios interpretativos dos conteúdos emergentes nos grupos que davam sentido(s) às demandas por aprendizagem em saúde mental na ESF, a partir de categorias que refletiram os problemas do cotidiano. São elas:

- Aprender sobre medicações psicotrópicas, devido à necessidade de orientar a clientela 
quanto à prescrição ou ao seu uso na Unidade de Saúde da Família.

- Conhecer para intervir sobre o processo saúde/ doença mental, ao considerar a necessidade de identificar um sujeito em sofrimento psíquico e de saber sobre os fatores desencadeantes do adoecimento mental e quais as formas de tratamento e prevenção.

- Agir sem preconceito, ao considerar a necessidade de trabalhar o medo frente à pessoa com transtorno mental.

- Desenvolver tecnologias de "aproximação" como resultados da necessidade de conhecer e de se responsabilizar pelo usuário que sofre mentalmente.

- Atuar como facilitadores da inclusão social, ao considerar a necessidade de saber como contribuir para a efetivação desse processo em saúde mental.

- Desenvolver habilidades de manejo frente ao usuário de álcool e outras drogas, por ser uma problemática marcadamente presente no cotidiano do trabalho das equipes.

- Desenvolver habilidades de apoio às famílias que vivenciam o adoecimento mental, por considerar a necessidade de contribuir com a produção de cuidado desenvolvido neste grupo, tanto mediado quanto carente da atenção à saúde.

- Receber cuidados que promovam a saúde mental e o bem-estar, desenvolvendo o autocuidado para cuidar de outros, ao referirem à necessidade de se autoconhecerem e de serem 
atendidas em suas próprias necessidades de saúde mental.

\section{Aprender sobre medicações psicotrópicas}

Esse aprendizado advém do desejo das equipes em saber como atender a demanda imediata do paciente no que se refere à medicação, seja o ato de prescrevê-la ou de orientar quanto ao seu uso. Há uma dificuldade dos clínicos que atuam nas Unidades de Saúde da Família para identificar e tratar adequadamente transtornos mentais comuns, como os caracterizados por um conjunto de sintomas que se associam à depressão e a ansiedade. Na literatura, essa situação é explicitada por dois aspectos: o estigma que envolve os transtornos mentais e os locais de aprendizagem durante a formação destes profissionais terem sido muito distantes da realidade do seu cotidiano (VALENTINI, 2004; RIBEIRO, 2007).

Diante da limitação desse aprendizado, pode-se identificar, no fragmento a seguir, um exemplo do que é feito e aprendido no cotidiano:

- Medicamentos [...] eu só prescrevo depois que o paciente passou pelo psiquiatra. Eu não prescrevo nenhum medicamento psiquiátrico, medicamento controlado, para nenhum paciente que chegue para mim primeiro. $\mathrm{Eu}$ encaminho e depois que (o paciente) vem com a receita, eu acompanho, mas dentro dessa prescrição (GRUPO 2, 2008, p. 1-20).

Ocorrem tanto encaminhamentos a profissionais especializados, atuantes em outro nível de atenção 
da equipe local, como o ato de repetir prescrições do atendimento anterior na USF. Para Valentini (2004), esse posicionamento promove uma fuga dos critérios formais para se estabelecer a terapêutica e gera um risco maior de dependência aos psicofármacos. A nosso ver, ele pode significar, também, um facilitador do acesso da medicação ao usuário do sistema.

Além do ato de prescrever o medicamento, conhecê-lo foi um recurso do cuidado, usado pelas equipes de saúde da família, tendo em vista a orientação e o monitoramento do usuário quanto ao seu uso. Os participantes da pesquisa falaram sobre usuários do serviço que utilizavam diversos tipos de medicamentos em concomitância aos psicotrópicos, acentuando a necessidade de educação para o autocuidado, conforme podemos ver a seguir:

- Eles perguntam muito sobre o remédio. [...]

- Eu sei para que serve Paracetamol. Mas aí ela pode passar outro remédio que eu não sei. Eu digo: - Ah, eu não sei. Eu vou procurar saber. Como eu chego, às vezes, e pergunto: - Ô doutora, a senhora passou esse remédio aqui. Para que é? Ela vai me dizer. Mas se eu não souber ou se ela não estiver no momento? O paciente não vai tomar enquanto eu não descobrir. Porque nem todos eles saem da sala ali, sabendo realmente do que se trata [...] Se eles saírem com 3, 4 comprimidos, aí, é que eles não sabem mesmo. Para que é? Que horas vão tomar? Então a gente precisaria disso (GRUPO 2, 2008, p. 1-20).

Essas falas mostram que, nesses casos, não saber, necessariamente, não redunda em não fazer. 
Há no cotidiano do trabalho das equipes de saúde da família movimentos em direção ao cuidar que superam a insuficiência do conhecimento.

Outro tipo de sentido construído em torno da demanda por conhecimentos sobre as medicações psicotrópicas se aproxima do paternalismo e implica uma postura reducionista frente à pessoa com algum tipo de sofrimento mental. Vejamos a fala a seguir:

- O médico dá a receita, se alguém precisar eu pego. Eu falo: por favor, pelo amor de Deus, faz de conta que eu sou a mãe de vocês, vão lá em casa pedir o remédio. Aí quando são oito horas eles jantam, eles vão lá em casa tomar o remédio e eu dou a água (GRUPO 1, 2008, p. 1-21).

Essa forma de significar o outro, comumente, limita o cuidado à tutela, à vigilância, ao controle da medicação. Isto, se incorporado à vida daquele que é dessa forma significado, pode aprisioná-lo numa relação de poder em que ele assume o lugar de submisso (SOUZA, 2004).

Os sentidos das demandas por conhecimento acerca das medicações psicotrópicas, aqui construídos, lembram a fala de Monteiro, Figueiredo e Machado (2009), quando afirmam que ele é importante para autonomizar tanto o profissional quanto o usuário em suas estratégias de enfrentamento diante da doença. A participação do usuário em seu tratamento contribuiria para o uso racional de medicamentos, potencializando o caráter terapêutico dos mesmos e a segurança dos pacientes em utilizá-los, haja vista as constantes interações de substâncias psicotrópicas (prescritas ou 
não) a que se submetem. Além disso, refletir sobre a psicofarmacoterapia pode ser útil à significação que se dá ao fato de se tomar um fármaco carregado de sentidos e estigmas.

\section{Conhecer para intervir sobre o processo saú- de/doença mental}

Essa categoria foi construída mediante conteúdos que abordavam a necessidade de identificar um sujeito em sofrimento psíquico, e de saber sobre os fatores desencadeantes do adoecimento mental, bem como as possíveis formas de tratamento e prevenção.

Para as equipes de saúde da família, o (des) conhecimento em relação a estes aspectos do adoecimento mental explicava o sentimento de medo e as inquietações sobre o assunto, dentre elas: "Quais doenças existem?", "Quando é doença?", "Como a doença surge?”, “É possível preveni-la?”.

Foi interessante constatar que essa demanda surge, principalmente, do desejo de se sentir seguro frente à pessoa com transtorno mental. Seguro, significando certo de sua ação e protegido de uma possível agressão. O conhecimento, nessa circunstância, retiraria o medo durante a ação de cuidar, possibilitando que este ato ocorra de forma menos ansiogênica para ambos os atores da cena, como podemos ver exemplificado na fala a seguir:

- Eu, na realidade, tenho medo. Porque eu não sei como lidar com essas pessoas. Eu gostaria de saber mais sobre o problema do 
doente mental, para que também eu possa saber como cuidar e para que também eu possa vir a acabar com esse medo que eu tenho do meu próximo (GRUPO 1, 2008, p. 1-20).

Outras falas trazem, no seu bojo, a demanda de identificar o início do processo de adoecimento para evitá-lo. A lógica de atuação da Estratégia de Saúde da Família na intervenção de base territorial para diminuir a ocorrência do adoecimento parece estar presente no modo destas equipes pensarem a saúde mental.

O trecho a seguir indica a preocupação em identificar fatores que causam o adoecimento mental:

- Ele se recusa a qualquer coisa, e era uma pessoa normal. O que acontece com a pessoa dele? Como ficou assim? Quais os sintomas? É possível identificar antes de adoecer? [...] Por que as pessoas adoecem de uma hora para outra, é possível saber antes? O que fazer? (GRUPO 6, 2008, p. 1-10)

Há a preocupação em conhecer para estar junto. A desconstrução do medo e a construção do vínculo são partes do desejo de conhecer e compôs mais duas categorias acerca da demanda por aprendizagem em saúde mental.

\section{Agir sem preconceito ao considerar a necessidade de se trabalhar o medo}

Algumas falas relacionadas ao medo, gerado por desconhecimento do que está causando o comportamento desviante, colocam o cuidado com a pessoa em 
sofrimento mental como uma atividade penosa. Há um empobrecimento dessa relação de cuidado entre o usuário e a equipe do serviço: "Tinha medo até de ir visitar porque ele sozinho, todo assim com a característica mesmo de doente mental, todo maltrapilho. Não é?” (GRUPO 1, 2008, p. 1-21).

Pensar o medo é pensar o que traz o sofrimento humano. É outra forma de nomear a insegurança, o incerto, o que foge ao controle (BAUMAN, 2008). Partindo desse entendimento, saber sobre quem sofre, sobre seu sofrimento e sobre possibilidades de cuidado a este sofrimento, na perspectiva da Equipe de Saúde da Família, significa amenizar o desconforto durante o trabalho. Este desejo de saber, originado da reflexão sobre as vivências do trabalhador em saúde, é o requisito primordial para produzir alternativas de práticas e de conceitos (CECCIM, 2005).

Desse modo, refletir sobre o medo durante o atendimento ao portador de transtorno mental significa um ganho, à medida que este sentimento potencialmente gera movimentos de aprendizagem e não imobilidade. $\mathrm{O}$ fator gerador do medo, que se procura afastar, deve ser não a pessoa, mas o desconhecimento acerca dela. Postura observada na fala:

- Simplesmente teve uma vez que a mulher, isso já era outra doida que me encontrou na rua. Eu corri. Eu correndo e ela atrás de mim. Se eu soubesse como abordar, eu parava, mas [...]. Vocês estão entendendo? É complicado. Então eu acho interessante a gente saber como é essa abordagem, como a gente vai, se acontecer algum caso assim, como a gente 
vai fazer? Qual o procedimento pra deixar ele mais calmo (GRUPO 2, 2008, p. 1-20).

Esse caminho não aponta apenas para o alívio do desconforto do profissional, mas principalmente para o sofrimento do usuário e sua família. Isso justifica que se destaque do texto acima a seguinte fala: Se eu soubesse como abordar, eu parava, mas [...], explicitando que o desconhecimento acerca do que fazer é que priva o doente do cuidado e não o simples 'medo de doido'.

A vontade de poder manejar tecnologias de cuidado é um ponto fundamental para a produção pedagógica, conforme vemos em Freire (1996, p. 32), quando nos convida a pensar este desejo como matéria prima do fazer educativo crítico, da proteção contra os "irracionalismos":

Como manifestação presente a experiência vital, a curiosidade humana vem sendo histórica e socialmente construída e reconstruída. Precisamente porque a promoção da ingenuidade para a criticidade não se dá automaticamente, uma das tarefas precípuas da prática educativa-progressista é exatamente o desenvolvimento da curiosidade crítica, insatisfeita, indócil. Curiosidade com que podemos nos defender de 'irracionalismos' decorrentes do ou produzidos por certo excesso de 'racionalidade' de nosso tempo altamente tecnologizado. E não vai nesta consideração nenhuma arrancada falsamente humanista de negação da tecnologia e da ciência. Pelo contrário, é consideração de quem, de um lado, não diviniza a tecnologia, mas, de outro, 
não a diaboliza. De quem a olha ou mesmo a espreita de forma criticamente curiosa (grifos do autor).

\section{Desenvolver tecnologias de "aproximação"}

Essa categoria surgiu como um produto da demanda das Equipes de Saúde da Família por se responsabilizarem pelo usuário que sofre mentalmente; daí, a aprendizagem sobre as tecnologias de aproximação.

Uma das tecnologias foi o vínculo, entendido como um mecanismo de redirecionamento do modelo de atenção do profissional para as necessidades da população (MIASSO; CASSIANI; PEDRÃO, 2007), além de facilitador do desempenho de suas funções no ato de cuidar. No fragmento a seguir, pode-se perceber exemplo dos sentidos dados a essa demanda:

- Então, a dificuldade maior é essa: aproximar. Porque tem que ter um certo começo para a gente se aproximar daquela pessoa, até da família. Porque você não vai chegar na casa da pessoa do nada, mesmo sendo que aquela pessoa tem problema de saúde. Então, é aproximar mesmo (GRUPO 3, 2008, p. 1-15).

Essa aproximação, de acordo com os trechos de fala descritos a seguir, clama por alguma tecnologia de "chegar". O que pode ser uma linguagem especial para estabelecer contato com a pessoa, uma maneira de se comportar.

- Mas em recursos humanos, aprender pelo menos a linguagem que eles usam, para a 
gente entrar e ver como conseguem aprender. Aprender como lidar com eles, para ver o que se pode fazer. Aprender a linguagem. É isso (GRUPO 1, 2008, p. 1-21).

- Eu fico assim: como lidar com o doente mental? Às vezes a gente fica sem saber como chegar, como conversar, o que falar. Acho que são esses questionamentos (GRUPO 3, 2008, p. 1-15).

Nestas narrativas, a pessoa com transtorno mental é apresentada como um sujeito separado do contexto do profissional, alguém que tem uma linguagem própria. Esse sujeito parece ser identificado como pertencente a uma "tribo" com aspectos culturais próprios, enquadrado num leque de preconceitos ainda arraigados na sociedade. No entanto, ressaltamos que as posturas produzidas ainda garantem algum tipo de atenção aos usuários e suas famílias. Querer conhecer quem é e o que interessa ao outro, expressa um desejo de se tornar familiar a ele - o que gera cuidado. Ao contrário seria se o desejo fosse de tornar aquele que sofre em sua diferença em alguém que é familiar - o que gera violência.

Atuar como facilitadores da inclusão social

Essa categoria agrupa os sentidos de demanda por aprendizagem em saúde mental de Equipes de Saúde da Família, quando elas consideram a necessidade de saber como contribuir para a efetivação do processo de inclusão social de pessoas em sofrimento mental grave. 
No trecho a seguir, pode-se constatar o "doente mental" sendo (res)significado como pessoa que deve estar ativamente no contexto social.

- Eu acho assim: como acompanhar esse paciente? Eu estou colocando, também, médicos, a equipe como um todo. Como a gente acompanhar esse paciente? Como a gente pode promover ou facilitar a reintegração desse doente mental à sociedade? (GRUPO 3, 2008, p. 1-15)

A pergunta que se evidencia é: o que preciso saber para fazer isto?

A inclusão social dessas pessoas tem se mostrado como uma ação extremamente complexa que não traz em seu questionamento respostas que podem ser construídas de maneira generalista. Exige espaços de discussão e formação que levem em conta, de forma crítica, os desejos de uma sociedade que pressiona para a normalização e para o enquadramento (ALVERGA; DIMENSTEIN, 2006). A questão que se coloca é: incluir os loucos ou lutar contra a sua exclusão do meio social? São duas frentes de atuação que exigem investimentos em diversos setores.

\section{Desenvolver habilidades de manejo frente ao usuário de álcool e outras drogas}

Esta categoria temática surgiu de conteúdos emergentes das falas de todas as equipes de saúde da família investigadas. De acordo com Becker (1976) e Malheiro (2010), as Substâncias Psicoativas (SPA) trazem inúmeras consequências psicossociais aos 
seus usuários, comerciantes e produtores, apontando para a necessidade da ESF atuar como importante agente mediador na minimização das consequências danosas. Contudo, falta qualificação profissional, apesar da boa vontade, para atuar na prevenção primária contra a dependência de SPA. Esse fato foi constatado nas falas das Equipes de Saúde da Família, como exemplificam os trechos:

- Alcoolismo que é da nossa labuta do dia a dia (GRUPO 4, 2008, p. 1-13).

- E tem muito alcoólatra, a gente tem que saber lidar bem com essas pessoas. Quando você chega na casa e eles são muitos. Eles ficam naqueles grupinhos assim, tudo inchado (GRUPO 2, 2008, p. 1-20).

- E também o adolescente, ele já começa a beber muito cedo por falta de opção. Ele não tem nada na vida. Não teve oportunidade, às vezes a única opção é beber, então quando ele fica adulto ele fica com problema. Aí, o que é que a gente poderia trabalhar na adolescência para que ele achasse outra coisa que não fosse o álcool para preencher a vida? (GRUPO 3, 2008, p. 1-15)

Para Barros e Pillon (2006), há lacunas na produção de conhecimentos e desenvolvimento de habilidades dos profissionais da ESF em incluir na prática clínica a dependência química e as suas consequências. Por isso, chamamos a atenção para a necessidade emergente de intervir nesse problema e, também, sobre os aspectos a ele relacionados. O uso de termos 
como "preencher a vida" de adolescentes nos leva a pensar em espaços de múltiplas aprendizagens, que atendam à demanda em tela e fomentem o desenvolvimento de projetos pautados no empreendedorismo social, no incentivo à leitura, no esporte e no lazer.

Assim, o atendimento a essa demanda envolve atividades de educação permanente, articuladas com profissionais de outros setores, dentre eles, educação, serviço social e turismo.

\section{Desenvolver habilidades de apoio às famílias}

Esta categoria considera a demanda de profissionais por conhecimentos para contribuírem com a produção de cuidado desenvolvida por familiares de pessoas em sofrimento mental, um grupo que é tanto mediador quanto carente da produção de saúde na ESF:

- Pode ser mais [conhecimento] do problema mental e, também, [sobre] como lidar com as famílias. Por quê? Como falei do rapaz que desestrutura a mãe. Ela fica nervosa e estressada e falou na vista dele em matar ou morrer. Ele falou assim: - Deus me livre mãe, eu fazer isso com minha mãe, quem faz isso? Aí, quer dizer, ele é agressivo porque tem um problema, e ela por causa do problema dele [...] Ele come demais e ela fica nervosa, ele não quer trabalhar, não quer ajudar o padrasto. Então, precisa saber como lidar, também, com a família (GRUPO 1, 2008, p. 1-21).

Essa fala traz situações do cotidiano de trabalho dos profissionais de saúde da família, nas quais 
a família precisa ser acolhida em aspectos que desafiam a capacidade resolutiva da ESF. Parte daí e de outros problemas, como o uso de álcool e outras drogas, a demanda pelo conhecimento dos dispositivos da rede social para auxiliar a família.

As necessidades, quando se trata da família, são diversas. Algumas estão, por vezes, num processo de adoecimento mais crítico que o indivíduo que é apontado como "paciente". Podemos constatar isso nos trechos a seguir:

- Eu tenho lá, há poucos meses, um rapaz com 21 anos. E ele começou com problemas de distúrbios mentais e isso foi trazendo transtorno pra própria família. E está sendo mesmo um caos, um caos mesmo [...]. O que pode fazer? Tem hora que eu olho assim pra eles, quem tá bom de tomar remédio também é vocês (os familiares) (GRUPO 1, 2008, p. 1-21).

- Na verdade, a família também não quer dar a medicação, se negando. Precisa de orientação para pai e mãe (GRUPO 1, 2008, p. 1-21).

Historicamente, a família era colocada à parte no tratamento, já que este ocorria no hospital psiquiátrico. Ter o doente no seio da família é uma situação nova para todos estes atores; somado a isto, há a crença na culpa da família pelo adoecimento (NAVARINI; HIRDES, 2008) presente, também, em reflexões que surgiram com os profissionais, como: "É genético?", "Dizem que é genético", ao se referirem ao sofrimento mental. 
Em outra situação, questiona-se sobre quem é a família, quando esta não é conhecida: “O que fazer, então?”.

- Aí, nesses casos eu fico assim, sem saber. Fui em A. (cidade) na casa do sobrinho dele, conversei. Ele disse: - Não, não vou acompanhar não, porque depois quando sair de lá, querem colocar dentro da minha casa, e eu não quero. Fui em C. (outra cidade) atrás do irmão por parte de pai. Não quis também. Aí... (GRUPO 1, 2008, p. 1-21).

- Ficou a gente de pés e mãos atadas, sem saber. Porque a família que era quem conhecia, não queria (GRUPO 1, 2008, p. 1-21).

Esta situação revela o nível de afastamento que pode ocorrer entre a família e o louco. As pessoas precisam saber lidar com comportamentos que fogem ao padrão e com as características com as quais os grupos familiares se configuraram enquanto atividades meio e também atividades fim do cuidado dos profissionais de saúde (NAVARINI; HIRDES, 2008).

No sentido contrário, parece ocorrer uma reação em cadeia: o profissional não sabe como lidar, a família não sabe como lidar e a pessoa "doente" acaba por não ser atendida em suas necessidades. Em consequência, surgem os riscos dos posicionamentos de imobilidade e/ou desresponsabilização, diante do abandono da família, em que parece ser justificável o abandono pela equipe.

É urgente, então, que a família seja copartícipe dos processos de educação em saúde na atenção básica, como sugerem as falas a seguir: 
- Então eu acho que o processo tem que ser contínuo. Treinamento tem que ser com a equipe toda (GRUPO 3, 2008, p. 1-15).

- Agora com a equipe, mas também com o cuidador. Acho que fazer um grupo de cuidadores (GRUPO 3, 2008, p. 1-15).

- Trabalhar com a família (GRUPO 3, 2008, p. 1-15).

Essas questões esclarecem a demanda por ações pedagógicas que auxiliem os trabalhadores de saúde na abordagem clínica às famílias, sejam elas inscritas nos laços de consanguinidade, ou de afetividade, em seus vários aspectos de saúde e de adoecimento mental.

\section{Receber cuidados que promovam a saúde mental e o bem-estar, desenvolvendo o cuidar de si para cuidar de outros}

A categoria refere-se à demanda dos profissionais de saúde da família por conhecerem a si mesmos e de terem atendidas suas próprias necessidades de saúde mental, um pré-requisito para a produção de atos cuidadores ao outro que sofre.

Os repertórios que dão sentidos a essa demanda expressam um olhar para si, anterior ao olhar para o outro: "Conhecer sobre nós mesmos", uma necessidade que surge nas falas de todas as equipes investigadas: "Nós precisamos ser tratados primeiro". O conhecimento dos seus limites (e as formas de amenizar sofrimentos) é explicado como um pré-requisito para a prestação de cuidado à comunidade, exemplificado 
na fala: "Conhecimento sobre nós mesmos. Nos trabalhar. Temos que nos preparar para lidar com saúde mental" (GRUPO 5, 2009, p. 1-11).

Vê-se, nesta fala, um exemplo de que a inserção da saúde mental (assim como dos processos de educação permanente na área) deve ser orientada para as necessidades da equipe, fomentando o suporte instrumental que signifique cuidados com esses profissionais.

\section{Algumas considerações}

As demandas por conhecimento em saúde mental, produzidas nesta obra, partem de uma relação de convívio entre os profissionais de saúde da família e a comunidade. Refletem processos sociais complexos, dentre eles, a cultura manicomial e as angústias geradoras do sentimento de "não saber", frente aos problemas da área.

De certa forma, a expressão de angústia, do medo, da vontade de saber e de desconforto das equipes pareceu-nos um ganho quanto aos questionamentos e movimentos produzidos para a resolução dos problemas.

Assim, os temas e as dúvidas produzidas/levantadas indicam a importância do planejamento e do desenvolvimento de ações de ensino e aprendizagem em saúde mental, fundamentadas no cotidiano de trabalho das equipes de saúde da família.

As demandas aqui explicitadas poderão ser um ponto de partida na (re)orientação dessas ações, com indicativos de lacunas como também de recursos para esse processo. Valorizam, pois, o conhecimento que se constrói no cotidiano para os processos de compartilhamentos de saberes e de práticas em saúde mental. 
Assim, esta produção pode ser captada e compartilhada por níveis hierárquicos de decisão que beneficiem, por meio da qualificação permanente em saúde mental, uma parcela maior da população trabalhadora e usuária dos serviços de saúde na Bahia e em outros estados do Brasil.

\section{Referências}

ALVERGA, A. R.; DIMENSTEIN, M. A reforma psiquiátrica e os desafios na desinstitucionalização da loucura. Interface, Botucatu, v. 10, n. 20, p. 299-316, jul./dez. 2066.

BARROS, M. A.; PILLON, S. C. Programa de Saúde da Família: desafios e potencialidades frente ao uso de drogas. Revista Eletrônica de Enfermagem, v.8, n.1, p. 144-149, jul. dez. 2006. Disponível em: <http://www.fen. ufg.br/fen_revista/revista8_1/sumario.htm>. Acesso em: 2 out. 2013.

BAUMAN, Z. Medo líquido. Tradução Carlos Alberto Medeiros.Rio de Janeiro: Zahar, 2008.

BECKER, H. Consciência, poder e efeito da droga. In:

Zahar, 1976. . Uma teoria da ação coletiva. Rio de Janeiro:

BRASIL. Ministério da Saúde. Secretaria de Atenção à Saúde. DAPE. Coordenação Geral de Saúde Mental. Reforma psiquiátrica e política de saúde mental no Brasil. Documento apresentado à Conferência Regional de Reforma dos Serviços de Saúde Mental: 15 anos depois de Caracas. Brasília, DF: Ministério da Saúde, 2005. Disponível em: <http://bvsms.saude.gov.br/bvs/publicacoes/relatorio15_anos_caracas.pdf >. Acesso em: 2 out. 2013. 
CAMPOS, G. W. S. Papel da rede de atenção básica em saúde na formação médica - Diretrizes. Cadernos ABEM, Rio de Janeiro, v. 3, p. 6-10, out. 2007.

CECCIM, R. B. Educação permanente em saúde: desafio ambicioso e necessário. Interface - Comunicação, Saúde, Educação, Botucatu, v. 9, n. 16, p. 161-177, set. 2004- fev. 2005.

FREIRE, P. Pedagogia da autonomia: saberes necessários à prática educativaSão Paulo: Paz e Terra, 1996. (Coleção Leitura).

\section{GRUPO 1. Projeto Construção Social da Aprendiza-} gem acerca da Saúde Mental e Saúde da Família: grupo de discussão [maio 2008]. Moderadores: Rozemere Cardoso de Souza e Erika Antunes Vasconcellos. Jequié: Uesc: Fapesb, 2009, gravador digital. p. 1-21.Grupo de discussão produtor sobre a inserção da saúde mental na Estratégia de Saúde da Família.

GRUPO 2. Projeto Construção Social da Aprendizagem acerca da Saúde Mental e Saúde da Família: grupo de discussão [ago. 2008]. Moderadores: Rozemere Cardoso de Souza e Erika Antunes Vasconcellos. Ilhéus: Uesc: Fapesb, 2009, gravador digital. p. 1-20.Grupo de discussão produtor sobre a inserção da saúde mental na Estratégia de Saúde da Família.

GRUPO 3. Projeto Construção Social da Aprendizagem acerca da Saúde Mental e Saúde da Família: grupo de discussão [abr. 2008]. Moderadores: Rozemere Cardoso de Souza e Erika Antunes Vasconcellos. Vitória da Conquista: Uesc: Fapesb, 2009, gravador digital. p. 1-15. Grupo de discussão produtor sobre a inserção da saúde mental na Estratégia de Saúde da Família. 
GRUPO 4. Projeto Construção Social da Aprendizagem acerca da Saúde Mental e Saúde da Família: grupo de discussão [maio 2008]. Moderadores: Josenaide Engracia dos Santos. Feira de Santana: Uesc: Fapesb, 2009, gravador digital. p. 1-13. Grupo de discussão produtor sobre a inserção da saúde mental na Estratégia de Saúde da Família.

GRUPO 5. Projeto Construção Social da Aprendizagem acerca da Saúde Mental e Saúde da Família: grupo de discussão [maio 2009]. Moderadores: Josenaide Engracia dos Santos. Salvador: Uesc: Fapesb, 2009, gravador digital. p. 1-11.Grupo de discussão produtor sobre a inserção da saúde mental na Estratégia de Saúde da Família.

\section{GRUPO 6. Projeto Construção Social da Aprendiza-} gem acerca da Saúde Mental e Saúde da Família: grupo de discussão [novembro 2008]. Moderadores: Josenaide Engracia dos Santos. Salvador: Uesc: Fapesb, 2009, gravador digital. p. 1-10. Grupo de discussão produtor sobre a inserção da saúde mental na Estratégia de Saúde da Família.

MALHEIRO, L. S. B. Sacizeiro, usuário e patrão: um estudo etnográfico sobre consumidores de crack no Centro Histórico de Salvador. 2010. Trabalho de Conclusão de Curso (Graduação em Antropologia)- Departamento de Antropologia, Faculdade de Filosofia e Ciências Humanas, Universidade Federal da Bahia, Salvador, 2010.

MIASSO, A. I.; afetivo CASSIANI, S. H. B.; PEDRÃO, L. J. Estratégias adotadas por pessoas com transtorno bipolar e a necessidade de terapêutica medicamentosa. Revista de Enfermagem, Rio de Janeiro, v. 11, n. 4, p. 240- 248, out./dez. 2007. 
MONTEIRO, M. M.; FIGUEIREDO, V. P.; MACHADO, M. F. A. S. Formação do vínculo na implantação do Programa Saúde da Família numa Unidade Básica de Saúde. Revista Escola de Enfermagem, São Paulo, v. 43, n. 2, p. 358-364, jun. 2009.

NASCIMENTO, A. A. M.; BRAGA, V. A. B. Atenção em saúde mental: a prática do enfermeiro e do médico do Programa Saúde da Família de Caucaia-CE. Cogitare Enfermagem, Recife, v. 9, n. 1, p. 84-93, 2004. Semestral.

NAVARINI, V.; HIRDES, A. A família do portador de transtorno mental: identificando recursos adaptativos.

Texto \& Contexto Enfermagem, Florianópolis, v. 17, n. 4, p. 680-688, jul./dez. 2008.

NUNES, M.; JUCÁ, V. J. ; VALENTIM, C. P. B. Ações de saúde mental no Programa Saúde da Família: confluências e dissonâncias das práticas com os princípios das reformas psiquiátrica e sanitária. Cadernos de Saúde Pública, Rio de Janeiro, v. 23, n. 10, p. 2375-84, out. 2007.

RIBEIRO, C. S. et al. Chronic use of diazepam in primary healthcare centers: user profile and usage pattern. São Paulo Medical Journal, São Paulo, v. 125, n. 5, p. 270-274, set. 2007.

ROTELLI, F. Desinstitucionalização uma outra via: a reforma psiquiátrica italiana no contexto da Europa Ocidental e dos "países avançados". In: NICÁCIO, F. (org.). Desinstitucionalização. São Paulo: Hucitec, 1990.

SILVA, G. A. Atuação dos profissionais da rede especializada em Saúde Mental de Goiânia - GO. 2010. Dissertação (Mestrado em Enfermagem)- Faculdade de Enfermagem, Universidade Federal de Goiás, Goiânia. 2010. 
SOUZA, R. C. Produção de sentidos por profissionais de saúde da família acerca do doente mental e dos cuidados a ele dirigidos. 2004. Tese (Doutorado em Enfermagem) - Escola de Enfermagem de Ribeirão Preto, Universidade de São Paulo, Ribeirão Preto, 2004.

VALENTINI, W. et al. Treinamento de clínicos para o diagnóstico e tratamento da depressão. Revista de Saúde Pública, São Paulo, v. 38, n. 4, p. 523-528, ago. 2004. 

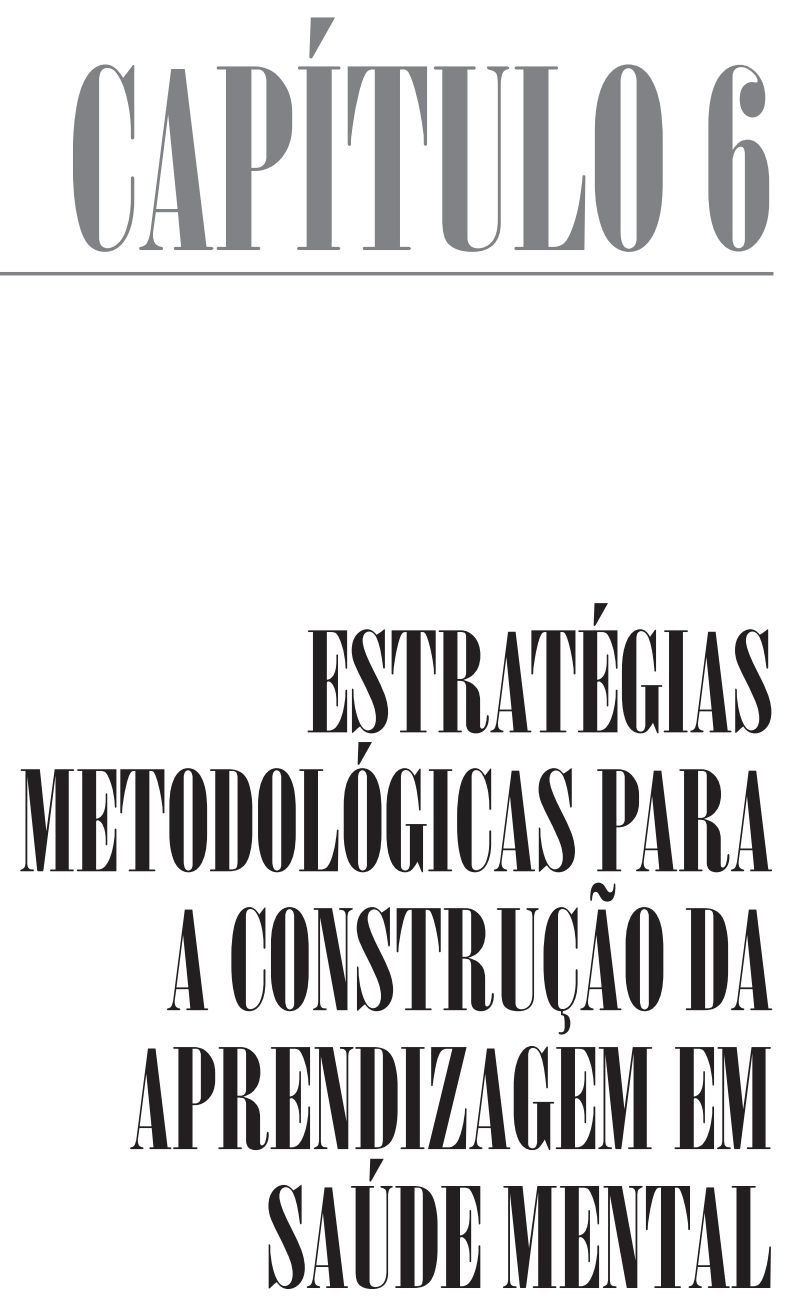

Vivitine dos Sint os Soutzit Gieorge Imilirial Sintos Latrliria Regia Oliverita Corderiro 


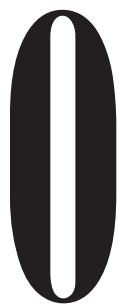

contexto de mudança paradigmática na atenção em saúde mental traz consigo a necessidade de se buscar novas estratégias metodológicas e/ou pedagógicas para a construção do processo de ensino/aprendizagem comprometido com os princípios da atenção psicossocial e do Sistema Único de Saúde (SUS). Neste sentido, tal processo pressupõe certa desterritorialização dos profissionais da área, que deve refletir em mudança nas práticas e, consequentemente, nos saberes que direcionam os fazeres no cotidiano.

Vale salientar que a construção de saberes e práticas com potencial de transformação não é tarefa fácil, pois exige uma desconstrução do paradigma psiquiátrico, o qual ainda influencia a permanência de costumes manicomiais por tratar-se de uma construção socio-histórica. Dessa maneira, entendemos que a reforma da atenção em saúde mental implica uma nova construção social acerca das questões relacionadas ao processo saúde-adoecimento mental. Acreditamos que o seu paradigma será consolidado através dos processos de ensino e aprendizagem construídos nas relações entre docentes, discentes, profissionais, usuários dos serviços, familiares e sociedade em geral. Decorre disso a necessidade de se investir também em estratégias metodológicas e/ou pedagógicas com potencial de transformação social.

Nessa perspectiva, corroboramos com Amarante (1999), no sentido de que o desafio de instituir movimentos impulsionadores de mudanças deve abranger pelo menos três dimensões, descritas por ele como campos fundamentais da reforma da atenção 
em saúde mental, a saber: (i) campo teórico-conceitual, que envolve a desconstrução de conceitos e concepções fundantes da psiquiatria e reconstrução de saberes pautados no paradigma da saúde mental; (ii) campo técnico-assistencial, a partir de e simultaneamente à reconstrução dos saberes, a construção de uma rede de novos serviços e não apenas isso, mas espaços de sociabilidade, de trocas e produção de subjetividades, substitutivos ao modelo terapêutico tradicional; (iii) campo sociocultural, associado aos movimentos anteriores, pressupõe transformar o imaginário social em relação à loucura.

Nesta perspectiva, a Estratégia de Saúde da Família apresenta-se como espaço propício para a construção de conhecimento em saúde mental e para experimentação de práticas inovadoras nesse campo de atenção/cuidado. Ao considerar a indissociabilidade entre teoria e prática, é notório que a construção de saberes ocorre de forma concomitante à produção do cuidado, no fazer cotidiano dos profissionais da ESF, o que implica no próprio processo de trabalho e na valorização de suas experiências e vivências no território, produzindo, assim, aprendizagem significativa através da educação permanente em saúde.

Acreditamos que a pesquisa se caracteriza como um dispositivo para a construção de conhecimento acerca das estratégias facilitadoras do processo de ensino-aprendizagem em saúde mental, que possam atender às demandas das equipes de saúde da família e às necessidades de cuidado da população. Como refere um profissional de uma das Equipes de Saúde da Família: 
- Hoje está acontecendo a coleta de dados, que vocês vão analisar. Esperamos que na próxima visita, vocês venham com oficinas, dinâmicas, algo que nos ensine como lidar com essas pessoas (GRUPO 1, 2008, p. 1-21).

Nesta perspectiva, o presente capítulo abordará as formas de ensino e aprendizagem construídas pelas Equipes de Saúde da Família, analisando-as com vistas aos seguintes aspectos: $i$ ) a aprendizagem significativa como pressuposto pedagógico da educação permanente em saúde; ii) o desconforto que emerge do cotidiano das práticas de cuidado em saúde mental como força propulsora da produção pedagógica nessa área; iii) o apoio matricial como estratégia educativa para a democratização do conhecimento.

Sendo assim, objetivamos indicar as estratégias apontadas por essas equipes. A presença de especialistas e a existência de práticas que possam compor tarefas e características do cuidado são descritas como facilitadores para que os profissionais construam suas experiências. As estratégias envolvem situações compartilhadas entre atores sociais em torno do alcance dos objetivos da reforma da atenção em saúde mental.

\section{O desconforto como força propulsora da pro- dução pedagógica: o (re)fazer cotidiano das práticas de cuidado em saúde mental}

A construção do conhecimento surge da necessidade de resolução de problemas que se apresentam no cotidiano pessoal. Não é um processo automático, requer um investimento ativo e cooperativo entre os 
indivíduos que se relacionam num contexto de necessidades, que são a essência do problema, e problematizar o problema é a essência da construção do conhecimento (GERGEN, 2009).

A reforma psiquiátrica brasileira coloca o cuidado em saúde mental como incumbência dos serviços de base territorial e comunitária, o que em nossa realidade traduz-se em Estratégia de Saúde da Família (ESF), Programa de Agentes Comunitários de Saúde (Pacs), Centros de Atenção Psicossocial (Caps), dentre outros. Importa-nos o fato de que destes serviços, o de maior penetração no território, e com maior contato com o problema em que se constitui o adoecimento mental, é a ESF, uma vez que lida, cotidianamente, com famílias que convivem com algum processo desse adoecimento mesmo que nem sempre tenha condições de dar conta desta tarefa (BRASIL, 2005).

Observa-se este aspecto nas falas das equipes da ESF, a seguir:

- Outras doenças que a gente já convive no dia a dia, a gente tem um treinamento. Eu acho que a saúde mental também deveria ter (GRUPO 2, 2008, p. 1-21).

- Eu acho que a convivência com a situação é o que te faz aprender de verdade. Eu acho que o suporte teórico, em relação a isso, é você ter uma abordagem do paciente como um todo e não ver ele isolado. Ele está aqui dentro de uma família. Então, o Programa de Saúde da Família, médicos, enfermeiros, vão estar lidando com a família, vão estar lidando 
com o paciente. Ele tem que ser visto como um todo. E não pode estar dando o suporte só de abordagem da doença. Tem que ver o aspecto emocional. Essa é uma abordagem que é indispensável pra você estar percebendo o doente, escutando o doente. Eu acho que esse tipo de abordagem tem que ter. Tem que ter o suporte da área de psiquiatria, da área de psicologia e da família. É o dia a dia, você ter conhecimento dos problemas que você vai lidar (GRUPO 2, 2008, p. 1-21).

Deparar-se com uma família que convive com o adoecimento mental provoca nos profissionais uma diversidade de posturas, em sua maioria, objetivando solucionar algo que se apresenta como problemático, seja para as famílias, seja para o próprio trabalho destes sujeitos. Quando mencionamos a necessidade de solucionar algo no processo de trabalho, nos referimos ao desconforto que as situações-problema provocam nos trabalhadores em função deles não saberem a maneira mais adequada/resolutiva de lidar com a situação.

Este desejo de saber reclama ser agregado, de forma ativa e cooperada, ao processo de construção de conhecimento em saúde mental. É este desconforto que se apresenta nas situações de encontro entre profissional e sujeito/família em sofrimento que precisa encontrar ressonância nas discussões das equipes. O valor heurístico das situações do cotidiano de trabalho está em debruçar-se sobre elas, refletir sobre o problema, discutir as intervenções, ou seja, criar espaços para externar as tensões e afetamentos para que se tornem, de modo real, substrato para a produção de conhecimento. 
O risco está no fato deste desconforto tornar-se fator de paralisia das ações de cuidado e permanência dos trabalhadores na condição de insipientes, à medida que, inertes, permaneçam sob a apresentação de profissionais com medo do louco, com raiva do louco, com juízo de valor sobre seus atos, e insensíveis à condição de sofrimento mental, adoecendo, por não conseguir acolher as demandas que lhes chegam, dentre outras posturas disfuncionais para a produção de cuidado em saúde mental.

Desta forma, torna-se premente que as práticas em saúde sejam tomadas como referência para a elaboração de projetos educativos (PAIM, 2006), de modo que estes reflitam as dimensões objetivas da atenção em saúde mental.

A complexidade deste campo, permeado por lógicas distintas de modelos de atenção que se enfrentam num contexto de constantes disputas políticas e paradigmáticas, precisa encontrar respaldo nos modos de pensar os processos educativos na atenção básica à saúde. A educação, além de um ato de conhecimento, nesse sentido, assume-se como um ato político (SANTOS, 2005) voltado para a transformação social, que "ilumina" a realidade no contexto do desenvolvimento do trabalho intelectual.

Ceccim (2005, p. 167), tratando sobre a Educação Permanente em Saúde, reforça a ideia de que a produção de conhecimento advém dos abalos provocados nos profissionais pelo cotidiano de trabalho:

Se somos atores ativos das cenas de formação e trabalho (produtos e produtores das cenas, 
em ato), os eventos em cena nos produzem diferença, nos afetam, nos modificam, produzindo abalos em nosso 'ser sujeito', colocando-nos em permanente produção. O permanente é o aqui-e-agora, diante de problemas reais, pessoas reais e equipes reais (grifo do autor).

Em concordância, Merhy (2005, p. 173) escreve que:

E aí está o cerne de um grande novo desafio: produzir auto-interrogação de si mesmo no agir produtor do cuidado; colocar-se ético-politicamente em discussão, no plano individual e coletivo, do trabalho. $\mathrm{E}$ isto não é nada óbvio ou transparente.

Estes autores chamam a atenção para que os afetamentos e abalos que ocorrem durante a produção de cuidado sejam colocados em evidência e que, com isso, impulsionem um movimento de aprendizagem significativa e o consequente fazer criativo das instituições, de forma que os processos de trabalho sejam plásticos e condizentes com a realidade que se apresenta diariamente. Nota-se que não se dissocia a produção intelectual do trabalho em saúde, de sorte que um produz o outro num processo dinâmico e relacional.

O desafio para a produção intelectual do SUS está em fazer com que, a partir dos desconfortos dos trabalhadores na assistência, efetivem-se processos de educação permanente (BRASIL, 2004) que produzam inovações e mudanças nos serviços e nas práticas cotidianas do cuidado em saúde. 


\section{A aprendizagem significativa como um pressuposto pedagógico da educação permanente em saúde}

A Aprendizagem Significativa (AS) é definida por Ausubel (1982) como o processo em que o aprendente, ao entrar em contato com um conhecimento novo, relaciona-o de forma substantiva e não arbitrária a conceitos relevantes que já fazem parte de sua estrutura cognitiva. Esses últimos são chamados de conceitos subsunçores (ou conceitos âncora).

Dessa forma, o saber prévio do sujeito é a tônica do processo, implicando numa aprendizagem transbordante de realidade e impregnada de sentido.

Esse processo pedagógico, imbuído da realidade cotidiana de quem se dispõe a aprender, é o pressuposto primeiro da Educação Permanente em Saúde (EPS), sendo esta definida como processo educativo que ocorre no trabalho, a partir do contexto real das práticas sociais e laborais, modificando-as e ampliando a capacidade reflexiva das equipes e organizações (BRASIL, 2009).

A necessidade de uma educação permanente em saúde mental que vincule o conhecimento teórico às atividades práticas no território, pensando-as enquanto unidades indissociáveis, está explicitada nas falas de alguns profissionais da ESF:

- No caso de saúde mental, que vai abordar o lado psicológico, poderia ser também em módulos, assim: $1^{\circ}$ a abordagem e a gente iria para a área tentar ver; $2^{\circ}$ o treinamento, a gente poderia adquirir o conhecimento e levar pra 
prática. Porque quando nós nos juntarmos, creio que a experiência seria mais (GRUPO 2, 2008, p. 1-20).

- De forma conjunta, de forma sistemática e com discussões teóricas e todo mundo junto (GRUPO 4, 2008, p. 1-13).

- Aula inicial teórica, mas com prática (GRUPO 5, 2009, p. 1-11).

- Mas a aprendizagem tem que ter prática junto com a gente (GRUPO 5, 2009, p. 1-11).

As falas desses sujeitos referem-se, ainda, ao desejo de inclusão dos familiares e cuidadores no processo de aprendizagem:

- Treinamento tem que ser constante com a equipe toda (GRUPO 3, 2008, p. 1-15).

- Agora com a equipe e também com o cuidador. Acho que fazer um grupo de cuidadores (GRUPO 3, 2008, p. 1-15).

- Trabalhar com a família (GRUPO 3, 2008, p. 1-15).

Ausubel (1982) ainda estabelece condições básicas para que a Aprendizagem Significativa ocorra. A primeira delas é que o sujeito queira aprender. Viu-se, anteriormente, que os afetamentos pela realidade do trabalho são condição sine qua non para que a produção pedagógica se processe. Percebemos que os profissionais da ESF têm o desejo de saber lidar com o adoecimento mental, de abordar o sujeito em sofrimento, 
de auxiliar a família que convive com essa realidade, enfim, um desejo de conhecer, originado diretamente das problemáticas que se apresentam no território de trabalho das equipes.

Pode-se, então, dizer que os enfrentamentos cotidianos, potencialmente, criam terreno fértil para a Aprendizagem Significativa, à medida que promovem incômodos nos sujeitos e que, também potencialmente, os impelem a um movimento de busca ativa pelo aprendizado.

Cabe reafirmar que o sujeito, diante do medo por não saber, pode, em um movimento contrário à aprendizagem, paralisar-se ou afastar-se do problema apresentado em seu cotidiano de trabalho. Este engessamento também é prática não muito rara em nossos serviços de saúde, quando diante das faltas, a resolução do problema é posta em um stand by desresponsabilizado. Quando falamos em medo, fazemo-no conforme Bauman (2008), nos referindo ao sentimento diante daquilo que traz o sofrimento humano, como outra forma de nomear a insegurança, o incerto, o que foge ao controle.

Dessa forma, o conhecimento em saúde mental adquire o sentido de abrandamento do desconforto e, por isso, constitui-se como demanda importante durante a produção do cuidado. Neste sentido, os profissionais ressaltam, ainda, a necessidade de terem suporte instrumental e psicológico, bem como momentos de dispersão durante o processo de aprendizagem, como forma de aliviar as tensões e possibilitar momentos prazerosos: 
- Como as meninas colocaram aí, que tivesse um psicólogo. Muitas vezes ele poderia não assistir a todos. Mas ele poderia orientar os profissionais (GRUPO 2, 2008, p. 1-20).

- Agora acho que deveria ser extra-muro. Fora daqui. Como a gente fez o treinamento do PSF. Poderia ser um ou dois dias fora. Até integrando o grupo também, a gente. Poderia ser feito fora do serviço (GRUPO 2, 2008, p. 1-20).

- Nós fizemos um treinamento de PSF. Foi uma semana, teve várias atividades lúdicas, e a parte teórica. Foi muito bom e integrou também a equipe (GRUPO 2, 2008, p. 1-20).

A segunda condição básica para que ocorra a Aprendizagem Significativa é que o conceito a ser aprendido seja lógico e psicologicamente significativo (AUSUBEL, 1982). Lógico, em relação à natureza do conceito a ser descoberto e psicologicamente significativo no que diz respeito à idiossincrasia das estruturas cognitivas dos sujeitos. É nesta dimensão que cada aprendente percebe e relaciona de maneira própria os conceitos novos que se apresentam. Os conceitos âncora, a partir da problematização das situações, serão buscados ou emergirão de formas preponderantemente peculiares para, dessa maneira, interagirem com os novos conceitos e implicarem em outras possibilidades de conhecimento.

Em relação à aprendizagem teórico-conceitual, os profissionais trouxeram como demanda a necessidade de acesso a recursos e materiais didáticos sobre saúde mental, conforme as falas: 
- É, com materiais didáticos (GRUPO 1, 2008, p. 1-21).

- Sobre o assunto, apostilas, livros (GRUPO 1, 2008, p. 1-21).

- Quando for falar de alcoolismo, trazer o material de alcoolismo. Quando for falar sobre como lidar com a família do doente portador de doença mental, trazer algum material didático sobre o assunto que for abordado (GRUPO 1, 2008, p. 1-21).

Na última fala, percebemos que o texto - o material didático - surge como recurso para a produção de diálogos, quando a participante diz: "quando for falar...”. Logo, favorece a (re) construção conceitual acerca dos temas abordados, considerando que todo texto se insere em um contexto. Isso possibilita a vinculação do conhecimento às experiências dos atores envolvidos, expressas nas falas que perpassam às discussões teóricas e que subsidiam o processo de ressignificação presente no diálogo.

Considera-se, portanto, que os processos educativos pautados na EPS devem sempre partir de uma produção heterogênea de cuidado, ou seja, de um processo de produção idiossincrático, no qual os afetamentos são sentidos em escalas variáveis (CECCIM, 2005; FERREIRA et al., 2009). Nisto vê-se a grande relevância do processo de aprendizagem avocar para si os aspectos singulares de cada contexto de trabalho.

Como pressupostos que se articulam à EPS, temos o trabalho de Paulo Freire por, dentre outras razões, referir-se à educação de adultos e por remeter 
a um pensamento dialógico, dialético e relacional. Trazendo uma abordagem sociocultural do processo educativo, Freire (1982) o define como uma leitura interacionista entre o sujeito e o objeto do conhecimento, na qual o sujeito assume o papel de elaborador do conhecimento. Ressalta, ainda, a necessidade de, na leitura do texto (conceito lógico), explicitar-se o contexto (a realidade do leitor ou sua leitura de mundo) e que, a partir dele, relacionem-se texto e leitor para a produção de um novo texto. Desta forma, a educação configura-se, além de um ato de saber, como um ato político (SANTOS, 2005).

Como princípios metodológicos, Freire (1996) traz, ainda, o respeito pelo saber do educando e a conquista da autonomia. Para isto, toma como ponto de partida a cultura do indivíduo, no sentido de ampliar sua leitura de mundo, apontando para a compreensão de si enquanto protagonista da história.

Segundo o autor (1996), quando homens e mulheres se percebem "fazedores de cultura”, está vencido o primeiro passo da sua alfabetização política. E, nesta direção, é inevitável a tomada de posição frente ao seu contexto de vida, com suas problemáticas e desafios impostos, fomentando, assim, a existência de um forte conteúdo ideológico na construção de conhecimento.

Essa pedagogia, que vai de encontro à incorporação do conhecimento e ao modo bancário de educação, onde o educando é assumido como depositário de conhecimentos, possibilita a construção de conceitos que tenham significado no cotidiano de vida dos sujeitos. 
Isto significa, portanto, libertar-se de um conhecimento hegemônico e opressor, que gera a passividade diante dos problemas da vida, para dar lugar à modificação ativa da realidade, em um movimento de observação-reflexão-readmiração-ação (FREIRE, 1982).

Estes pressupostos pedagógicos, assumidos pela EPS, vêm apontar caminhos que promovam o "nascimento" de trabalhadores capazes de superar o modelo manicomial (BRASIL, 2005; PATTO, 1999), e que respondam à demanda por pessoal qualificado para protagonizar a implementação efetiva do Sistema Único de Saúde (PAIM, 2006).

Pôde-se verificar, através dos discursos das equipes da ESF participantes da pesquisa, que as propostas metodológicas para o processo educativo em saúde mental apontam para a necessidade de se efetivar a Política Nacional de Educação Permanente, no que diz respeito ao desenvolvimento dos profissionais do SUS, através de estratégias inseridas na realidade concreta do trabalho. Para tanto, deve-se transformar, além do modo de educandos e conceitos se relacionarem, o setting onde ocorre a aprendizagem. Emerge a necessidade de tornar mais plásticos os espaços de educação, para além dos Polos de Educação Permanente, salas de aula e módulos de Educação a Distância. Educandos, educadores e situações-problema precisam, portanto, habitar os territórios de atuação da Estratégia de Saúde da Família e dos Centros de Atenção Psicossocial. 


\section{O apoio matricial como estratégia educativa para a democratização do conhecimento acerca da saúde mental}

$\mathrm{O}$ apoio matricial pode ser entendido com um arranjo institucional que visa promover interlocução entre equipes especializadas e equipes da atenção básica, na perspectiva de oferecer suporte técnico e pedagógico, bem como favorecer a organização de serviços e processos de trabalho através da democratização do conhecimento especializado (GOMES, 2006).

Desse modo, o matriciamento tem como estratégias a interação com as equipes da atenção básica em seu território e o estabelecimento de iniciativas conjuntas para o levantamento de dados sobre os processos de saúde-doença no contexto local. Isso também implica em atender conjuntamente as situações complexas, com o estabelecimento de suporte pedagógico para a construção do conhecimento em saúde mental a partir das práticas desenvolvidas.

No que se refere ao suporte especializado em saúde mental, as Equipes de Saúde da Família enfatizam a importância desse tipo de apoio no processo de construção de saberes e práticas, como se observa nas falas que se seguem:

- Uma orientação conjunta e discussões de casos clínicos [...] e estratégias com a comunidade, mas de forma atuante (GRUPO 4, 2008, p. 1-13).

- Junto com a gente para não ficarmos sobrecarregados (GRUPO 4, 2008, p. 1-13). 
- Eu acho que treinamentos num processo contínuo, essa questão da integração como setor responsável pela doença mental é importantíssimo. [...] A gente tem um novo olhar. Então, eu acho que o processo tem que ser contínuo (GRUPO 4, 2008, p. 1-13).

- Eu acho que deve ter um profissional dentro do posto, que viesse para o posto para estar ajudando a gente com todos os problemas. Aqui, a gente não tem onde levar e com uma pessoa aqui dentro, tendo um contato direto com o CAPS, seria melhor. Ele vem formar essa parceria (GRUPO 5, 2009, p. 1-11).

- Reunia toda equipe e depois mostrava o que fazer, como acompanhar visita; um quadro de depressão e como abordar (GRUPO 5, 2009, p. 1-11).

- E o melhor momento com exemplos e atendendo junto com a gente (GRUPO 6, 2008, p. 1-10).

- Através de palestras de profissionais, do órgão responsável pela saúde para dar esse treinamento, para dar essas palestras. Só em ter pessoas que possam esclarecer pra gente algumas coisas (GRUPO 3, 2008, p. 1-15).

- O profissional junto com a gente orientando oficinas e como abordar. Não só aula (GRUPO 4, 2008, p. 1-13).

- Palestras de apoio à família, nos casos de drogas, nos casos de violência. Como intervir? Eu acho que as meninas precisam desse auxílio para abordagem (GRUPO 2, 2008, p. 1-20). 
Para dar sustentação a essa perspectiva de ajuda, o Ministério da Saúde determinou, através da Portaria n. ${ }^{0}$ 154, de 24 de janeiro de 2008, a criação dos Núcleos de Apoio à Saúde da Família (NASF), compostos por uma equipe multiprofissional com o objetivo de fornecer sustentáculo técnico-pedagógico e compartilhar com a ESF a produção de cuidado em áreas específicas da saúde, de forma a instrumentalizar suas equipes para o atendimento às necessidades de cuidado das famílias de seu território, assumindo, assim, uma postura de corresponsabilização.

Contudo, os NASF ainda se encontram em processo de implantação e, nesta perspectiva, não se configuram como uma realidade em alguns municípios que compuseram o cenário da pesquisa, como expresso na seguinte fala:

- Eu fiquei sabendo que os NASF que estão sendo criados têm todas as profissões que a população precisa, mas acho que na equipe poderia introduzir um assistente social, psicólogo, terapeuta que seriam figuras importantíssimas. Mas enquanto isso não ocorre a gente vai fazendo e aprende a fazer as coisas nas práticas, erra nas práticas e a partir das vivências que nós tivemos, a gente sistematiza no dia a dia (GRUPO 5, 2009, p. 1-11).

Apesar de o profissional enfatizar a importância do NASF, ele reforça a ideia de que o processo ensino-aprendizagem é construído no fazer cotidiano dessas equipes, através da valorização dos conhecimentos advindos das experiências prévias desses 
especialistas. Percebe-se, assim, que toda prática comporta um saber e que mesmo os erros podem ser propulsores de aprendizagem e favorecedores de processos de mudanças.

A problematização das dificuldades e falhas percebidas pelos profissionais no processo de produção de cuidado em saúde mental os desperta para a reflexão sobre suas práticas. Tais reflexões possuem potencial para mobilizar o pessoal da ESF em busca de suporte especializado. Essa articulação entre a atenção básica e os serviços especiais é fundamental para e efetivação dos princípios da reforma da atenção em saúde mental, entendendo que os trabalhadores da atenção básica ocupam um lugar estratégico no desenvolvimento das ações de prevenção, promoção, reabilitação psicossocial e vigilância.

O matriciamento na saúde mental rompe com a especialização verticalizada, democratiza o conhecimento, e compartilha a responsabilidade pela atenção. Assim, favorece a construção de conhecimento na área através da criação de espaços de encontros que potencializam a circulação de saberes e auxiliam as equipes para a implementação da clínica ampliada. Neste contexto, deve atuar na perspectiva de trazer a atenção à saúde mental para o cenário comunitário, evitando encaminhamentos desnecessários para os serviços de maior complexidade.

O processo de matriciamento volta-se, portanto, para a democratização do conhecimento especializado no espaço coletivo, sendo que as metodologias implementadas devem estar de acordo com a necessidade de todos os atores envolvidos. 
Nesta pesquisa, as equipes de saúde da família indicaram algumas estratégias de aprendizagem em saúde mental, sendo que a maioria envolve o suporte especializado como favorecedor do processo de construção do conhecimento nessa área de atuação, dentre elas destacam-se: capacitações com utilização de metodologias participativas de ensino; abordagens que traduzam o cotidiano de trabalho em conhecimento; cursos teórico-práticos; desenvolvimento de grupos de trabalho com familiares e cuidadores; e suporte instrumental e psicológico aos profissionais da ESF.

Além do exposto, o apoio matricial proporciona a atuação interdisciplinar no atendimento às demandas de cuidado, rompendo com a lógica da referência e contrarreferência que gera desresponsabilização dos trabalhadores nesse contexto de atuação.

O processo de implantação desta estratégia perpassa uma gama de entraves que precisam ser superados para que possam estabelecer ações eficientes e promover atenção à saúde com qualidade. Dentre os entraves a serem superados, alguns estudos apontam a falta de preparo prévio das equipes apoiadoras para atuação como facilitadoras do processo de aprendizagem das equipes de referência que, em função disso, acabam atuando como recursos humanos substitutivos das falhas na rede. Desta forma, é interessante refletir sobre a necessidade de transposição da formação do trabalhador em saúde especializado para um trabalhador coletivo que possibilite espaços de trocas no serviço e se comprometa com as mudan- 
ças na atenção à saúde (BEZERRA; DIMENSTIEN, 2008).

Esse processo recente de implementação do apoio matricial já tem mostrado resultados positivos na atuação conjunta com profissionais da área e comunidade, configurando-se como uma demanda das equipes da ESF e também como estratégia metodológica para a construção da aprendizagem e inclusão da atenção em saúde mental.

Ao lado desse fato, lembramos, aqui, que o objetivo central do processo ensino-aprendizagem em saúde mental deve ser a (re) construção de práticas de cuidado que possibilitem a reabilitação, o social, o resgate da cidadania e a atenção integral à saúde das pessoas e famílias em sofrimento mental.

\section{Referências}

AMARANTE, P. Manicômio e loucura no final do século e do milênio. In: FERNANDES, M. I. A.; SCARCELLI, I. R.; COSTA, E. S. (org.). Fim de século: ainda manicômios? São Paulo: IPUSP, 1999.

AUSUBEL, D. P. A aprendizagem significativa: a teoria de David Ausubel. São Paulo: Moraes, 1982.

BAUMAN, Z. Medo líquido. Tradução Carlos Alberto Medeiros. Rio de Janeiro: Zahar, 2008.

BEZERRA, E.; DIMENSTIEN, M. O CAPS e o trabalho em rede: tecendo apoio matricial na atenção básica. Psicologia: Ciência e Profissão, Brasília, DF, v. 28, n. 3, p. 632-645, 2008. Quadrimestral. 
BRASIL. Ministério da Saúde. Secretaria de Gestão do Trabalho e da Educação na Saúde. Portaria n. ${ }^{0}$ 198, de 13 de fevereiro de 2004. Institui a Política Nacional de Educação Permanente em Saúde como estratégia do Sistema Único de Saúde para a formação e o desenvolvimento de trabalhadores para o setor e dá outras providências. Diário Oficial [da República Federativa do Brasil], Brasília, n. 32, 16 fev. 2004 Seção I, p... Disponível em: <http://dtr2001.saude.gov.br/sas/PORTARIAS/ Port2004/GM/GM-198.htm>. Acesso em: 17 maio 2011.

. Secretaria de Atenção à Saúde. DAPE. Coordenação Geral de Saúde Mental. Reforma psiquiátrica e política de saúde mental no Brasil. Documento apresentado à Conferência Regional de Reforma dos Serviços de Saúde Mental: 15 anos depois de Caracas. OPAS. Brasília, DF: Ministério da Educação, 2005.

Secretaria de Gestão do Trabalho e da Educação na Saúde. Departamento de Gestão da Educação em Saúde. Política Nacional de Educação Permanente em Saúde. Brasília, DF: Ministério da Saúde, 2009.

CECCIM, R. B. Educação permanente em saúde: desafio ambicioso e necessário. Interface - Comunicão, Saúde, Educação, Botucatu, v. 9, n. 16, p. 161-177, set. 2004-fev. 2005.

FERREIRA, V. S. C. et al. Processo de trabalho do agente comunitário de saúde e a reestruturação produtiva. Caderno de Saúde Pública, Rio de Janeiro, v. 25, n. 4, p. 898-906, abr. 2009.

FREIRE, P. Ação cultural para a liberdade e outros escritos. Rio de Janeiro: Paz e Terra, 1982. 
FREIRE, P. Pedagogia da autonomia: saberes necessários à prática educativa. São Paulo: Paz e Terra, 1996.

\section{GRUPO 1. Projeto Construção Social da Aprendiza-} gem acerca da Saúde Mental e Saúde da Família: grupo de discussão [maio 2008]. Moderadores: Rozemere Cardoso de Souza e Erika Antunes Vasconcellos. Jequié: Uesc: Fapesb, 2009, gravador digital. p. 1-21.Grupo de discussão produtor sobre a inserção da saúde mental na Estratégia de Saúde da Família.

\section{GRUPO 2. Projeto Construção Social da Aprendiza-} gem acerca da Saúde Mental e Saúde da Família: grupo de discussão [ago. 2008]. Moderadores: Rozemere Cardoso de Souza e Erika Antunes Vasconcellos. Ilhéus: Uesc: Fapesb, 2009, gravador digital. p. 1-20.Grupo de discussão produtor sobre a inserção da saúde mental na Estratégia de Saúde da Família.

\section{GRUPO 3. Projeto Construção Social da Aprendi-} zagem acerca da Saúde Mental e Saúde da Família: grupo de discussão [abr. 2008]. Moderadores: Rozemere Cardoso de Souza e Erika Antunes Vasconcellos. Vitória da Conquista: Uesc: Fapesb, 2009, gravador digital. p. 1-15.Grupo de discussão produtor sobre a inserção da saúde mental na Estratégia de Saúde da Família.

\section{GRUPO 4. Projeto Construção Social da Aprendiza-} gem acerca da Saúde Mental e Saúde da Família: grupo de discussão [maio 2008]. Moderadores: Josenaide Engracia dos Santos. Feira de Santana: Uesc: Fapesb, 2009, gravador digital. p. 1-13.Grupo de discussão produtor sobre a inserção da saúde mental na Estratégia de Saúde da Família. 
GRUPO 5. Projeto Construção Social da Aprendizagem acerca da Saúde Mental e Saúde da Família: grupo de discussão [maio 2009]. Moderadores: Josenaide Engracia dos Santos. Salvador: Uesc: Fapesb, 2009, gravador digital. p. 1-11.Grupo de discussão produtor sobre a inserção da saúde mental na Estratégia de Saúde da Família.

GRUPO 6. Projeto Construção Social da Aprendizagem acerca da Saúde Mental e Saúde da Família: grupo de discussão [novembro 2008]. Moderadores: Josenaide Engracia dos Santos. Salvador: Uesc: Fapesb, 2009, gravador digital. p. 1-10. Grupo de discussão produtor sobre a inserção da saúde mental na Estratégia de Saúde da Família.

GERGEN, K. J. O movimento do construcionismo social na psicologia moderna. Revista Internacional Interdisciplinar INTERthesis, Florianópolis, v. 6, n. 1, p. 299-325, 2009. Semestral.

GOMES, V. G. Apoio matricial: estratégia de interlocução na rede de saúde de Campinas/SP. Universidade Estadual de Campinas, 2006. (mimeografado).

MERHY, E. E. O desafio que a educação permanente tem em si: a pedagogia da implicação. Interface - Comunicação, Saúde, Educação, Botucatu, v. 9, n. 16, p. 172174, set. 2004-fev. 2005.

\section{PAIM, J. S. Desafios para a saúde coletiva no Século} XXI: atenção à saúde no Brasil. Salvador: EDUFBA, 2006.

PATTO, M. H. S. Formação profissional, compromisso político e luta antimanicomial. In: FERNANDES, M. I. A.; SCARCELLI, I. R.; COSTA, E. (org.). Fim de século: ainda manicômios? São Paulo: IPUSP, 1999. 


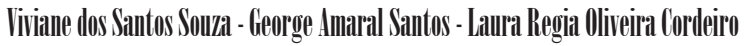

SANTOS, R. V. Abordagens do processo de ensino e aprendizagem. Revista Integração Ensino-Pesquisa-Extensão, São Paulo, ano 11, n. 40, p. 19-31, jan.-fev.-mar. 2005. 

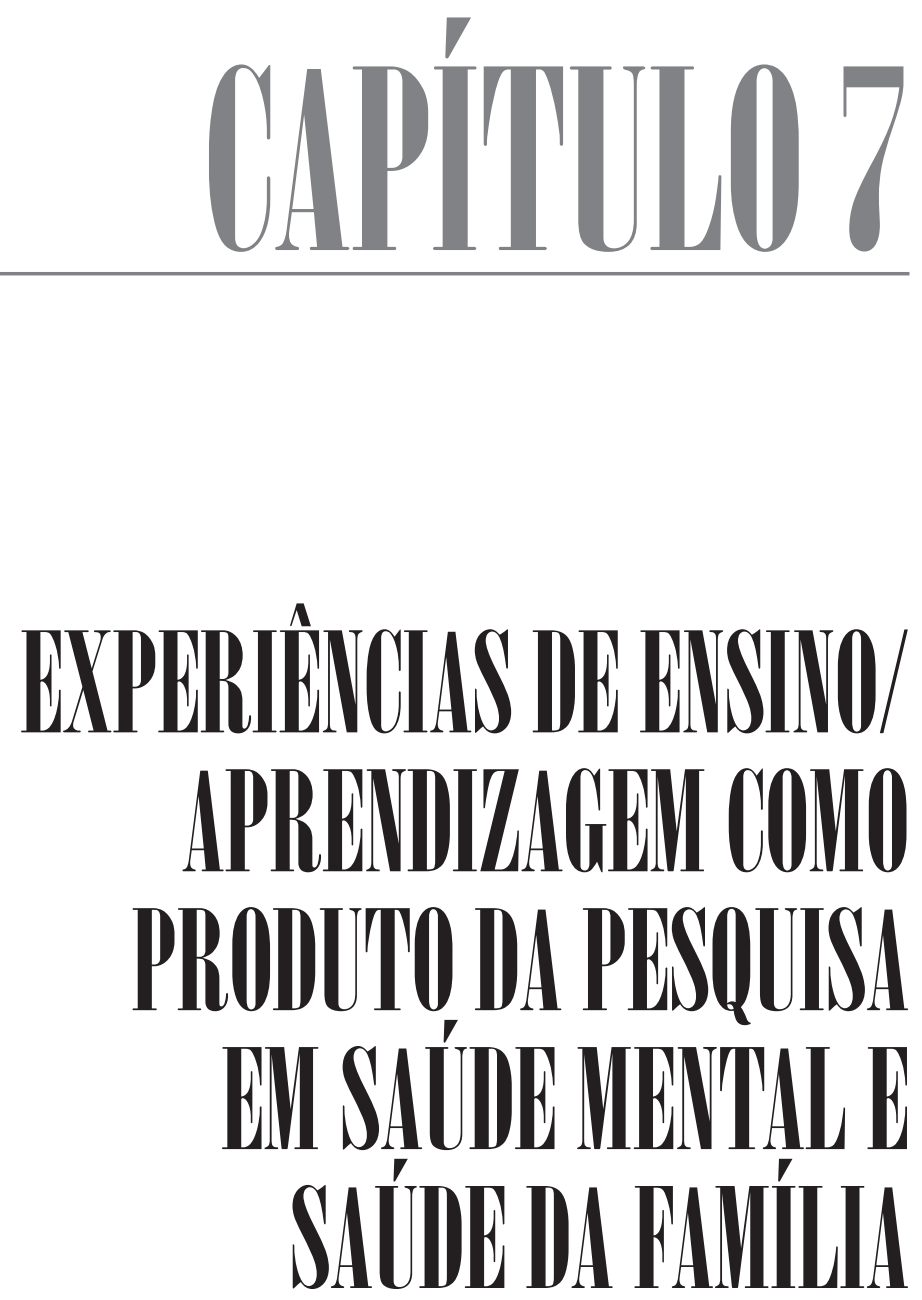

Rozemere Ciardaso de Sourzi Josentidide Engrieccia dos Sintos Vivitinne dos Sintos Soutzia Vairiten Morais Cialdass 
D

esquisar sobre a saúde mental e a Estratégia de Saúde da Família (ESF), a partir da escuta de pessoas com história de sofrimento psíquico e, especialmente, de equipes que atuam na Estratégia desde o princípio, produziu, nestes autores, inquietações impulsionadoras de atitudes proativas em direção ao ensino/aprendizagem em saúde mental, um processo visto a partir do compartilhamento de saberes e de práticas.

Em cada questão de pesquisa um convite, imediato, ao participante a refletir sobre a saúde mental, um ato da fala e, por que não dizer, de práticas sociais que se construíam a partir de vozes comuns a todas as equipes de saúde da família investigadas e, também, de vozes peculiares ao momento e cenário vividos por elas, na produção do cuidado. Embora com uma linguagem marcada pelo sofrimento psíquico das equipes, tanto em relação à população assistida quanto a si mesma, essa mesma linguagem produziu momentos de escuta, de descobertas de recursos e de construção de contratos, como pode ser visto ao longo desta obra.

Como resultado dessa trajetória, este capítulo enfatiza processos de ensino/aprendizagem envolvendo Equipes de Saúde da Família, além de estudantes em processo de formação e outros profissionais em serviço.

\section{As experiências de aprendizagem}

\section{A aprendizagem na Graduação}

A primeira experiência de ensino em saúde mental em território de abrangência da ESF ocorreu 
durante a disciplina Prática de Enfermagem Psiquiátrica da Universidade Estadual de Santa Cruz (Uesc), no ano de 2001, motivada pela pesquisa sobre qualidade de vida de pessoas egressas de instituições psiquiátricas. Essa vivência envolveu o uso de dispositivos como a visita domiciliar, a escuta terapêutica, as práticas de integração e lazer (caminhada pela praia), reunião de equipe e ações educativas em sala de espera e em outros espaços da comunidade como, por exemplo, as igrejas. As ações eram voltadas para toda a população adscrita da Unidade de Saúde da Família (USF), incluindo também as pessoas com transtornos mentais, assistidas no domicílio pelos estudantes em companhia de Agentes Comunitários de Saúde (ACS). Em uma das caminhadas, registrou-se a surpresa de um ACS, ao ver a participação de uma jovem que, até então, vivia apenas em um quarto de condições precárias e separado da estrutura da casa de seus familiares. Aos poucos, através da intervenção de estudantes e da própria equipe da ESF, a jovem ocupava os espaços internos e externos da casa, passando a ser vista pelos vizinhos. Além disso, ela passou a circular em outros espaços sociais, ampliando trocas na comunidade onde vivia.

Em cada contato ou visita domiciliar, nascia um novo olhar sobre a saúde mental e a desconstrução do medo relacionado à loucura referido pelos estudantes e pelos próprios agentes comunitários de saúde. Dessa experiência, abriram-se rodas para a compreensão a partir do contato e do convite a outros (secretaria de saúde, secretaria de assistência social, igrejas) a interferirem sobre o processo saúde/doença mental. 
O Projeto de Extensão Universitária Integrando a Saúde Mental e a Saúde da Família

O projeto foi criado no ano de 2005, na forma de ação permanente, e vincula-se ao Departamento de Ciências da Saúde da Uesc. Propõe-se a intervir sobre as demandas e as necessidades de saúde mental identificadas na população de abrangência da ESF, incluindo os trabalhadores de saúde como sujeitos. De caráter interdisciplinar, valoriza a participação e a produção de diálogos entre profissionais e estudantes da graduação de diferentes categorias, como Educação Física, Medicina, Fisioterapia, Psicologia, Pedagogia, Enfermagem e Biomedicina.

Dos dispositivos de aprendizagem utilizados no projeto, destacam-se: a formação de grupos de estudo acerca de temas em saúde mental, com encontros semanais e participação de, no máximo, 12 pessoas/grupo, a fim de favorecer a participação nas discussões coletivas; grupo de apoio para pessoas em sofrimento psíquico no território; visitas domiciliares para os casos considerados graves pelos agentes comunitários de saúde; grupo terapêutico para profissionais de uma equipe da ESF; ações de respeito à subjetividade dos trabalhadores no desenvolvimento das etapas do projeto.

Durante o intercâmbio entre as pessoas, tanto na ação de extensão quanto nas pesquisas associadas ao tema, temos visto que cada equipe, frente às condições de trabalho, aos riscos do cotidiano, e/ou ao enraizamento da cultura manicomial, tem tempos diferentes para a inserção do cuidado em saúde mental no território. Algumas equipes demandam ser cuidadas ou 
"preparadas" para depois cuidar, como um "solo" que precisa ser trabalhado para depois receber a "semente". Temos construído, nas diversas oportunidades de aproximações com as equipes, meios de suporte e a ideia de que esse processo de ser cuidado e "preparado" pode ocorrer simultaneamente à produção de cuidado às populações assistidas. Isso motiva a construção do saber e fazer como unidades, como se verá mais adiante neste trabalho.

A extensão desempenha, ainda, papel fundamental na formação de estudantes, envolvendo articulação com as ações de ensino e de pesquisa. Como se dá essa articulação? Em linhas gerais, toda ação de extensão ou o conjunto delas é produto de reflexão nos grupos de estudo e de produção de textos para divulgação científica. Além disso, a extensão faz suscitar questionamentos que motivam a elaboração e o desenvolvimento de novos projetos de pesquisa. Nesse contexto, a aprendizagem significativa é o cerne do ensino, pois as ações de extensão e de pesquisa, definidas em rodas que por si só já produzem ganhos de aprendizagem, abrem sempre possibilidades para convidar outros, a partir de ações educativas por meio do compartilhamento de saberes e práticas em saúde mental.

Assim, o projeto adota um método aberto, capaz de repensar e reorientar seus objetivos e ações, de modo contínuo e progressivo, com base nas relações e práticas sociais produzidas no cotidiano. Em função disso, a equipe responsável por ele tem recebido, com frequência, convites para palestras e cursos de extensão com profissionais da área, da ESF, do Núcleo de Apoio à Saúde da Família (Nasf) e comunidade em geral. 
Assim, o projeto segue seu curso aprendendo, ensinando e produzindo sentidos, também, acerca da ideia que Fagundes et al. (1992) propõe, quando afirma que todos os lugares têm música, todos os lugares têm artistas, todos os lugares têm onde se dança, têm onde as pessoas se reúnem e se faz necessário identificar e utilizar estes espaços como produtores de saúde e trabalhar nesta direção com as pessoas até então excluídas. $\mathrm{O}$ autor nos leva a refletir sobre as necessidades humanas, ao dizer que as pessoas precisam comer, dormir, ser cuidadas e bem tratadas e, nesse sentido, muito além de uma preocupação do setor de saúde, o atendimento a essas necessidades deve ser um comprometimento social.

Os fóruns de saúde mental nas periferias da capital e o Programa de Residência Multiprofissional em Saúde

Os residentes do Núcleo de Saúde Mental da Uneb promoveram cinco fóruns sobre a saúde mental, em Salvador, Bahia, em parceria com unidades básicas de saúde, conselhos locais de saúde, associação de moradores, polícia militar, Centros de Atenção Psicossocial e a Associação Metamorfose Ambulante de usuários e familiares do sistema de saúde mental do estado da Bahia (Amea-BA). Nesses fóruns foram abordados assuntos relacionados à economia solidária, à reforma da atenção psiquiátrica, ao uso de álcool e outras drogas, ao que fazer em relação à pessoa em sofrimento mental e ao papel da comunidade no contexto da reabilitação psicossocial dessas pessoas e na 
promoção da saúde mental. A criação desses fóruns foi uma estratégia dos residentes de saúde mental, em parceria com a comunidade, para a mobilização e o desenvolvimento social.

A Agência Nacional de Desenvolvimento Microempresarial (Ande) participou desses fóruns, junto com bancos comunitários, para colaborar de maneira efetiva na utilização das políticas públicas em benefício da comunidade com foco na promoção da saúde e na construção de comunidades saudáveis.

A equipe de residentes que conduziu os fóruns promovidos pelos residentes da Uneb foi composta por várias categorias profissionais: enfermeiros, psicólogos, terapeutas ocupacionais, fonoaudiólogos e assistentes sociais. A residência tem como campo de estágio e trabalho um Centro de Atenção Psicossocial em Álcool e outras Drogas (Caps ad) e um Centro de Atenção Psicossocial tipo II (Caps II), ambos localizados no município de Salvador.

Esses fóruns cumpriram sua função de educação como uma ação social intencional, através da qual se promoveram aprendizagens mobilizadoras de reflexão, problematização e construção de novas práticas relacionadas à saúde mental, bem como uma estratégia de participação popular no redirecionamento da vida social.

Os eventos científicos como espaços de ensino/ aprendizagem

Das pesquisas surgiu a parceria entre duas universidades públicas do estado da Bahia, a Uesc e a 
Uneb, para a realização de eventos científicos, os quais marcaram múltiplos aprendizados em saúde mental com ênfase na atenção básica. Dentre estes eventos destacam-se quatro: I e II Encontros de Saúde Mental da Uneb (2006 e 2007), o Encontro Norte Nordeste de Saúde Mental e Atenção Básica (2009) e o II Simpósio de Saúde Mental da Uesc (2010).

Um dos principais dispositivos de ensino/aprendizagem dos eventos foram as rodas de discussão temática, ora nomeadas de redes de experiências, ora de rodas de fuxico ${ }^{1}$, ambas com abordagem de um tema específico e com a presença de um ou mais convidados para a produção de diálogos entre os participantes. Nas rodas de fuxico, os assentos eram dispostos em círculo, contendo no centro pequenos cortes de tecidos, linhas e agulhas à disposição dos participantes para construírem "fuxicos" e aproveitarem o exercício da arte, tomada como uma metáfora, para "costurarem", também, frases, ideias e sentimentos em relação ao tema. No mesmo período de tempo, com duas horas de duração no máximo, coexistiam rodas, com uma variedade de temas, de livre escolha dos participantes do evento.

${ }^{1}$ É um tipo de costura artesanal, tecida através de retalhos em formato de pequenos círculos, que unidos um ao outro dão forma a diferentes objetos de uso, como: toalhas, colchas, roupas, bolsas, almofadas, cortinas, flores, quadros, acessórios femininos, bonecas, enfim, o que mais a criatividade permitir. O nome originou-se no nordeste do Brasil, entre mulheres que se reuniam para costurar e aproveitavam para trocar ideias, fofocar, mexericar... fazer fuxicos (N. A.). 
Um dos eventos contou com o apoio da Fundação de Amparo à Pesquisa do Estado da Bahia, que funcionou como facilitador para a participação de pesquisadores e profissionais de outros Estados do país, fomentando ainda mais o debate acerca do tema: "Diversidade de olhares sobre a saúde mental". Ter o "olhar como um dispositivo" foi o convite feito pela conferencista Cláudia Tallemberg, do Rio de Janeiro. Refletindo sobre esse olhar, Luís Fernando Tófoli, do Ceará, lembrou-nos a metáfora da lagarta, seu processo de metamorfose e sua transformação em lindas borboletas para pensar o processo de mudança na atenção à saúde mental. Segundo Tófoli (2010), a princípio, a saúde mental lembra uma lagarta, feia, que produz "nojo", algo do qual não queremos aproximação e que pode representar uma ameaça, mas, ao passar por transformações, pode-se ver com o tempo (a metamorfose leva tempo) a beleza da borboleta, representada na saúde mental, através da liberdade de ser, da descoberta de potencialidades, dos recursos, do desenvolvimento de sujeitos, das aproximações, da ampliação de trocas sociais.

Ressaltam-se ainda outros aspectos formativos dos eventos realizados: a aprendizagem sobre o uso de tecnologias leves, dentre elas, o acolhimento e a escuta terapêutica. Exemplo disso foi a experiência de um participante, que referiu motivação para sair, de bicicleta, à escuta dos usuários em suas casas, aos finais de semana. A participação em eventos científicos mostra-se como um potencial para inovação das práticas assistenciais - impacto comumente esperado por seus idealizadores. 


\section{O Curso Introdutório em Saúde Mental}

Trata-se de um curso de extensão de curta duração (6oh), que foi destinado aos profissionais do Centro de Atenção Psicossocial (Caps) e das equipes da ESF dos municípios de Ilhéus (2008) e Itororó (2010), Bahia, e teve a peculiaridade de contar com a participação de estudantes de graduação dos cursos de Enfermagem, Medicina e Pedagogia como ministrantes. Para tanto, os discentes passaram o período de um semestre letivo preparando-se, através de grupos de estudos, para o uso de metodologias participativas de ensino/aprendizagem, dentre elas: o método da roda, de Campos (2000); a pedagogia da autonomia, de Freire (1996); a abordagem construcionista social, com ênfase nas práticas discursivas e produção de sentidos no cotidiano, de Spink (1999).

Os conteúdos dos cursos foram temas sugeridos por Equipes de Saúde da Família e pela equipe de docentes e estudantes do Projeto de Extensão Universitária Integrando Saúde Mental e Saúde da Família. O método da roda foi aplicado em todo o processo de construção do curso, desde a identificação das demandas por conhecimentos em saúde mental, indicadas pelas equipes da ESF, bem como dos recursos para a aprendizagem. Dos conteúdos abordados, destacamos: as concepções de saúde/adoecimento mental e cuidado, a pessoa com depressão e transtorno de ansiedade, a família, a saúde mental e a escuta terapêutica, as redes e os recursos sociais de apoio à saúde mental, o uso de álcool e outras drogas, a autoestima e o cuidado do trabalhador de saúde. 
Assim, as aulas foram construídas utilizando-se estratégias participativas de ensino, com vistas a incentivar os atores envolvidos para a construção coletiva de conhecimento. Quanto aos dispositivos de ensino/aprendizagem, cabe salientar: o uso de músicas, com discussão de letras associadas aos sintomas de tristeza, depressão e ansiedade; vídeos com experiências inovadoras em saúde mental; produção de peças de curta duração sobre as experiências de saúde mental no cotidiano; construção de mapas falantes; utilização de técnicas participativas de aprendizagem; momentos de integração e exercícios grupais.

\section{O Curso de Especialização em Saúde Mental}

Implantado no ano de 2005, o curso de Especialização em Saúde Mental da Uesc foi outra experiência de ensino/aprendizagem extremamente valiosa. Com carga horária de 420 horas, teve caráter multidisciplinar e o comprometimento com o cuidado em saúde mental de base comunitária. Nos trabalhos de conclusão de curso (TCC), desenvolvidos na forma de artigo científico, motivou-se a problematização em saúde mental a partir do lugar que o profissional ocupava no seu cotidiano: escolas, hospitais gerais, Unidades Básicas de Saúde, Estratégia de Saúde da Família, Núcleo de Apoio à Saúde da Família (Nasf), Caps e outros serviços substitutivos, Centros de Referência em Assistência Social (Cras), Instituições de Ensino Superior, comunicação social, gestão, polícia militar, projetos sociais etc. Disso resultaram trabalhos diversos e o despertar de alguns profissionais para a atividade de pesquisa. 
O curso formou duas turmas e foi interrompido por falta de recursos para sua continuidade, situação que tem motivado a busca por parcerias com o governo estadual e/ou federal a fim de se retomar essa importante ação educativa. Ressalta-se que a coordenação do curso recebe frequentes solicitações para abertura de novas turmas, principalmente advindas de profissionais que atuam em serviços de saúde mental e concluintes de cursos de graduação, o que indica uma grande demanda por qualificação na área.

\section{O apoio matricial a pedido de uma equipe de saúde da família}

O apoio matricial pode ser entendido como estratégia de cuidado singularizado, na qual é possível atuar na complexidade da vida dos sujeitos, afirmando-se como atuação no campo existencial, onde as relações de afeto, cooperação e produção de saúde mental se intensificam. Além disso, o apoio matricial implica sempre a construção de um projeto terapêutico integrado, entre equipe de saúde da família e apoiadores. Com o intuito de efetivar essa estratégia, o Centro de Atenção Psicossocial Álcool e outras Drogas (Caps ad) e o Núcleo de Saúde Mental do Programa de Residência Multiprofissional em Saúde da Universidade do Estado da Bahia (Uneb) realizaram o matriciamento em uma das equipes de saúde da família.

A aproximação com a Equipe de Saúde da Família ocorreu através da participação em um grupo focal, proveniente do projeto de pesquisa fruto da parceria entre a Uesc e a Uneb, financiado pela Fundação de 
Amparo à Pesquisa do Estado da Bahia (Fapesb). O referido grupo objetivou suscitar discussões acerca da saúde mental e contou com a participação da preceptora-pesquisadora, responsável pela condução, uma representante das residentes, que registrou o encontro, e sete integrantes da equipe.

O grupo focal favoreceu a percepção de um elemento novo: a possibilidade de produzirmos conhecimento, a partir de experiências concretas no cotidiano, objetivando contribuir com o processo de trabalho da equipe, no que se refere às ações de saúde mental. Nesse sentido, a finalidade era pisar no mesmo solo que a equipe, ouvi-la e registrar suas demandas para concretizar o apoio matricial.

A condução do apoio matricial foi realizada pelas residentes com formação em Enfermagem, Psicologia, Serviço Social e Terapia Ocupacional, juntamente com uma técnica do Caps ad. O envolvimento de várias categorias profissionais objetivou atender ao princípio da integralidade, de modo que os trabalhos atuassem na produção de cuidado de forma solidária e interdisciplinar. Conforme Ayres (2004), cuidado é uma interação entre dois ou mais sujeitos, visando o alívio de um sofrimento ou o alcance de um bem-estar, sempre mediado por saberes, especificamente, voltados para essa finalidade.

Além disso, segundo Figueiredo (2006), a tarefa de apoio matricial deve ser realizada por alguém especializado, que ofereça suporte para os profissionais lidarem com os sujeitos em sua totalidade, absorvendo as dimensões subjetivas e sociais do ser humano. Para a autora, o matriciamento em saúde mental traduz-se 
como suporte técnico especializado, em que conhecimentos e ações, historicamente reconhecidos como inerentes à área 'psi', são compartilhados com os demais profissionais de saúde. É um encontro, um espaço de troca de saberes, invenções e experimentações que auxiliem a equipe a ampliar sua clínica e sua escuta e a lidar com a subjetividade dos usuários.

As atividades foram desenvolvidas na área adscrita de uma Unidade de Saúde da Família (USF) de um bairro de Salvador. O bairro caracteriza-se como área de baixo nível socioeconômico, de difícil acesso, com alto índice de violência, sendo a USF o único serviço de saúde.

Havia um pedido intenso por cuidado da equipe da USF, e não por capacitações a que rotineiramente estava submetida. Entendemos, nesse momento, que os encontros - para fins de apoio matricial - além de abordagem aos conteúdos teórico-práticos, deveriam ser afetivos, em espaços genuinamente intersubjetivos. Ou seja, constatamos que mais importante que o planejamento da ação educativa, era como nós e a equipe interagiríamos, fato que determinou, inclusive, a concretização dessas vivências, nos encontros subsequentes com essa equipe. Sobre isto, Moura (2007) nos lembra que o encontro precede à técnica e é o que lhe dá consistência existencial, logo acreditamos que possui potencial para o agenciamento de desejos.

Houve surpresa, inicialmente, quando ouvimos da equipe uma solicitação teórica relacionada à saúde mental. Faziam referências a modelos tradicionais de capacitação, corroborando a ideia de educação bancária de Freire (2003), segundo a qual o 
indivíduo recebe os conhecimentos-conteúdos-acumulados pelo sujeito que sabe e que apenas os transfere, deformando, assim, a necessária criatividade do educando e do educador. Ao longo do processo, entendemos que o solicitado pela equipe foi apenas a reprodução do único modelo que conheciam como possibilidade de encontro entre o saber especializado e a saúde da família. Contudo, consideramos que seria interessante concretizarmos as ações a partir do que Carvalho, Acioli e Stotz (2001) preceituam como construção compartilhada - a experiência cotidiana da equipe de saúde da família.

O passo seguinte foi o levantamento dos temas de interesse da equipe. Foram apontados como prioritários: a identificação dos transtornos, formas de abordar o sujeito em crise e serviços que compõem a rede de atenção à saúde mental. Para isso, indicaram como metodologia principal a exposição teórica, ressaltando ainda a necessidade da presença dos apoiadores nas visitas domiciliares. Propusemos, também, a discussão dos casos como uma das metodologias do matriciamento, objetivando possibilitar significado vivencial aos conceitos. Após ajuste de demandas, acordamos que os encontros seriam realizados semanalmente, com momentos de discussão de casos e visitas domiciliares.

A formulação de estratégias para a realização do matriciamento se deu a partir do compartilhamento de ideias, o que permitiu a coleta e a análise de informações que, segundo Campos e Domitti (2007), favorecem a tomada de decisões e desencadeiam ações práticas. Com as informações, construímos um projeto que 
balizou a nossa prática e, em seguida, elaboramos um cronograma no qual prevíamos encontros semanais durante quatro meses, tempo julgado necessário para o estabelecimento do vínculo e da produção de cuidado junto à equipe.

O primeiro encontro foi destinado ao estabelecimento do vínculo, visando conhecer a história de cada um dos profissionais, as motivações, os desejos e as dificuldades relacionadas ao trabalho. Para isso, iniciamos o encontro com uma dinâmica de apresentação em que cada participante falava livremente sobre si, o motivo de sua escolha profissional e de sua atuação na ESF. Na semana seguinte, concretizando o segundo encontro, houve a apresentação do projeto construído pelos apoiadores, seguida de um momento para os grupos refletirem e negociarem os objetivos e ações previstas.

Apostamos em metodologias participativas, cujo conhecimento construído foi fruto da reflexão crítica da equipe, a partir das experiências prévias. O apoio matricial realizou-se mediante a combinação de encontros periódicos e regulares em três momentos: 1 . discussões teórico-práticas; 2. discussão coletiva dos casos; 3. aplicação no cotidiano dos conhecimentos compartilhados. Vale ressaltar que tais etapas aconteceram, em certos momentos, de forma paralela, servindo a divisão apenas para garantir uma organização metodológica.

As discussões teórico-práticas configuraram uma construção coletiva de saberes e de práticas que instrumentalizaram ações da equipe através de núcleos temáticos, os quais são objetos de reflexão capazes 
de produzir conhecimento sobre intervenção. Entre os temas abordados, estava a história da loucura; a reforma psiquiátrica; o entendimento sobre a crise; a identificação/diferenciação de transtornos, deficiências, dependências; o uso de álcool e outras drogas; a rede de serviços, território e saúde mental na atenção básica. Os temas foram trabalhados a partir de histórias, dúvidas e falas dos profissionais. Utilizamos em todos os encontros vídeos que estimularam as discussões dos temas.

Paralelo a essas discussões, os casos eram problematizados em conjunto. Nesses encontros, foram trazidos fundamentos teóricos, ao mesmo tempo em que se procurou elaborar projetos terapêuticos e acordar linhas de intervenção para os vários profissionais envolvidos. Para os casos imprevistos e urgentes, em que não seria recomendável aguardar a reunião regular, os apoiadores eram acionados pelos agentes comunitários de saúde.

Ainda nos primeiros encontros com a equipe, distribuímos para os ACS uma ficha padrão de identificação de sofrimento psíquico na comunidade. Entre os problemas reconhecidos, o uso abusivo de álcool e de outras drogas foi o mais prevalente, tendo proeminência os casos de alcoolismo e de depressão menor e outros transtornos que não sabiam especificar. Para operacionalização das visitas, dois apoiadores acompanhavam os ACS. As visitas demonstraram que os agentes utilizavam estratégias para lidar com os casos que atendiam, ainda que desconhecessem a rede formal de serviços em saúde mental e as propostas de cuidado psicossocial. Não se pode esquecer, como afirma 
Coulon (1995), que os atores interpretam constantemente a realidade social e inventam a vida em uma permanente bricolagem. Aproveitávamos, portanto, essas situações para levar informação às famílias e possibilitar novas estratégias de cuidado, instrumentalizando não só os familiares, mas também o ACS.

A nova estratégia possibilitou maior resolutividade dos casos identificados pelos ACS, pensando na perspectiva do cuidado integral, além do fortalecimento do vínculo entre todos os sujeitos envolvidos no processo. Houve, assim, maior envolvimento com a proposta do matriciamento, devido, especialmente, a uma correlação com o universo biográfico dos ACS, corroborando a ideia de que a estratégia de interação entre os vários sujeitos é aspecto relevante na produção de cuidado. Gadamer (1991) ensina que é a partir de um tipo de saber que não cria objetos, mas constitui sujeitos diante dos objetos criados no mundo e para seu mundo, que se pode garantir um conhecimento genuíno.

A equipe passou a perceber que o investimento humano é fundamental para se estabelecer vínculo com o sujeito. Vale ressaltar que os ACS não dimensionavam o vínculo já estabelecido com os usuários atendidos por eles, entretanto foi este vínculo que possibilitou nossa entrada em seus domicílios. Além disso, no decorrer do processo, a equipe passou a se dar conta de que já exercia o cuidado em saúde mental, mesmo antes do matriciamento.

A equipe passou a perceber que os encontros produziam cuidado para a saúde mental dela mesma e seus integrantes começaram a trazer histórias 
de suas próprias vidas, de familiares e de vizinhos mais próximos. Conforme Rabelo (1999), narrando os eventos vividos, os indivíduos criam um campo para ação coletiva: os eventos, tal qual narrados, postulam certas identidades e impelem atores participantes da situação e da fala a tomar posições condizentes com o estado de coisas apresentado em suas próprias histórias.

No decorrer do matriciamento, percebemos que os ACS adquiriram segurança progressiva no que se refere às suas intervenções durante as visitas. Pontuaram aspectos pertinentes ao cuidado em saúde mental, tendo em vista que eles eram os que mais sabiam sobre as histórias de vida dos sujeitos. Isso garantiu que o cuidado, agora mais qualificado, fosse mantido independente da nossa presença.

É possível afirmar, também, que os ACS passaram a entrever a importância de cuidar de toda a família que convive com o sofrimento psíquico. Ao longo de todo processo construído, percebemos que a formação do vínculo, a circulação de afetos, a co-construção do conhecimento e a produção de cuidado com a equipe e com os usuários foram possíveis pela existência de conexões interativas entre os apoiadores, a equipe e os usuários. Nesse sentido, as ações surgiram das redes que interagiram e influenciaram-se mutuamente, acrescidas da disponibilidade de não reduzir a experiência da equipe a resultados de fatores causais.

Em todas essas experiências, uma ideia fortemente construída e exercitada foi a do ensino/aprendizagem enquanto processo de compartilhamento de saberes e de práticas sociais, que passamos a descrever. 


\section{Ensino aprendizagem em saúde mental como processo de compartilhamento de saberes e de práticas}

A construção compartilhada de conhecimento é uma metodologia desenvolvida na prática da educação e saúde que considera a experiência cotidiana dos indivíduos envolvidos e tem por finalidade a conquista, pelos vários atores, de maior poder de intervenção nas relações sociais que influenciam a qualidade de suas vidas e da saúde (CARVALHO; ACIOLI; STOTZ, 2001).

Compartilhar significa "ter ou tomar parte em, participar de; compartir" (FERREIRA, 1985), partilhar com alguém (PRIBERAM, 2010), que traz o sentido de com o outro, ao invés de para o outro. Portanto foge da pedagogia tradicional de transmissão do conhecimento, que foca o ensino na figura de um expert, sendo o outro o sujeito/objeto do saber produzido. Compartilhar abre possibilidades de interação, de ter o ensino/aprendizagem como um processo que se realiza com o outro, a partir de uma relação de partilha, de participação; portanto docentes e estudantes constituem-se em sujeitos ativos de seu próprio aprendizado. Nessa relação, tanto o docente quanto os estudantes são detentores de conhecimentos que, através do compartilhamento, fazem emergir uma diversidade de saberes e de práticas sociais. Valoriza a polifonia diversas vozes - e a polissemia - os múltiplos sentidos que envolvem saber e fazer.

Compartilhar, portanto, implica desenvolver relações de intercâmbio entre pessoas, ganhos de conhecimentos vistos em sua pluralidade, construção de 
cumplicidade, cooperação, corresponsabilidade, solidariedade, constituição de sujeitos e de coletivos organizados, partilha de poder.

O campo da atenção psicossocial requer iniciativas específicas para compartilhamento de conhecimentos, voltadas para a Estratégia de Saúde da Família. Nesse contexto, espera-se o primeiro contato de indivíduos, famílias e comunidade com o Sistema Único de Saúde.

O ensino/aprendizagem também se sustenta no princípio da integralidade do SUS, compreendido como articulações de promoção da saúde, prevenção e reabilitação, integrado com outros setores, espaços socioculturais e práticas não institucionalizadas da produção de cuidado existentes nos diversos territórios.

Sobre saúde mental, o compartilhamento motiva-nos a questionar: a que se referem as expressões saberes e práticas? E o termo saúde mental? Existe prática sem saber? E o inverso? Como funciona a frase "a teoria está longe da prática", e de que forma ela afeta o cotidiano das práticas de saúde mental? Dizer e fazer podem ser unidades inseparáveis?

Esses questionamentos vêm da constatação de que, quando separamos dizer e fazer, ou seja, teoria e prática, saberes e práticas, estabelecemos uma distinção, com a possibilidade de tornar a teoria uma utopia ou de um valor superestimado sobre os saberes produzidos das experiências do cotidiano. $\mathrm{Na}$ primeira hipótese, trata-se de ter determinados saberes e/ou teorias como algo inalcançável, inatingível, de tal modo que perdemos de ver e versar sobre as práticas que estão implícitas nelas. E, diante da 
impossibilidade, deixamos também de considerar os modos de construí-los ou compartilhá-los no cotidiano. Outra implicação dessas ideias está no imobilismo ou desvalorização frente às oportunidades de produção de conhecimento, uma vez que ele não refletiria o cotidiano ou não teria o que contribuir para o cotidiano profissional.

A segunda hipótese, a de ter determinados conhecimentos como de um valor superestimado sobre outros, inclusive, aqueles que são produzidos no cotidiano, implica em o sujeito responsável pelo compartilhamento adotar postura de expert do assunto, sendo os demais sujeitos "sem conhecimento", os quais serão depositários do que se pretende tornar conhecido. A nosso ver, ambas as hipóteses prejudicam o repartir e impedem o diálogo capaz de reconhecer os saberes e as práticas em sua pluralidade e ganhos no cotidiano.

Em nossas experiências de partilhar o conhecimento em saúde mental, dizer e fazer foram pensados como unidades inseparáveis. Tal compreensão convida-nos a refletir sobre o que é produzido na linguagem em uso no cotidiano e sobre as implicações sociais da mesma em relação ao que se pretende construir. Nossas ideias e posicionamentos têm nos ajudado ou impedido a caminhar em meio a situações adversas? E se tem impedido, que outras noções podem mudar a orientação desse posicionamento ou o próprio posicionamento?

Além disso, compartilhar tem um fim, um propósito, e convida a um contexto de compartilhamento. Nossas experiências focaram propósitos 
de compartilhamento sobre os seguintes processos: reforma da atenção psiquiátrica e dos serviços substitutivos, com discussão sobre os princípios do modelo manicomial a serem desconstruídos e os novos princípios que precisavam ser construídos, dentre eles, a inclusão da saúde mental no Sistema Único de Saúde, o uso dos recursos da comunidade para essa área, a interdisciplinaridade e intersetorialidade da atenção à saúde, a possibilidade de viver sem manicômios no ensino, nos serviços e na sociedade em geral.

Nesse sentido, todos os espaços sociais são lugares em potencial para a construção de oportunidades de divisão de saberes e práticas: a casa, a escola, a praça, os meios de comunicação, as conversas do dia a dia, sempre ricas em produção de sentidos.

Sobre os fatores que influenciam o compartilhamento de saberes e práticas, Alcará et al. (2009) destacam quatro aspectos: a natureza do compartilhamento, isto é, a definição do que se pretende compartilhar, qual é o conhecimento; a motivação para compartilhar, destacando a importância no compartilhamento desse conhecimento; as oportunidades de compartilhamento, referindo-se à invenção de espaços para produção do compartilhamento; e a cultura do ambiente de trabalho.

Todos esses aspectos, entendidos como processos, fazem mover ações em direção a um posicionamento contínuo e progressivo de compartilhamento e de clareza quanto ao conhecimento.

Dos fatores que dificultam o compartilhamento de saberes, destacam-se: arrogância epistemológica, 
atitude de tudo saber, de não ter o que aprender, medos, gestão linear e centralizadora, nomeações ligadas a déficit - rótulos, uniformidade na assistência, explicações padronizadas para os problemas, foco nas faltas.

Frente às dificuldades, nasce a responsabilidade de rever os espaços e reorientar estratégias para compartilhamento, a fim de romper com o instituído e ter uma construção instituinte de algo inovador. Nisto, mais uma vez, o cotidiano pode estender os espaços de ação e de interação a serem valorizados.

\section{O cotidiano como ponto de partida do compartilhamento}

O compartilhamento considera a experiência diária dos indivíduos envolvidos como uma conquista de atores sociais com maior poder de intervenção nas relações sociais e que influencia na qualidade de vida e, principalmente, na saúde (CARVALHO; ACIOLI; STOTZ, 2001).

Nesse sentido, o dia a dia é cenário rico de produção de sentidos e de práticas sociais dinâmicas, as quais podem ser modificadas a partir dos diálogos produzidos. Toda experiência, situação nova, por exemplo, convida o outro a um posicionamento e possível reflexão geradora de mudanças.

Ao oferecer oportunidades de compartilhamento do conhecimento produzido da e na experiência de todos os dias, ele precisa se entrelaçar com outros saberes e ser analisado com vistas às implicações sociais para determinadas populações. Isso refletirá a importância de cada saber/fazer e indicará formas de 
compartilhar, a partir dessa construção. Possibilita, também, ao docente ou apoiador matricial uma aproximação com o outro e a descoberta do que existe de recursos de aprendizagem, assim como de necessidades de repartir.

Ter a dialogia como dispositivo desse processo é reconhecer todas as conversas do cotidiano como produtoras de sentidos e de práticas sociais. É reconhecer o valor de cada sujeito no processo de aprendizagem e saber que mesmo aqueles que dizem "não saber" são possuidores de saberes e posicionamentos sociais.

O cotidiano como ponto de partida aproxima também o sentido da chegada do apoiador em cenários novos; por isso evita o posicionamento de tudo saber, o que implica na ideia de que não há mais o que aprender apenas o que ensinar; é quando se generalizam as equipes e os cotidianos, sem ao menos escutá-las ou dirigir-lhes o olhar.

\section{A postura do não saber e o que ela significa na produção do aprendizado em saúde mental}

Essa postura advém do construcionismo social e se aplica ao processo de compartilhamento de conhecimento, quando o docente ou apoiador instrumental a adota para exercer uma relação livre de ideias préconcebidas, para escutar o outro sem juízo de valor e ter uma atitude respeitosa quanto aos conhecimentos adotados nos diálogos.

Na construção do processo de ensino/aprendizagem em saúde mental, assumir essa postura significa 
que os profissionais e educadores possam reconhecerse como tendo um saber "de caráter provisório, que deve ser desafiado por outros saberes, inclusive, o do cliente, o único especialista na sua própria experiência” (GRANDESSO, 2000, p. 280).

\section{Tendências do ensino/aprendizagem em saúde mental e saúde da família: o pró-saúde/pet-saúde e o CRR}

Por meio de investimentos do Governo Federal em projetos de ensino/aprendizagem em saúde e a partir de um esforço conjunto entre os ministérios da Saúde e da Educação para o enfrentamento do crack e outras drogas, inserimo-nos em mais dois projetos de compartilhamento de saberes e de práticas em saúde mental, nomeados aqui de dispositivos institucionais de ensino/aprendizagem, são eles: o Programa Nacional de Reorientação da Formação Profissional em Saúde; o Programa de Educação pelo Trabalho para a Saúde; e o Centro Regional de Referência para Formação Permanente para o Enfrentamento do Crack, Álcool e Outras Drogas (CRR).

A partir dos projetos, espera-se conseguir o fortalecimento de parcerias entre as universidades, os serviços substitutivos e as Estratégias de Saúde da Família, para o ensino/aprendizagem em saúde mental, crack e outras drogas.

As expectativas são grandes em relação aos avanços advindos das experiências de ensino/aprendizagem na área, com impactos na produção e gestão do cuidado em saúde. Assim, acreditamos na ideia de que sempre é 
possível fazer alguma coisa a mais, se existe uma comunidade dotada de atribuições, competências, com uma estratégia de mudança do velho e comprometida com a construção do novo (EVARISTO, 2000).

\section{Incorporação de metáforas transformadoras da realidade: um último dispositivo de compartilhamento}

Devemos o aprendizado e uso desse dispositivo ao colega Samuel Macedo Guimarães, Terapeuta Corporal, que compartilha conosco momentos de ensino/ aprendizagem e nos fez olhar a importância da metáfora para o processo de aprendizagem.

Metáfora é a figura de linguagem em que um termo substitui outro em vista de uma relação de semelhança entre os elementos que os termos designam. Segundo Michaelis (2010, p. 1), trata-se do "emprego de uma palavra em sentido diferente do próprio por analogia ou semelhança”.

Quando empregamos a ideia de incorporar metáforas transformadoras da realidade, estamos convidados a pensar a(s) realidade(s) a partir de imagens, objetivo que nos leve a assumir posicionamentos em direção a mudanças, ao invés de uma atitude de passividade, a posicionamentos de movimentos. Ou seja, uma atitude de ruptura ao invés de permanência do habitual, caso o habitual já não satisfaça às necessidades e ideais, ou já não acrescente algo novo ao que já está em construção e pede por avanços.

A seguir, relatamos algumas metáforas que têm nos ajudado a ensinar e aprender na área, articulando 
pesquisa, ensino e extensão universitária. As metáforas do terremoto, do movimento da serpente e do jogo, propostas por Pearce (1996), para pensar o novo paradigma e a revolução das comunicações são extremamente úteis para pensar/fazer o apoio matricial em saúde mental, assim como outros processos de aprendizagem da área com enfoque na ESF, vejamos.

O terremoto é a primeira metáfora proposta pelo autor e traduz a imagem de estarmos diante de uma situação que nos causa "estranheza", "desorientação" ou parece-nos tão destrutiva, a ponto de fazer surgir um sentimento e posicionamento de "não há o que fazer”. O terremoto traz, também, a sensação de não saber em que se pode apoiar e sobre o que se pode ficar parado (PEARCE, 1996).

Construir o cuidado de saúde mental na ESF, um cenário aberto, ou seja, livre dos muros dos manicômios e livre de um espaço fechado ou considerado adequado para tal, como uma sala de consultório, parece produzir as mesmas angústias de estar no "terremoto". É tudo muito novo ou contrário à formação de muitos profissionais que tiveram suas vivências exclusivamente centradas no espaço dos grandes hospitais psiquiátricos, ou em especialistas da área "psi". Nesse último aspecto, se o cuidado é de especialista - ideia do modelo manicomial - aparece por si só a ideia de que só esse profissional detém conhecimento efetivo para intervir sobre os problemas na área da saúde mental. Se o cuidado agora é de responsabilidade da Equipe de Saúde da Família e de toda uma sociedade, isso também soa como um terremoto. Essas ideias trazem comumente as 
indagações feitas por profissionais de saúde da família em nossos contatos e rodas de aprendizagens desenvolvidas: O que fazer? Como fazer? Para onde encaminhar?

$\mathrm{Na}$ trajetória em busca de soluções diante de um "terremoto", Pearce (1996) propõe uma segunda metáfora, a de "um movimento de serpente", e afirma: "quem viu uma serpente deslizar pelo solo sabe que seu movimento tem algo de estranho, há certa sensualidade em sua maneira de deslocar-se, muito diferente de um animal bípede corrente" (p. 173). Comumente, nos identificamos mais com o animal bípede, porém as formas de comunicação de que participamos são mais bem entendidas se as concebermos como um movimento de serpente.

Semelhantemente, as novas formas de saber/fazer em saúde mental e os processos de aprendizagem relacionados serão mais bem compreendidos como um movimento de serpente. Esse movimento reflete as aproximações e negociações contínuas e necessárias ao contexto do território e deste com outros setores sociais. O deslocamento da serpente sobre o terreno é circular e contorna os obstáculos, de beleza e de sensualidade, a fim de envolver outros e ajudá-los a encontrar saídas para a situação.

Assim, temos aprendido e exercitado o princípio que o aprendizado de conhecimento requer um tempo diferente para cada equipe de saúde da família. E, fazendo uso de outra metáfora, a metáfora do "solo e da semente", alguns "solos" estão prontos para repartir, outros desgastados, precisam ser preparados para receber a semente, precisam de suporte. 
Em outros cenários, podemos ver equipes, no movimento que mais se assemelha ao bípede, correndo durante o terremoto. Quando imaginamos essa situação, pensamos que em pouco tempo, esse animal cairia e teria se machucado ao ponto de interromper o seu trajeto. Assim é quando desejamos o alcance de resultados imediatos do processo de aprendizagem e atropelamos o tempo de cada um, o que o outro tem a dizer e a fazer, de modo coletivo. Ensinamos, o que não significa mudanças no processo de trabalho dos profissionais de saúde da família. Cansados, por conta das demandas e necessidades pessoais, especialmente, pelo modo como desenvolvem o processo de trabalho - os resultados, a produtividade, os procedimentos - muitos deles não respondem à aprendizagem. Daí, o que foi partilhado poderá ser esquecido, ou as pessoas continuarão a reproduzir suas práticas, sem sentirem-se sujeitos de sua ação e, muito menos, sem a compreensão de que precisam (re) constituir-se no cuidado com o outro.

A terceira metáfora proposta por Pearce (1996) é a do jogo. O jogo, se tomado pela perspectiva do participante e não dos espectadores, tem algo a aprender e a ensinar. O jogo do qual fazemos parte é parte de nós, e a todo o momento coloca-nos diante de um novo desenho, de um novo processo de estruturação. Toda vez que jogamos, mudamos sua configuração, e os próximos eventos são pensados e estabelecidos por seus participantes. O jogo não fixa os eventos, sendo um processo que nunca cristaliza, porque os contextos vão se configurando permanentemente.

No ensino/aprendizagem em saúde mental, é fundamental a metáfora do jogo, ou seja, compreender que 
os eventos, os contextos e as pessoas são dinâmicos e que um movimento, de quem participa da construção social, muda a configuração e o destino do que parece cristalizado. Isto acontece especialmente quando consideramos a nós mesmos e ao outro como parte do jogo, desde o seu planejamento à execução de ações educativas.

Outras metáforas reforçam as ideias aqui explicitadas, porque nos ajudam a pensar e fazer movimentos de aproximações com o outro, no processo de aprendizagem. A metáfora da rede, definida por Pitta (2001, p. 19) como

sentido de juntar fios dispersos e articulá-los, como num tear, para lhes dar sentido, transformando-os em vestimentas, agasalhos protetores para enfrentar intempéries e resguardar intimidades, deixando mais fortes e protegidos os seus usuários,

associa-se ao processo de compartilhamento de conhecimento e o seu papel em partilhar poder, no que diz respeito ao empoderamento dos sujeitos.

A metáfora da festa nos faz pensar o processo de compartilhamento de saberes e de práticas como evento que antecede a chegada de um convidado e que continua com a saída do mesmo. Ela nos ensina a construir diálogos durante o compartilhamento, posicionando-se como um convidado a fazer convite ao outro a refletir sobre o cotidiano e, ao sair, deixa marcas e a sensação de poder voltar.

Finalmente, a metáfora existente na ideia de que o caminho que se faz ao caminhar coloca o processo de compartilhamento como um processo aberto 
a mudanças, e que se faz numa atitude ativa de criar as oportunidades para repartir. Essas ocasiões, como projetos de extensão, ações de pesquisa, cursos e rodas temáticas, não vêm prontas; são também construções sociais, que se fazem à medida que experimentamos cada momento e situação, a partir de nossas vivências, e nos colocamos em busca, na intenção de compreender as possibilidades presentes no contato com o outro.

Essas metáforas são, pois, imagens que nos ajudam a trilhar outros caminhos, primeiro em não se conformar com o que existe de permanência do velho modelo de atenção psiquiátrica e, segundo, simultaneamente a isto, agir na busca por criar oportunidades de compartilhamentos de saberes e de práticas em saúde mental e saúde da família; práticas constitutivas de novas realidades na produção do cuidado e operadoras no cotidiano para constituição de sujeitos coautores do que é ensinado e do que é aprendido. Faz também o processo ensino/aprendizagem dinâmico, inacabado, criativo para invenção ou descobertas de recursos de aprendizagem e de saberes e práticas inovadoras, e isso também são construções sociais. Assim, o caminho continua em cada oportunidade para descortinarmos horizontes mais amplos dessa trajetória e responsabilidade social. Quanto ao futuro? Este permanece intacto e convida você a participar, também, do processo. 


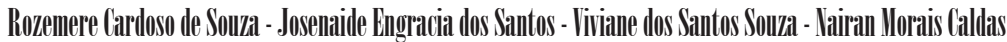

\section{Referências}

AYRES, J. R. C. M. Care and reconstruction in healthcare practices. Interface - Comunicação, Saúde, Educação, Botucatu, v.8, n.14, p.73-92, set. 2003/fev. 2004 .

ALCARÁ, A. R. et al. Fatores que influenciam o compartilhamento da informação e do conhecimento. Perspectivas em Ciência da Informação, v.14, n.1, p. 170-191, 2009. Trimestral.

CAMPOS, G. W. S. Um método para análise e co-gestão de coletivos. A constituição do sujeito, a produção de valor de uso e a democracia em instituições: o método da roda. São Paulo: Hucitec, 2000.

CAMPOS, G. S.; DOMITTI, A. C. Apoio matricial e equipe de referência: uma metodologia para a gestão do trabalho interdisciplinar. Cadernos de Saúde Pública, Rio de Janeiro, v. 23, n. 2, p. 399-407, fev. 2007.

CARVALHO, M. A. P.; ACIOLI, S.; STOTZ, E. N. O processo de Construção compartilhada do conhecimento. Uma experiência de investigação científica do ponto de vista popular. In: VASCONCELOS, E. M. (org.). A saúde nas palavras e nos gestos. Reflexões da rede educação popular e saúde. São Paulo: Hucitec, 2001.

COULON, A. A Escola de Chicago. Tradução Tomás R. Bueno. Campinas: Papyrus, 1995.

EVARISTO, P. Gestão da psiquiatria na comunidade. UNOPAR Científica: Ciências Biológicas e da Saúde, Londrina, v. 2, n. 1, p. 27-34, out. 2000. 
FAGUNDES, S.; HUBNER, A.; FISCHETTI, S.; ROTELLI, F.; CIPOLLA, A. Saúde mental nos SILOS: propostas operacionais. In: KALIL, M. E. X. (org). Saúde mental e cidadania no contexto dos sistemas locais de saúde. São Paulo: HUCITEC, 1992. (Coleção Saúde Loucura, v. 7).

FERREIRA, A. B. H. Minidicionário Aurélio. Rio de Janeiro: Editora Nova Fronteira, 1985.

FIGUEIREDO, M. D. Saúde mental na atenção básica: um estudo hermenêutico-narrativo sobre o apoio matricial na rede SUS - Campinas (SP). 2006. Dissertação (Mestrado em Saúde Coletiva)- Universidade Estadual de Campinas, Campinas, 2006.

FREIRE, P. Pedagogia da autonomia: saberes necessários à prática educativa. São Paulo: Paz e Terra, 1996.

Educação como prática da liberdade. Rio de Janeiro: Paz e Terra, 2003.

GADAMER, H. G. Verdad y método. Salamanca: Sígueme, 1991.

GRANDESSO, M. Sobre a reconstrução do significado: uma análise epistemológica e hermenêutica da prática clínica. São Paulo: Casa do Psicólogo, 2000.

\section{MICHAELIS. Moderno Dicionário da Língua Por-}

tuguesa. Uol, São Paulo, 2010. Disponível em: <http:// michaelis.uol.com.br/moderno/portugues/index.php $>$. Acesso em: 12 maio 2010.

MOURA, A. Linhas da diferença em psicopatologia. Salvador: Cian, 2007. 
PEARCE, N. B. Novos modelos e metáforas comunicacionais: a passagem da teoria à prática, do objetivismo ao construcionismo social e da representação à reflexividade. In: SCHNITMAN, D.F. (org). Novos paradigmas, cultura e subjetividade. Porto Alegre: Artes Médicas, 1996.

PITTA, A. Reorientação do modelo de atenção: equidade e justiça social na organização de serviços de saúde mental. In: BRASIL. Ministério da Saúde. Conselho Nacional de Saúde. Cadernos de Textos de Apoio da III Conferência Nacional de Saúde Mental. Brasília,DF: MS: CNS, 2001.

PRIBERAM. Dicionário Priberam da Língua Portuguesa. Priberam Informática, [S.l, 2010]. Disponível em: <http://www.priberam.pt/dlpo/consultar.aspx>. Acesso em: 12 maio 2010.

RABELO, M. C. M. A experiência de indivíduos com problema mental: entendendo projetos e sua realização. In: RABELO, M. C.; ALVES, P. C. B.; SOUZA, I. Experiência de doença e narrativa. Rio de Janeiro: FIOCRUZ, 1999.

SPINK, M. J. (org.). Práticas discursivas e produção de sentidos no cotidiano: aproximações teóricas e metodológicas. São Paulo: Cortez, 1999.

TÓFOLI, L. F. F. Desafios e estratégias de inserção da saúde mental na atenção básica. In: SIMPÓSIO DE SAÚDE MENTAL DA UESC, 2., 2010, Ilhéus. Anais ... Ilhéus: Uesc, 2010. 1 CD-ROM. Windows 2010. p. 1. (Palestra proferida em 7 de maio de 2010). 


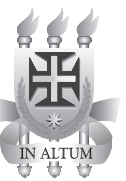

IMPRENSA UNIVERSITÁRIA

Impresso na gráfica da Universidade Estadual de SANta CruZ - Ilhéus-BA 